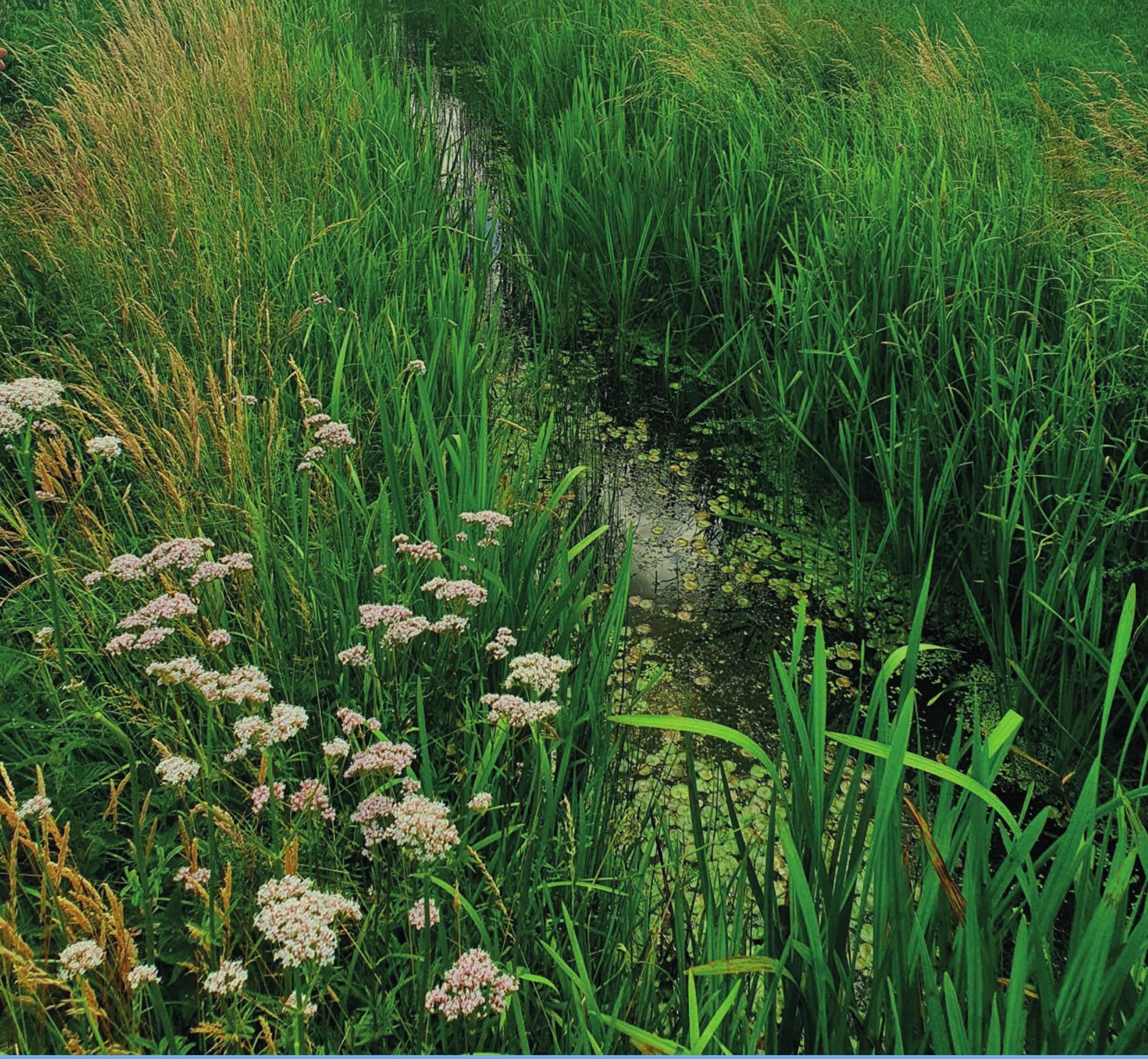

\title{
Systematiek classificeren habitatkwaliteit agrarisch gebied ten behoeve van het ANLb
}

Tim Visser en Dick Melman 



\section{Systematiek classificeren habitatkwaliteit agrarisch gebied ten behoeve van het ANLb}

Tim Visser ${ }^{1}$ en Dick Melman ${ }^{1}$

Met medewerking van: Rémon ten Harmsel ${ }^{2}$, Dennis Maas ${ }^{3}$, Jochem Sloothaak ${ }^{4}$, Sander Moonen ${ }^{1,}$ Ralph Buij $^{1}$ en André de Bonte ${ }^{5}$

1 WUR

2 RAVON

3 Maas-Arend

4 Brabants Landschap

5 Landschap Overijssel

Dit onderzoek is uitgevoerd door Wageningen Environmental Research in opdracht van en gefinancierd door het ministerie van Landbouw, Natuur en Voedselkwaliteit, in het kader van het Beleidsondersteunend onderzoekthema 'Duurzame voedselvoorziening \& -productieketens \& Natuur' (BO-43-023.01-006).

Wageningen Environmental Research

Wageningen, juni 2020

Gereviewd door:

Bart de Knegt, onderzoeker (Wageningen Environmental Research)

Akkoord voor publicatie:

Marion Kluivers-Poodt, teamleider team dierecologie

Rapport 3018

ISSN 1566-7197 
Visser, T. en Th.C.P. Melman, 2020. Systematiek classificeren habitatkwaliteit agrarisch gebied ten behoeve van het ANLb. Wageningen, Wageningen Environmental Research, Rapport 3018.68 blz.; 0 fig.; 1 tab.; 140 ref.

Met agrarisch natuurbeheer (regeling ANLb) wordt gewerkt aan de verbetering van de staat van instandhouding van doelsoorten. Met agrarisch natuurbeheer wordt verbetering van de habitatkwaliteit nagestreefd. In dit project is voor de vier leefgebiedtypen die binnen het ANLb worden onderscheiden aan de hand van gidssoorten een systematiek ontwikkeld om de habitatkwaliteit vast te stellen. Per gidssoort zijn de belangrijke habitateisen in beeld gebracht. Vervolgens zijn de bottleneckfactoren benoemd die in de huidige omstandigheden het knelpunt vormen voor het duurzaam voortbestaan. Voor de belangrijkste habitateisen is beschreven hoe deze kunnen worden gemeten in het veld of op basis van bestaand kaartmateriaal.

De scores voor de habitatfactoren zijn geobjectiveerd en per factor is aangegeven hoe deze kan worden vastgesteld (type waarnemingen en ruimtelijk niveau). Met behulp van een klasse-indeling worden deze waarden voorlopig uitgedrukt in 'onvoldoende/slecht', 'matig', 'goed' en 'zeer goed'. Deze termen geven daarmee automatisch aan waar verbeteropgaven liggen.

De ontwikkelde systematiek is voorlopig, omdat er nog veel kennishiaten zijn. Deze onderkende hiaten kunnen worden gebruikt om nieuwe kennis te verzamelen. De ontwikkelde systematiek levert een bijdrage aan één taal en begrippenset voor het agrarisch natuurbeheer. Zij kan voor collectieven input geven om onderling van elkaar te leren: vergelijking van habitatkwaliteit en geleverde inspanningen aan het beheer en de ontwikkeling van de doelsoorten.

Aanbevolen wordt deze systematiek in de praktijk te gaan uitproberen, onderzoekers samen met collectieven. Daarbij kan inzicht worden verkregen of een en ander herkenbaar is en stimuleert tot verbeteringen in het ANLb.

Agri environmental schemes (the 'ANLb scheme' in Dutch) are implemented in order to conserve specific target species that are highly dependent on the agricultural landscape. In its core, these schemes are designed to improve habitat quality. In this project, we developed a methodology that can be used to identify the habitat quality for a certain species in a specific area, in order to identify which improvements with regards to the management could be made. First, the habitat requirements of 8 species were collected based on a literature review. Subsequently, the bottlenecks for conservation were identified. Finally, we developed a methodology for each habitat requirement with guidelines on how these habitat factors could be measured for a certain area. The system developed is work in progress, and enabled us to identify important knowledge gaps.

The system contributes to the development of a shared language with regards to habitat requirements of target species. It can be a helpful tool to learn from each other by comparing the efforts with regards to the management implemented, the habitat quality it resulted in and ultimately the conservation status of the target species. It is recommended to try this methodology in practice, in order to gain sight on the pros and cons of this method.

Trefwoorden: agrarisch natuurbeheer, habitatkwaliteit, gidssoorten, bottleneckfactoren, methodiek, praktijkhandleiding

Dit rapport is gratis te downloaden van https://doi.org/10.18174/524220 of op

www.wur.nl/environmental-research (ga naar 'Wageningen Environmental Research' in de grijze balk onderaan). Wageningen Environmental Research verstrekt geen gedrukte exemplaren van rapporten. 
2020 Wageningen Environmental Research (instituut binnen de rechtspersoon Stichting Wageningen Research), Postbus 47, 6700 AA Wageningen, T 03174807 00,

www.wur.nl/environmental-research. Wageningen Environmental Research is onderdeel van Wageningen University \& Research.

- Overname, verveelvoudiging of openbaarmaking van deze uitgave is toegestaan mits met duidelijke bronvermelding.

- Overname, verveelvoudiging of openbaarmaking is niet toegestaan voor commerciële doeleinden en/of geldelijk gewin.

- Overname, verveelvoudiging of openbaarmaking is niet toegestaan voor die gedeelten van deze uitgave waarvan duidelijk is dat de auteursrechten liggen bij derden en/of zijn voorbehouden.

Wageningen Environmental Research aanvaardt geen aansprakelijkheid voor eventuele schade voortvloeiend uit het gebruik van de resultaten van dit onderzoek of de toepassing van de adviezen.

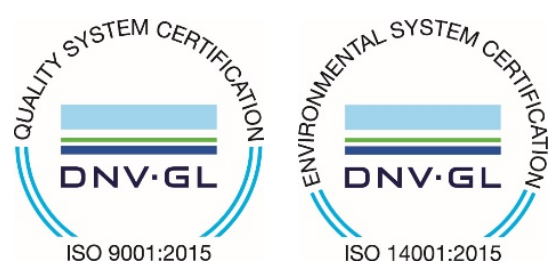

Wageningen Environmental Research werkt sinds 2003 met een ISO 9001 gecertificeerd kwaliteitsmanagementsysteem.

In 2006 heeft Wageningen Environmental Research een milieuzorgsysteem geïmplementeerd, gecertificeerd volgens de norm ISO 14001.

Wageningen Environmental Research geeft via ISO 26000 invulling aan haar maatschappelijke verantwoordelijkheid.

Wageningen Environmental Research Rapport 3018 | ISSN 1566-7197

Foto omslag: Tim Visser 



\section{Inhoud}

$\begin{array}{ll}\text { Verantwoording } & 7\end{array}$

$\begin{array}{ll}\text { Samenvatting } & 9\end{array}$

1

Inleiding

11

2

$\begin{array}{ll}\text { Materiaal en methoden } & 12\end{array}$

2.1 Keuze gidssoorten $\quad 12$

2.2 Beschrijving ecologie 12

2.2.1 Habitateisen 12

2.2.2 Bottleneckfactoren $\quad 12$

2.3 Classificatiesystematiek habitatkwaliteit 13

2.3.1 Ontwikkeling 13

$\begin{array}{ll}2.3 .2 \text { Draagvlak } & 15\end{array}$

3

$\begin{array}{ll}\text { Resultaten } & 16\end{array}$

3.1 Grutto - gidssoort open grasland $\quad 16$

3.2 Ringmus - gidssoort droge dooradering 23

$\begin{array}{lll}3.3 & \text { Veldleeuwerik - gidssoort open akkerland } & 28\end{array}$

3.4 Patrijs - gidssoort droge dooradering/open akkerland $\quad 35$

3.5 Grote modderkruiper - gidssoort natte dooradering $\quad 40$

$\begin{array}{lll}3.6 & \text { Bittervoorn - gidssoort natte dooradering } & 44\end{array}$

3.7 Torenvalk - Gidssoort open grasland \& open akkerland $\quad 48$

$4 \quad$ Discussie $r 52$

$5 \quad$ Conclusie en aanbevelingen $\quad 54$

$\begin{array}{ll}\text { Literatuur } & 55\end{array}$

$\begin{array}{lll}\text { Bijlage } 1 & \text { Totstandkoming kaartbeelden } & 62\end{array}$ 



\section{Verantwoording}

Rapport: 3018

Projectnummer: 5200045284

Wageningen Environmental Research (WENR) hecht grote waarde aan de kwaliteit van zijn eindproducten. Een review van de rapporten op wetenschappelijke kwaliteit door een referent maakt standaard onderdeel uit van ons kwaliteitsbeleid.

Akkoord Referent die het rapport heeft beoordeeld,

functie: $\quad$ onderzoeker (Wageningen Environmental Research)

naam: Bart de Knegt

datum: mei 2020

Akkoord teamleider voor de inhoud,

naam: Marion Kluivers-Poodt

datum: juni 2020 


\section{Samenvatting}

Het ANLb richt zich op het behoud en de versterking van een groot aantal doelsoorten waarvoor het landbouwgebied een substantieel deel van de habitat vormt. Verbetering van de habitat door beheer vormt de laatste, maar essentiële stap in de keten van activiteiten (van beleidsvorming tot organisatievorming, naar beheerplannen en ten slotte uitvoering van beheer) die voor het ANLb relevant zijn.

In dit project staat de habitatkwaliteit centraal. Voor de vier leefgebiedtypen die binnen het ANLb worden onderscheiden, is aan de hand van één of enkele gidssoorten de habitatkwaliteitssystematiek uitgewerkt. Per soort zijn de ecologische randvoorwaarden van de habitat in beeld gebracht. Vervolgens zijn de bottleneckfactoren benoemd die in de huidige omstandigheden het knelpunt vormen voor het duurzaam voortbestaan. Aan deze bottleneckfactoren zou door middel van het agrarisch natuurbeheer moeten worden gewerkt om tot verbetering van de habitat te komen.

Het uiteindelijke doel is dat collectieven met behulp van deze systematiek hun gebieden kunnen bekijken en vaststellen waar de prioritaire verbeterpunten liggen. Om dit hanteerbaar te krijgen, zijn voor de relevantste habitatfactoren klassen onderscheiden. De scores voor de habitatfactoren zijn geobjectiveerd en per factor is aangegeven hoe deze kan worden vastgesteld (type waarnemingen en ruimtelijk niveau). Met behulp van de klasse-indeling worden deze waarden uitgedrukt in 'onvoldoende/slecht', 'matig', 'goed' en 'uitstekend'. Deze termen geven daarmee automatisch aan waar verbeteropgaven liggen.

De kennis over de diverse doelsoorten loopt sterk uiteen. Dat betreft zowel de informatie over het belang van de verschillende habitatfactoren, de grenswaarden die daarbij gelden en de ruimtelijke eisen die eraan worden gesteld. Dit geldt ook voor de integratie van de verschillende factoren om tot een eenduidig eindbeeld te komen voor de habitat als totaal. Hoe moeten de verschillende factoren ten opzichte van elkaar worden gewogen en in hoeverre treedt er interactie op (en kan een tekort van de ene factor worden gecompenseerd met een surplus van de andere)? Zo is er voor de soorten van het open grasland (met name weidevogels) al veel meer bekend dan voor de soorten van de droge dooradering. De ontwikkelde systematiek helpt duidelijk maken waar kennishiaten spelen en kan ook worden gebruikt om gericht aan het oplossen van dergelijke kennishiaten te gaan werken.

Een ander belangrijk aspect van de ontwikkelde systematiek is dat het een goede input kan vormen voor collectieven om met elkaar in gesprek te gaan over de kwaliteit van hun leefgebiedtypen en het door hen ingezette beheer. De systematiek is een bijdrage aan het creëren van één taal en één begrippenset voor het agrarisch natuurbeheer.

Als vervolg zou de hier ontwikkelde systematiek in de praktijk kunnen worden uitgeprobeerd, onderzoekers samen met de collectieven. Daartoe zal een praktische handleiding moeten worden opgesteld hoe de habitatkwaliteit kan worden vastgesteld. Onderzocht kan worden of die scores voldoende nauwkeurig en betrouwbaar zijn (en niet afhankelijk van degene die de meting uitvoert). Vervolgens kan worden besproken in hoeverre de scores door onderzoekers en collectieven worden herkend en gedragen en of ze handvaten vormen om de kwaliteit en effectiviteit van het agrarisch natuurbeheer te vergroten. Habitatkwaliteit, dat is waar het in het agrarisch natuurbeheer uiteindelijk om draait! 


\section{$1 \quad$ Inleiding}

\section{Aanleiding \& doelstelling}

Het ANLb richt zich op het behoud en de versterking van een groot aantal doelsoorten waarvoor het landbouwgebied een substantieel deel van het leefgebied vormt. Hier wordt aan gewerkt door beheerpakketten af te sluiten die de beoogde doelsoorten ten goede moeten komen. Monitoring van de resultaten is in de grote meerderheid van de gevallen gericht op het monitoren van de populaties: gaan de doelsoorten voor- of achteruit? Dit levert essentiële informatie op over de ontwikkeling van de populaties van de verschillende doelsoorten.

Het sturende mechanisme achter de trends van deze populaties - de habitatkwaliteit die het resultaat is van het gevoerde beheer - blijft echter veelal buiten beschouwing. Uiteraard wordt wel gecontroleerd of men zich houdt aan de vastgestelde afspraken met betrekking tot het beheer, maar of de combinatie van het beheer en de lokale omstandigheden leiden tot een geschikte habitat voor de beoogde doelsoorten wordt niet systematisch gemonitord. Dit project heeft als doel een systematiek te ontwikkelen waarmee de habitatkwaliteit systematisch kan worden gemonitord.

\section{Urgentie}

Het monitoren van de habitatkwaliteit is belangrijk, omdat beheerpakketten niet per definitie resulteren in geschikte habitat. Dit kwam onder andere aan het licht in onderzoek naar de effecten van greppelplasdraspercelen op de overleving van kievitkuikens (Melman et al., 2020). Daaruit bleek dat plasdraspercelen niet leiden tot de gewenste verbetering van de kuikenoverleving van de kievit. De auteurs stelden vast dat het uitblijven van een positief effect mogelijk samenhangt met het uitblijven van een aanzienlijke verbetering van de habitatkwaliteit: de vegetatie bleek op een meerderheid van de plasdraspercelen zeer gesloten en structuurarm te zijn. Het gevoerde beheer (netjes volgens de beheervoorschriften) resulteerde dus niet in alle gevallen in een optimale habitat. Er zijn tal van dergelijke voorbeelden. Denk hierbij bijvoorbeeld aan percelen met uitgestelde maai-datum die stranden in het dominante stadium (dominantie door één enkele soort, bijvoorbeeld gestreepte witbol): het beheer wordt geheel volgens de geldende beheervoorschriften uitgevoerd, maar het resultaat is niet optimale habitat.

Positieve effecten op populatieniveau kunnen (afhankelijk van de soort) vijf tot vijftien jaar in beslag nemen. Positieve effecten van het gevoerde beheer op de habitatkwaliteit gaan daaraan vooraf. Door de habitatkwaliteit te monitoren, komen discrepanties tussen het beoogde en het behaalde resultaat eerder voor het voetlicht, waardoor tijdig kan worden bijgestuurd. Bovendien kan het monitoren van de habitatkwaliteit bijdragen aan de ontwikkeling van één taal en één begrippenset, wat kennisuitwisseling tussen collectieven kan bevorderen.

\section{Doelstelling}

Dit project heeft als doel een systematiek te ontwikkelen waarmee de habitatkwaliteit van een gebied voor een specifieke soort kan worden vastgesteld. Zo'n systematiek is nog niet beschikbaar. Met behulp van deze systematiek dient het mogelijk te zijn om voor de verschillende leefgebiedtypen (open grasland, open akkers, droge dooradering en natte dooradering en eventueel water) de kwaliteit van de habitat te classificeren, met speciale aandacht voor de doelsoorten van het ANLb. Een belangrijk aspect is dat de methodiek op dusdanige wijze wordt ontwikkeld dat deze ook op de langere termijn kan worden gebruikt bij het evalueren van het ANLb. Het achterliggende doel is om de ecologische effectiviteit van het ANLb te maximaliseren.

De te ontwikkelen systematiek dient:

a. Hanteerbaar te zijn in de praktijk;

b. Bruikbaar te zijn op de lange termijn (t.b.v. eenvormigheid van toekomstige ANLb-evaluaties);

c. Ondersteund te worden door de relevante actoren (met name BoerenNatuur en daarmee verbonden collectieven; LandschappenNL, als vrijwilligersorganisatie die nauw bij de monitoring van het agrarisch natuurbeheer is betrokken; Provincies en BIJ12 als verantwoordelijken voor en uitvoerders van het ANLb). 


\section{Materiaal en methoden}

\section{$2.1 \quad$ Keuze gidssoorten}

Habitatkwaliteit is soortspecifiek. Elke soort stelt andere eisen en in sommige gevallen zijn deze eisen zelfs strijdig. Het is daarom niet mogelijk om voor de vier leefgebiedtypen generiek de habitatkwaliteit te beschrijven. Dat kan in eerste aanleg het beste door gidssoorten te kiezen. De gidssoorten zijn op vlak van de volgende factoren gekozen:

- Representativiteit leefgebiedtype: gekozen voor soorten die representatief zijn voor het betreffende leefgebiedtype (bijvoorbeeld grutto bij open grasland).

- Beschikbaarheid literatuur: soorten waarvoor onvoldoende (betrouwbare) informatie beschikbaar is, zijn niet in de selectie opgenomen.

Het resultaat van de selectie is weergegeven in Tabel 1.

Tabel 1 Geselecteerde gidssoorten per leefgebiedtype.

\begin{tabular}{ll} 
Leefgebiedtype & Gidssoort \\
Grasland & Grutto, torenvalk \\
\hline Open akker & Veldleeuwerik, torenvalk, patrijs \\
\hline Droge dooradering & Ringmus, patrijs \\
\hline Natte dooradering & Grote modderkruiper, bittervoorn
\end{tabular}

\subsection{Beschrijving ecologie}

\subsubsection{Habitateisen}

Voor iedere gidssoort is een literatuurstudie uitgevoerd om de habitateisen van de betreffende soort in beeld te brengen. Hierbij is getracht om onderscheid te maken tussen algemene habitateisen die op meerdere levensfuncties aangrijpen en habitateisen die van belang zijn voor een specifieke levensfunctie (reproductie, foerageren, overwinteren, schuilen). De belangrijkste habitateisen zijn in de tekst (hoofdstuk 3) herkenbaar aan de groene tekstkleur. Habitateisen die op deze wijze zijn gemarkeerd, maken onderdeel uit van de set aan habitateisen waar een gebied op wordt getoetst.

\subsubsection{Bottleneckfactoren}

Binnen de reeds genoemde literatuurstudie is tevens aandacht besteed aan het identificeren van de bottleneckfactoren voor het behoud van de gidssoorten. Bottleneckfactoren zijn knelpunten voor instandhouding van de soort in kwestie. De bottleneckfactoren grijpen in de meeste gevallen terug op de habitateisen. In feite vormen de bottleneckfactoren tezamen een beschrijving van 'de habitateisen waar momenteel onvoldoende aan wordt voldaan'. 


\subsection{Classificatiesystematiek habitatkwaliteit}

\subsubsection{Ontwikkeling}

Bij de ontwikkeling van de classificatiesystematiek is voor iedere soort bepaald:

1. Welke habitateisen onderdeel uitmaken van de classificatiesystematiek en dus daadwerkelijk dienen te worden gemeten;

2. Op welk schaalniveau het eindoordeel m.b.t. De habitatkwaliteit plaatsvindt;

3. Welke habitateisen op gebiedsniveau en welke op kleinere schaal (erf/perceel) dienen te worden gemeten;

4. Welke kwaliteitsklassen kunnen worden gekoppeld aan elk van de habitatfactoren;

5. Met welke methodiek de habitateis kan worden gemeten;

6. Op welke wijze de scores op het niveau van de losse habitateisen kunnen worden geïntegreerd tot een eindoordeel.

\section{Keuze habitatfactoren}

De meeste soorten stellen een groot aantal eisen aan hun habitat. Na de literatuurstudie (zie paragraaf 2.2) is bepaald welke habitateisen onderdeel moeten uitmaken van de classificatiesystematiek en dus daadwerkelijk moeten worden gemeten. Bij de selectie zijn de volgende aspecten in acht genomen:

- Alle habitateisen die een bottleneck vormen voor behoud van de soort dienen onderdeel uit te maken van de classificatiesystematiek. Dit zijn de factoren die de omvang van de lokale populatie beperken en dus de 'knoppen' waar je als beheerder aan kunt draaien om de soort te bevorderen.

- Waar mogelijk wordt gekozen voor de habitateisen die tezamen een beeld geven van een groot aantal 'onderliggende habitateisen'. Zo geldt voor de grutto dat de bodemvochtigheid medebepalend is voor de inprikbaarheid van de bodem, de bereikbaarheid van het bodemleven, de gewasgroei en de insectenrijkdom. Het bepalen van de inprikbaarheid van de bodem, de bereikbaarheid van het bodemleven en vele andere aspecten van de habitat zou praktisch niet uitvoerbaar zijn. Het meten van overkoepelende habitateisen heeft om deze reden de voorkeur, zolang deze factoren tezamen een representatief beeld geven van de staat van de habitat.

- Habitatfactoren die relevant zijn buiten de periode dat de soort zich in Nederland bevindt, zijn niet opgenomen in de classificatiesystematiek.

\section{Schaalniveau eindoordeel habitatkwaliteit}

Het eindoordeel over de habitatkwaliteit vindt op gebiedsniveau plaats. De grenzen van het 'gebied' dienen waar mogelijk te worden afgestemd op het functioneren van de lokale populatie. Voor weidevogels wordt al geruime tijd gebruikgemaakt van zogenoemde 'weidevogelvakken' voor het uitvoeren van de tellingen van nesten en gezinnen. De grenzen van deze weidevogelvakken worden gevormd door onneembare barrières voor weidevogelgezinnen. De kuikens kunnen de eerste weken na de geboorte nog niet vliegen; diepe vaarten en snelwegen vormen daarom onneembare barrières. Voor weidevogels ligt het voor de hand om bij het bepalen van de habitatkwaliteit gebruik te maken van de gebiedsgrenzen van weidevogelvakken, aangezien de lokale weidevogelpopulatie dient te functioneren binnen de grenzen van het weidevogelvak. Een bijkomend voordeel is dat voor een groot deel van Nederland deze begrenzingen reeds bestaan en worden gebruikt door de collectieven. Wat betreft vogels lijkt deze aanpak ook goed bruikbaar voor andere soorten nestvlieders, waaronder de patrijs. Ook voor vissen is in veel gevallen sprake van sterke, ruimtelijke barrières die duidelijke aanknopingspunten vormen voor het bepalen van de begrenzing.

Voor de overige soorten is het bepalen van de begrenzing van het gebied waarvoor de habitatkwaliteit dient te worden vastgesteld lastig. Dit omdat er in veel gevallen geen sprake is van sterke ruimtelijke barrières tijdens een van de levensfases. Denk hierbij bijvoorbeeld aan de ringmus en veldleeuwerik: de jongen worden door de ouders gevoed tot het stadium waarin zij zelf in staat zijn te vliegen. Er is voor deze soort dus geen sprake van onneembare barrières tijdens de reproductiefase. Landschappelijke lijnstructuren, zoals snelwegen en kanalen, vormen voor deze soorten vanuit ecologisch oogpunt geen logisch handvat voor het bepalen van de begrenzing. 
Idealiter worden de grenzen van het gebied zodanig gekozen dat zij relevant zijn voor het functioneren van een lokale populatie. Er zijn meerdere aspecten die hierbij een rol kunnen spelen en mogelijkerwijs handvaten bieden bij het bepalen van de begrenzing. Het meest voor de hand liggende betreft de actieradius van de soort in kwestie (de afstand waarover de soort zich voor zijn 'dagelijkse bezigheden' verplaatst). In het geval de actieradius van een soort bekend is, kan ervoor worden gekozen om habitatcomponenten die binnen deze afstand van elkaar liggen als een eenheid te beschouwen. Zo kan een netwerk aan houtwallen, erven, akkerranden en overige habitatelementen binnen een bepaalde afstand van elkaar tezamen de begrenzing van een gebied vormen. Met betrekking tot deze aanpak is er een aantal aandachtspunten: ten eerste is er weinig bekend over de actieradius van de verschillende soorten. Wel bestaan er inschattingen (expert judgement) op grond van opgedane ervaring/observaties. Ten tweede wordt het bepalen van de begrenzing bemoeilijkt door het feit dat de ruimtelijke rangschikking van de componenten ook een rol speelt. Dit kan worden geillustreerd met het volgende: soort A heeft een actieradius van $300 \mathrm{~m}$. In een bepaald gebied zijn twee duidelijke kernen te herkennen, bestaande uit een cluster van habitatcomponenten in nabijheid van elkaar (bv. $\pm 50 \mathrm{~m}$ van elkaar). Beide kernen liggen $500 \mathrm{~m}$ bij elkaar vandaan. Hiertussen bevindt zich een habitatcomponent op $\pm 250 \mathrm{~m}$ afstand van beide kernen. De vraag is of de genoemde kernen als een eenheid dienen te worden beschouwd of niet. De genoemde afstand van $250 \mathrm{~m}$ valt binnen de actieradius van de soort. Vormt een enkele 'stapsteen' tussen twee gebieden voldoende aanleiding om beide kernen als een eenheid te beschouwen? Zo niet, waar ligt dan wel de grens?

Vanwege bovenstaande complicaties wordt er voorlopig voor gekozen om voor de overige soorten te kiezen voor een begrenzing die is gebaseerd op grond van:

- Indicaties van de actieradius van de soort;

- Actoren: bijvoorbeeld een werk- of telgebied van een bepaald collectief;

- Topografische eenheid: gebieden die om uiteenlopende redenen als een eenheid worden beschouwd, vanwege landschappelijke kenmerken, historie, cultuur etc.

\section{Schaalniveau waarop metingen plaatsvinden}

Zoals gezegd, wordt de uitspraak over de habitatkwaliteit op gebiedsniveau gedaan. Voor sommige factoren geldt dat ze uitsluitend op gebiedsniveau adequaat kunnen worden vastgesteld (denk bijvoorbeeld aan de openheid van het landschap of het percentage dekking van een bepaalde beheervorm).

Andere habitatfactoren dienen steekproefsgewijs worden vastgesteld. Afhankelijk van de soort/het leefgebiedstype wordt dit gedaan bijvoorbeeld op het niveau van een perceel (kruidenrijkdom vegetatie), erf (nestgelegenheid ringmus) of sloot (bedekking aquatische vegetatie). Binnen dit project worden deze metingen 'elementmetingen' genoemd. Om een representatief beeld te verkrijgen op gebiedsniveau, dienen voldoende elementmetingen te worden uitgevoerd. De invulling van het benodigd aantal metingen en het selecteren van de locaties voor elementmetingen zal in een vervolgproject opgepakt moeten worden.

\section{Vaststellen kwaliteit per habitatfactor}

Voor iedere (gids)soort zijn per habitatfactor de eisen geïdentificeerd (zie paragraaf 2.2.1). Deze habitateisen voeden tezamen de eindbeoordeling van de habitatkwaliteit op gebiedsniveau. Aan iedere habitateis zijn vier kwaliteitsklassen gekoppeld (zeer goed, goed, matig, slecht), waarvoor de (voorlopige) grenswaarden zijn bepaald.

\section{Meetmethode}

In alle gevallen wordt beoogd om eerst de absolute, feitelijke waarde vast te leggen en op basis daarvan de kwaliteitsklasse waar deze waarde toe behoort. Daarmee ontstaat ruimte om de grenswaarden van de kwaliteitsklasse later te herzien op grond van nieuwe inzichten. Bij de garing van gegevens wordt als het maar even kan gebruikgemaakt van bestaande datasets, mits de daarvoor gehanteerde meetmethode adequaat is, voldoende actueel is en op het juiste ruimtelijke niveau wordt toegepast. 


\section{Eindoordeel op geëigende ruimtelijk niveau}

De hierboven beschreven aanpak resulteert in een uitspraak over de kwaliteit van een gebied op het vlak van de verschillende habitateisen (openheid in gebied X scoort 'zeer goed', kruidenrijkdom in gebied x scoort 'matig' etc.). Een einduitspraak over de habitatkwaliteit van een bepaald gebied komt idealiter tot stand door een integratie van de afzonderlijke scores op het vlak van alle habitateisen. Bij het integreren van de scores speelt een aantal aspecten een rol.

Welke habitateisen zijn randvoorwaardelijk voor het voorkomen van de soort? In sommige gevallen is sprake van een sterke randvoorwaardelijkheid. Denk hierbij bijvoorbeeld aan nestgelegenheid voor de ringmus. In het geval er geen nestelmogelijkheden zijn, doet de score op vlak van andere factoren er niet toe: het gebied is niet geschikt als leefgebied. Wat is het relatieve belang van de habitatfactoren? De overige, niet-randvoorwaardelijke habitateisen zijn in de meeste gevallen niet in gelijke mate van belang voor de habitatkwaliteit.

De antwoorden op bovenstaande vragen zijn voor de meeste soorten nog niet af te leiden uit de literatuur. In enkele gevallen zijn studies uitgevoerd waarbij de resultaten van een multifactorenanalyse inzicht geven in het relatieve belang van de verschillende habitateisen (bijvoorbeeld voor weidevogels). Voor een grote meerderheid van de soorten geldt dat deze kennis ontbreekt en dat zal moeten worden teruggevallen op expert judgement. In een aantal gevallen zal de ecologische kennis niet toereikend zijn om tot een volledige beoordeling van de habitat te komen en zal vooralsnog moeten worden volstaan met een partiële beoordeling. Signalering van dergelijke kennishiaten kunnen aanleiding zijn voor verder onderzoek.

\subsubsection{Draagvlak}

Bij het ontwikkelen van de habitatkwaliteitssystematiek is draagvlak bij de beoogde gebruikers essentieel. Gedurende het uitvoeringstraject is enkele malen met BoerenNatuur overlegd. In deze contacten werd het gesprek over nut en noodzaak van een systematische beoordeling van de habitatkwaliteit geopend. Tevens kwam de relatie daarvan met het (agrarisch natuur)beheer aan de orde. In deze gesprekken werd gewerkt aan het opbouwen van draagvlak voor deze benadering en werd zicht gekregen op eventuele gevoelige aspecten daarin. In eerste instantie zijn de contacten gelegd met BoerenNatuur. In samenspraak met en op instigatie van BoerenNatuur zijn de contacten verbreed naar de vorig jaar ingestelde Kenniskringen van de vier leefgebiedtypen, waarin de beheercollectieven hun ideeën en kennisbehoeftes ontwikkelen. Daartoe zijn er diverse overleggen met BoerenNatuur geweest, is een presentatie verzorgd op de BoerenNatuurdag in het voorjaar en zijn er workshops gehouden op een landelijke dag van de kenniskringen. 


\section{Resultaten}

Leeswijzer

Hieronder volgt een uitwerking per soort. Voor iedere soort worden stapsgewijs de volgende zaken beschreven:

1. Habitateisen

Uitgewerkt naar algemene habitateisen die op meerdere levensfuncties aangrijpen en habitateisen die uniek zijn voor een specifieke levensfunctie: reproductie, foerageren, schuilen, overwinteren. De belangrijkste habitateisen zijn te herkennen aan de groene tekstkleur.

\section{Bottleneckfactoren}

Knelpunten voor instandhouding. Grijpen terug op habitateisen. In feite een beschrijving van 'de habitateisen waar momenteel onvoldoende aan wordt voldaan'.

\section{Systematiek classificatie habitatkwaliteit}

Beschrijving van de wijze waarop de habitateisen kunnen worden gemeten in het veld dan wel op basis van bestaand kaartmateriaal. Het gaat hierbij vooral om de beschrijving van hoe de habitateisen kunnen worden gemeten en op welk ruimtelijk schaalniveau (gebiedsniveau of elementniveau). Instructies met betrekking tot de frequentie, het selecteren van locaties voor elementmetingen zullen worden uitgewerkt in een vervolg.

\subsection{Grutto - gidssoort open grasland}

\section{Habitateisen}

\section{Algemeen}

Voor de grutto geldt dat de meeste habitatfactoren relevant zijn gedurende meerdere levensstadia (reproductie, foerageren (adulten \& kuikens)). Het gaat hierbij om de volgende factoren:

- De grutto prefereert gebieden met een grote landschappelijke openheid. Besloten landschappen met veel opgaande structuren (bebouwing, bomenrijen en hoogspanningsmasten) worden door de grutto vermeden of in lagere dichtheden bezet, aangezien deze worden geassocieerd met de aanwezigheid van predatoren (Schekkerman et al., 2008; Van der Vliet et al., 2008).

- Er dienen zo min mogelijk verstorende elementen aanwezig te zijn in het landschap (wegen, spoorbanen, fiets- en wandelpaden, solitaire bomen, bebouwing etc.). Verstorende elementen worden door grutto's gemeden. In onderzoek van Kleijn et al. (2009) en Bruinzeel et al. (2011) is vastgesteld dat de dichtheid aan nesten lager is in nabijheid van verstorende bronnen. Hierbij dient te worden opgemerkt dat: (1) de mate waarin een verstorend effect optreedt afhankelijk is van de bron, (2) het verstorende effect afneemt naarmate de afstand ten opzichte van de bron toeneemt en (3) de grutto en tureluur tot de gevoelige soorten behoren, terwijl de kievit - en vooral de scholekster - minder gevoelig is voor verstoring.

Foerageren - adulten

Adulte grutto's zijn bodemtasters; ze gebruiken hun lange snavel om wormen, emelten en ander bodemleven te vinden. Een hoge bodemvochtigheid is bevorderlijk voor het foerageersucces van adulte grutto's. Een hoge bodemvochtigheid verlaagt namelijk de indringingsweerstand, waardoor de grutto in staat is zijn snavel (diep) in de bodem te brengen. Daarnaast zorgt een hoge bodemvochtigheid ervoor dat het bodemleven zich ophoudt in de bovenste laag van de bodem, waar het binnen het bereik van de grutto valt.

Naast graslanden met een hoge bodemvochtigheid foerageren adulte grutto's ook op zogenoemde plasdraslocaties. Plasdraslocaties betreffen locaties met een ondiepe laag water. In veel gevallen worden dergelijke percelen niet meer gebruikt voor agrarische doeleinden. Vooral in het voorjaar - als de grutto 
terugkomt uit het overwinteringsgebied - worden grootschalige plasdrassen gebruikt om op te vetten. Het is van belang dat de volwassen grutto's met een goede conditie aan het broedseizoen beginnen. Onderzoek heeft aangetoond dat de kuikenoverleving gerelateerd is aan onder meer de conditie van de oudervogels (Heygi \& Sasvari, 1998). Daarbij is de aanwezigheid van plasdras-locaties en/of voldoende graslanden met een hoge bodemvochtigheid in het gebied van groot belang.

Naast de meerwaarde als foerageergebied vervullen plasdraslocaties een belangrijke functie als rusten slaapplaats, zowel voor adulte grutto's in het vroege voorjaar (bij het opvetten na terugkomst uit het zuiden) als voor vliegvlugge juveniele vogels aan het einde van het broedseizoen ter voorbereiding van de nazomertrek.

\section{Foerageren - kuikens}

In tegenstelling tot juveniele en adulte vogels, die voornamelijk wormen en emelten eten, bestaat het dieet van de kuikens hoofdzakelijk uit grote, vliegende insecten (Schekkerman \& Beintema, 2007). Een grote insectenrijkdom is daarom essentieel. Daarenboven is de bereikbaarheid van deze insecten van groot belang (Kleijn et al., 2007; Kruk et al., 1997; Schekkerman \& Beintema, 2008). De bereikbaarheid (= de mate waarin kuikens in staat zijn om de insecten te vangen) is grotendeels afhankelijk van de hoogte en dichtheid van de vegetatie. Een hoge dichtheid van de vegetatie maakt het voor de kuikens onmogelijk om zich een weg te banen door de vegetatie, om al voortbewegend insecten te kunnen vangen.

Om deze redenen vormen extensief beheerde graslanden optimale foerageerhabitat voor de kuikens. Dergelijke graslanden worden gekenmerkt door een lage gewasdichtheid en een hoge kruidenrijkdom en door een grote variatie aan structuren en hoogtes, zowel in ruimte als tijd. Als aan deze kenmerken wordt voldaan, is te allen tijde geschikte foerageerhabitat beschikbaar voor de kuikens, waar de insecten aanwezig én bereikbaar zijn (Kleijn et al., 2008; Schekkerman et al., 2005; Teunissen et al., 2008).

Bij dergelijke kruiden-, structuurrijke graslanden met een lage gewasdichtheid speelt de hoge bodemvochtigheid (naast de mestgift) wederom een belangrijke rol. Een hoge bodemvochtigheid remt de groeisnelheid van grassen, waardoor kruiden, die minder concurrentiekrachtig zijn, een kans krijgen om te floreren en er een 'open' vegetatie kan ontstaan (Verhulst et al., 2008).

\section{Reproductie}

Voor het nestelen gebruikt de grutto voornamelijk grasland, waarbij het nest wordt gecamoufleerd door grassprietjes over het nest te buigen. Op locaties met een hoge bodemvochtigheid wordt met hogere dichtheden gebroed dan op locaties met een lage bodemvochtigheid (Kleijn et al., 2008). De intensiteit van het graslandgebruik is tevens van belang: extensieve graslanden kennen een relatief groot uitkomstsucces vergeleken met intensief gebruikte graslanden (Kentie et al., 2011). Voldoende rust in de vorm van een uitgestelde maaidatum tot ten minste 15 juni is van groot belang voor een zo'n hoog mogelijk uitkomstpercentage.

In onderzoek van Kentie et al. (2011) is vastgesteld dat kernen van intensief gebruikt grasland vrijwel ieder jaar functioneren als 'putgebieden', wat betekent dat de reproductie lager is dan de sterfte (combinatie van laag uitkomstsucces en lage kuikenoverleving). Kernen van extensief beheerde graslanden functioneren in sommige jaren als brongebieden, de reproductie is daar groter dan de sterfte. De balans tussen intensief beheerde graslanden en extensief beheerd grasland bepaalt om deze reden de kans op een duurzame populatie. Positieve resultaten in een relatief klein, extensief gebied kunnen teniet worden gedaan door een groot oppervlak intensief beheerd grasland dat als ecologische val functioneert.

Uit verkennende, landelijke analyses komt naar voren dat de minimale omvang van een gebied circa 450 ha bedraagt. Zo'n gebied bestaat voor minimaal 100 ha uit geschikt broedgebied (d.w.z. kuikenland, land met een gunstige vochttoestand en vegetatiesamenstelling en -structuur, met daaromheen een landschappelijke buffer van $600 \mathrm{~m}$, die landschappelijk open is en zonder verstoringsbronnen (Melman et al., 2012; Teunissen et al., 2012). 


\section{Bottleneckfactoren}

\section{Staat van populatie}

De populatie West-Europese grutto's gaat al sinds lange tijd achteruit (Beintema, 2015; Teunissen et al., 2007; Kleijn et al., 2001). Momenteel is de Nederlandse broedpopulatie afgenomen tot ongeveer een vierde van de populatiegrootte in de jaren 70; van ongeveer 120.000 naar 26.000-41.000 broedpaar (Kentie et al., 2016; Melman \& Sierdsema, 2017). De afname van de grutto wordt primair veroorzaakt door een te laag reproductiesucces (= het aantal kuikens dat succesvol opgroeit per broedpaar per jaar). De overleving van de adulte weidevogels is relatief hoog (Bruinzeel, 2010) en lijkt op dit moment niet tot de belangrijkste oorzaken voor de afname te behoren (Wymenga et al., 2018).

\section{Algemeen}

Hierboven zijn de belangrijkste habitatfactoren behandeld. Verandering in deze factoren in ongunstige zin bewerkstelligen verliezen aan de populatieomvang. In de tijd zien we verschuivingen optreden welk van deze factoren dominant is. In de tijd van de ruilverkavelingen (tussen de jaren 50 en midden jaren 90 van de vorige eeuw) was dat met name de ontwatering en de daarmee samenhangende intensivering van het landbouwkundig gebruik. Daarna, vanaf plm. 1995 tot nu, zijn het met name de verdergaande intensivering, mechanisering, grootschaligheid van landbewerking e.d. en de toenemende verdichting van het landschap en de verstedelijking en verrommeling die de achteruitgang bepalen (o.a. Teunissen et al., 2012). Ook predatie wordt een steeds belangrijkere factor. De predatiedruk hangt onder meer samen met de landschappelijke verdichting, maar ook andere ruimtelijke ontwikkelingen zowel binnen natuurgebieden, landbouwgebied als stedelijk gebied (Teunissen, 2016).

\section{Foerageren - adulten}

Voor de adulte vogels is bij het foerageren de laatste jaren de inpikbaarheid van de bodem (bodemweerstand) de belangrijkste bottleneck. Deze weerstand is vooral het resultaat van de toegenomen drooglegging in combinatie met de intensievere bodemverzorging, waarbij regelmatig herinzaaien en egaliseren/herprofileren terugkerende werkzaamheden zijn. Dit wordt nog versterkt door veranderingen in klimaat en neerslagpatroon waarbij tijdens het broedseizoen (zeer) droge periodes zijn en de grond voor de grutto's te hard wordt om in te kunnen prikken.

\section{Foerageren - kuikens}

De intensivering van de landbouw omvat de volgende aspecten: (1) het verlagen van de grondwaterstand, (2) het verhogen van de mestgift, (3) het (her)inzaaien met snelgroeiende grassoorten als Engels raaigras (Lolium perenne) waardoor de kruidenrijkdom afneemt, (4) het egaliseren van weilanden waardoor sterke homogenisering van de vegetatie optreedt, wat allemaal bedoeld is om (5) vroeger, efficiënter, sneller en frequenter te maaien (Kentie et al., 2017).

Bovenstaande veranderingen leiden tot een type grasland waarbinnen de kuikens onvoldoende voedsel vinden, waardoor directe of indirecte sterfte optreedt als gevolg van voedseltekort (Kleijn et al., 2007; Kruk et al., 1997; Schekkerman \& Beintema, 2008). In 'moderne graslanden waar op reguliere wijze wordt geboerd', zijn kruiden nagenoeg afwezig en is de variatie aan structuur, dichtheid en hoogte van de vegetatie laag. In dergelijke gesloten vegetaties ondervinden de kuikens moeite om zich een weg te banen door de vegetatie, laat staan om voldoende insecten te vangen. Het gebrek aan geschikt kuikenland als gevolg van de intensivering van de landbouw leidt in combinatie met andere factoren tot een laag reproductiesucces.

\section{Reproductie}

De intensivering van de landbouw beïnvloedt - naast de kuikenfase zoals beschreven in bovenstaande alinea - ook de nestfase en het uitkomstsucces. De verhoogde frequentie van maaien leidt tot een toename van het aantal nesten, eieren en kuikens dat wordt 'uitgemaaid' en dus vroegtijdig sneuvelt (Teunissen, 2007). Dit, in combinatie met het gebrek aan geschikt kuikenland (zie paragraaf 'foerageren - kuikens') maakt de intensivering van de landbouw tot de belangrijkste bottleneck voor instandhouding van de grutto. In veel gebieden lijkt voor de grutto sprake te zijn van een onbalans tussen de hoeveelheid extensief en intensief grasland. Kernen van extensief beheerde graslanden zijn in veel gevallen dusdanig klein dat positieve resultaten teniet worden gedaan door de intensief beheerde omgeving, die als ecologische val uitwerkt. Slechts een beperkt aantal gebieden bestaat uit een voldoende grote kern van extensieve graslanden met daaromheen een landschappelijk, open gebied. 


\section{Predatie}

Ten slotte speelt de predatie een belangrijke rol voor het reproductiesucces. De verliezen door predatie bij boerenlandvogels zijn de afgelopen jaren toegenomen (Teunissen et al., 2005;

Schekkerman et al., 2009). Hierbij dient te worden opgemerkt dat de impact van predatie sterk samenhangt met de staat van de habitat als geheel. Er is een groot aantal factoren dat de impact van predatie beïnvloedt. Denk hierbij aan de grootte van de lokale weidevogelpopulatie (i.c. vermogen om te verdedigen), openheid van het landschap en aanwezigheid verstorende elementen (nestgelegenheid predatoren), beschikbaarheid schuilplekken voor kuikens in de vorm van structuurrijke graslanden (Gibbons et al., 2007), beschikbaarheid en kwaliteit voedsel (gebrek aan voedsel leidt tot slechte conditie, slechte conditie gaat gepaard met risicovol gedrag zoals bedelen, langer foerageren en noodgedwongen foerageren op plekken met hoge predatiekans (Cresswell et al., 2010)).

\section{Systematiek classificatie habitatkwaliteit}

\section{1) Openheid landschap (Gebiedsniveau)}

De gemiddelde openheid van het landschap wordt op gebiedsniveau beoordeeld en gemeten. Hierbij wordt gebruikgemaakt van een kaartbeeld ontwikkeld met het 'viewscape model' (zie Bijlage B1.1 voor toelichting op totstandkoming van dit kaartbeeld). Dit kaartbeeld geeft inzicht in de openheid van het landschap op verschillende locaties in het gebied. Bij de beoordeling van de habitatkwaliteit zal gebruik worden gemaakt van de gemiddelde openheid van het gebied, volgens onderstaande klasse-indeling.

\begin{tabular}{ll} 
Klasse & $\begin{array}{l}\text { Klassegrenzen (gemiddelde lengte van zichtijn in meters op } \\
\text { gebiedsniveau) }\end{array}$ \\
\hline Slecht & $<100$ \\
\hline Matig & $100-200$ \\
\hline Goed & $200-450$ \\
\hline Zeer goed & $>450$ \\
\hline
\end{tabular}

\section{2) Verstoring (Gebiedsniveau)}

Bij de beoordeling van de habitatkwaliteit zal gebruik worden gemaakt van de gemiddelde verstoringswaarde, volgens onderstaande klasse-indeling. Zie Bijlage B1.2 voor de totstandkoming van het kaartbeeld m.b.t. de mate van verstoring.

\begin{tabular}{ll} 
Klasse & Klassegrenzen (gemiddelde verstoringsklasse op gebiedsniveau) \\
Slecht & $>3$ \\
\hline Matig & $2-3$ \\
\hline Goed & $1-2$ \\
\hline Zeer goed & $0-1$
\end{tabular}

\section{3) Bodemvochtigheid (Gebiedsniveau)}

De bodemvochtigheid wordt op gebiedsniveau beoordeeld en gemeten. Het kaartbeeld zoals ontwikkeld volgens de methodiek zoals beschreven in Bijlage B1.3 geeft inzicht in de bodemvochtigheid op verschillende locaties in het gebied, rekening houdend met kwel, bodemtype en drooglegging. Op het kaartbeeld worden vier klassen onderscheiden: droog grasland, matig vochtig grasland, redelijk vochtig grasland, nat grasland. Bij de beoordeling van de habitatkwaliteit zal gebruik worden gemaakt van het aandeel van het gebied (in percentages) dat is geclassificeerd als redelijk vochtig grasland of nat grasland, volgens onderstaande klasse-indeling.

\begin{tabular}{ll} 
Klasse & $\begin{array}{l}\text { Klassegrenzen (areaal van gebied behorend tot bodemvochtigheidsklasse } \\
\text { 'redelijk vochtig grasland' of 'nat grasland') }\end{array}$ \\
\hline Slecht & $0-25 \%$ \\
\hline Matig & $25-50 \%$ \\
\hline Zeed & $50-75 \%$ \\
\hline
\end{tabular}




\section{4) Omvang leefgebied (Gebiedsniveau)}

Bij de omvang van het leefgebied gaat het om de combinatie van de grootte van het weidevogelvak en het areaal (aaneengesloten) kuikenland ( = zodanig beheerd dat daar kuikenland mag worden verwacht) (Teunissen et al., 2012; Melman et al., 2012). Beide componenten worden hier afzonderlijk beschouwd. De laagste score op beide factoren is bepalend voor het eindoordeel.

\begin{tabular}{lll}
\multirow{2}{*}{ Klasse } & \multicolumn{2}{c}{ Klassegrenzen } \\
\cline { 2 - 3 } Slecht & Beheerd (kuikenland) (ha) & Grootte weidevogelvak (ha) \\
\hline Matig & $<25$ ha & $<50$ ha \\
\hline Goed & $25-75$ ha & $50-300$ ha \\
\hline Zeer goed & $75-150$ ha & $300-600$ ha \\
\hline
\end{tabular}

\section{5) Kruidenrijkdom (Elementniveau)}

De kruidenrijkdom van een perceel kan worden geclassificeerd aan de hand van de vegetatiefasen zoals gedefinieerd door Schippers e.a. (2015). Hierin worden de volgende klassen onderscheiden:

\section{0 - Raaigrasland}

Gras $=$ sterk glanzend groen

Kruiden $=$ niet tot nauwelijks aanwezig

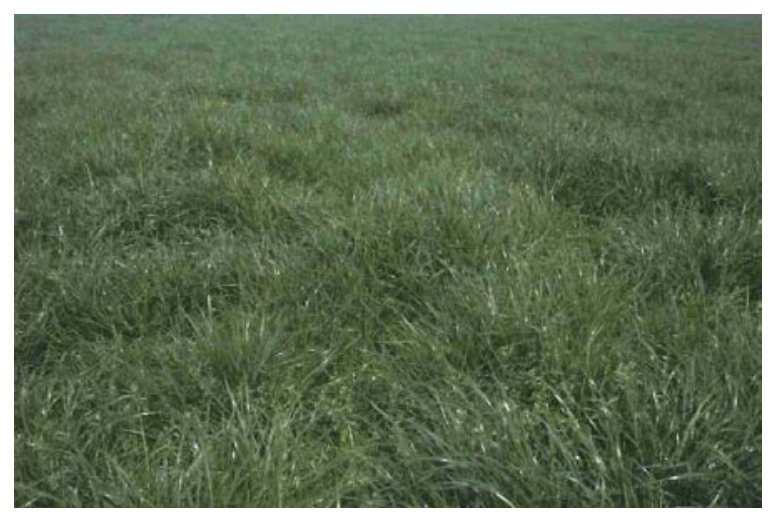

\section{1 - Grassenmix}

Gras = grof mozaïek van grassen. Meerdere groentinten zichtbaar, doordat andere (niet-glanzende grassen) hun intrede doen.

Kruiden = beperkt aantal soorten algemene kruiden, zoals kruipende boterbloem, aardenbloem, pinksterbloem en veldzuring komen in haarden voor.
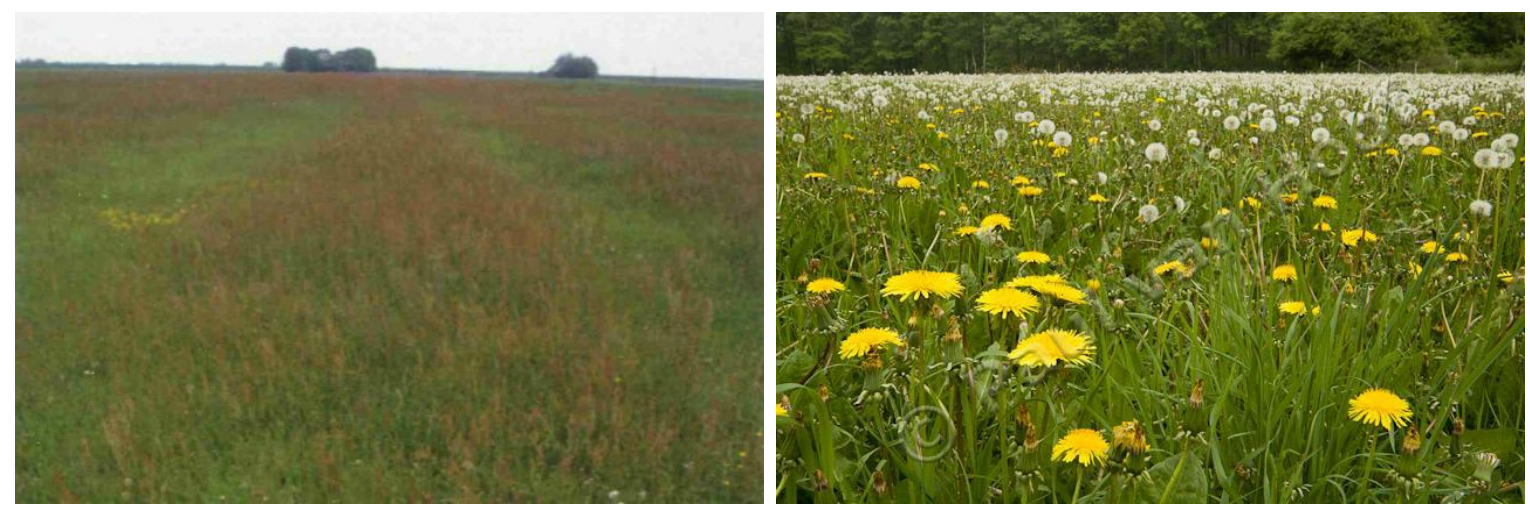


\section{$\underline{2}$ - Dominant stadium}

Gras $=$ meer dan de helft is bedekt met gras dat geen sterk glanzende bladonderzijde heeft. Kruiden $=$ niet $/$ nauwelijks zichtbaar.

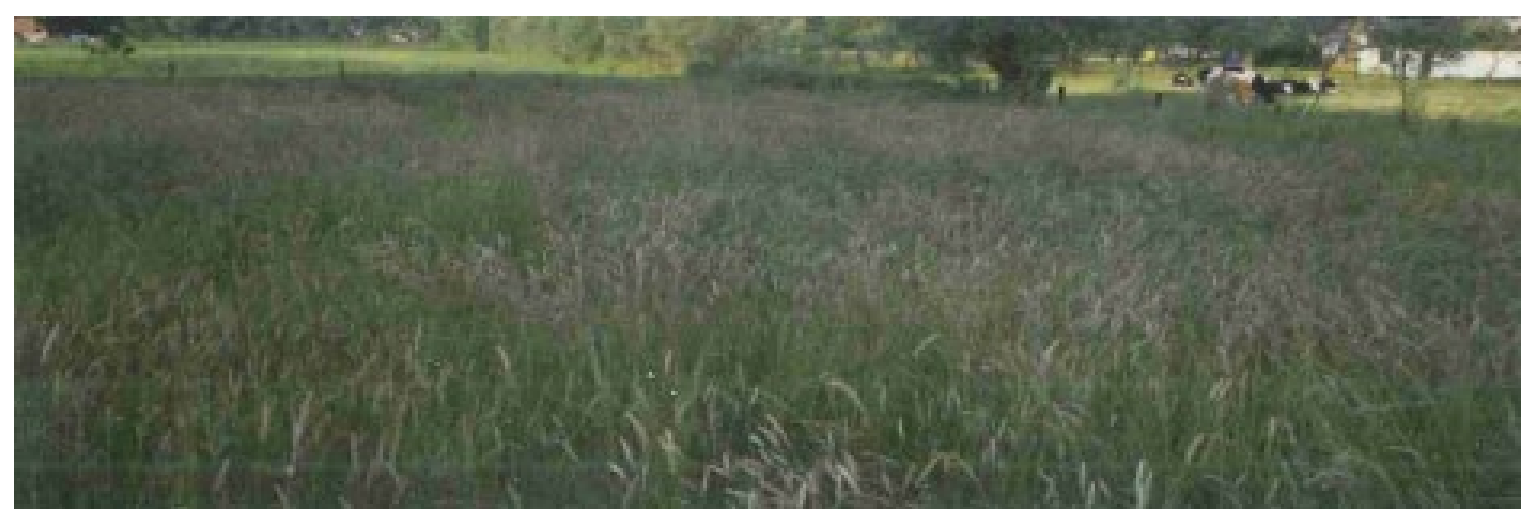

\section{$\underline{3 \text { - Gras-/kruidenmix }}$}

Gras $=$ Grof mozaïek van grassen. Meerdere groentinten zichtbaar, doordat andere (niet-glanzende grassen) talrijk aanwezig zijn.

Kruiden $=$ talrijk aanwezige kruiden komen redelijk gelijkmatig verdeeld over het perceel voor (niet in haarden van één soort).
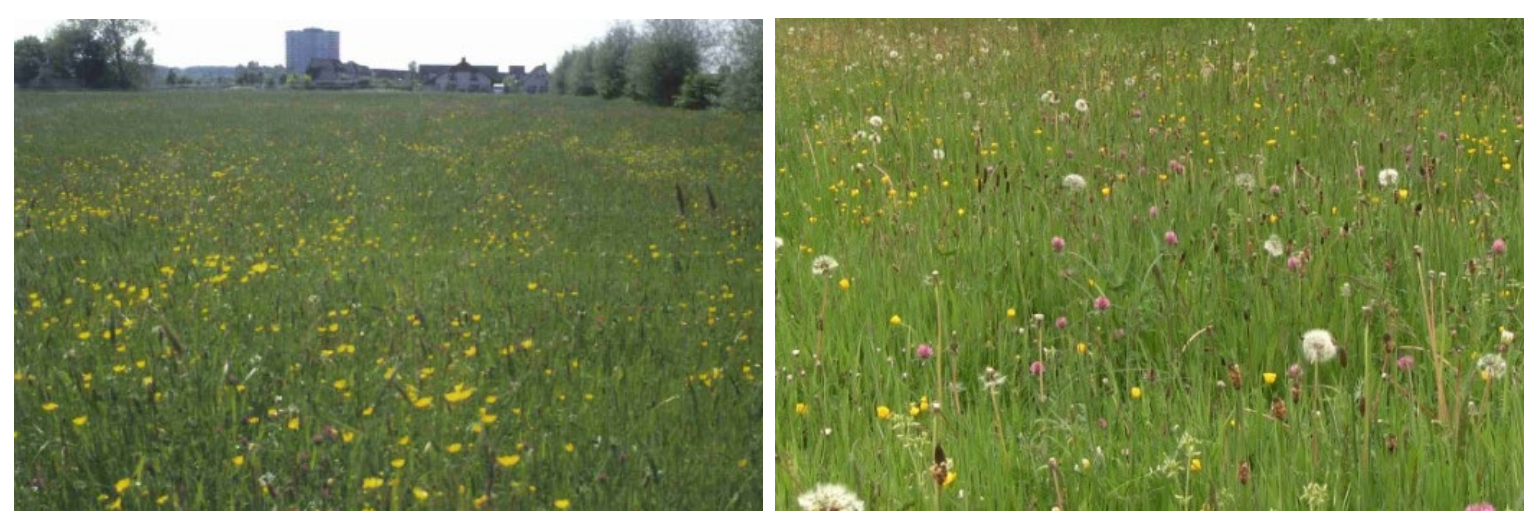

Bij de beoordeling van de habitatkwaliteit zal gebruik worden gemaakt van onderstaande klasseindeling.

\begin{tabular}{ll} 
Klasse & Klassegrenzen (vegetatiefasen Schippers) \\
Slecht & 0 \\
\hline Matig & 2 \\
\hline Goed & 1 \\
\hline Zeer goed & 3 \\
\hline
\end{tabular}

\section{6) Insectenrijkdom (Elementniveau)}

Zeer relevante habitatfactor. Metingen moeilijk te operationaliseren. Voorlopig wordt ervoor gekozen deze niet te meten.

\section{7) Dichtheid vegetatie (Elementniveau)}

Voorlopig wordt de vegetatiefase (zoals vastgesteld bij punt 4) gebruikt als proxy voor de dichtheid van de vegetatie. Als de relatie tussen de vegetatiefase en de dichtheid van de vegetatie niet sterk genoeg blijkt te zijn, kan worden ingezet op een foto-analyse. 


\section{8) Structuurvariatie (Elementniveau)}

Voorlopig wordt de vegetatiefase (zoals vastgesteld bij punt 4) gebruikt als proxy voor de structuurvariatie van de vegetatie. Als deze relatie niet sterk genoeg blijkt te zijn, kan worden ingezet op metingen met een disc-pasture-meter (als men hier de standaarddeviatie van neemt, krijgt men inzicht in de structuurvariatie op perceelniveau). 


\subsection{Ringmus - gidssoort droge dooradering}

\section{Habitateisen}

Algemeen

In ons land komen ringmussen vooral voor in agrarisch gebied en hebben een voorkeur voor halfopen, kleinschalig cultuurland en stadsranden. In zeer open gebieden, uitgestrekte bossen en in binnensteden zijn ze schaars (Bijlsma et al., 2001). Binnen het agrarisch gebied scharrelt de ringmus vaak op en nabij de erven. Erven - besloten open ruimte, voorzien van wat oudere bomen en struiken, met her en der kleine rommelhoekjes, liefst met akkers in de nabijheid - bieden alle benodigde habitat-elementen in nabijheid van elkaar (Melman et al., 2014): nestgelegenheid, schuilgelegenheid en voedsel.

Buiten broedtijd blijven de meeste ringmussen in ons land.

\section{Reproductie}

Ringmussen broeden bij voorkeur in holtes (Snow \& Perrins, 1998). Enerzijds gebeurt dit in natuurlijke holtes in de vorm van oude bomen met holtes (Arnold, 1983). Holtes in het bos worden sinds de jaren 80 echter gemeden (SOVON, 2019). Daartoe zijn oude bomen met holtes alleen relevant als reproductiehabitat wanneer zij zich in relatief open terrein bevinden (op het erf, bomenrijen, bosrand etc.).

Daarnaast maakt de ringmus gebruik van nestkasten en spleten en gaten in gebouwen. De ringmus heeft over het algemeen twee legsels per seizoen; in gunstige omstandigheden kan een derde legsel volgen. Ringmussen broeden regelmatig in kleine kolonies. Bij het eerste legsel levert dit een verhoogd broedsucces op. Vervolglegsels zijn succesvoller in isolatie vanwege de lagere voedselconcurrentie (Sasvári \& Hegyi, 1994).

\section{Foerageren}

Ringmussen hebben een gevarieerd dieet dat zowel uit insecten als zaden bestaat (bv. Anderson et al., 2002; Perkins et al., 2007). Het grootste deel van het dieet van volwassen vogels bestaat uit zaden (Field \& Anderson, 2004). Jaarrond aanwezigheid van zaaddragende gewassen is dus essentieel. Ringmussen consumeren een scala aan zaden, waarbij graan, rogge en haver (Alleyn, 1971 ) en olieachtige zaden zoals zonnebloem- en koolzaad de voorkeur lijken te hebben. Naast gewassen zijn braakliggend land, kruidenrijke bermen/randen of kruidenrijke vegetaties belangrijke zaadbronnen. Broedende vogels vliegen zelden ver van het nest om te foerageren tijdens het broedseizoen. Aanwezigheid van voldoende voedsel binnen $300 \mathrm{~m}$ is bepalend voor het voortplantingssucces (Field \& Anderson, 2004; Deckert, 1962).

Kruidenrijke vegetatie met hoge aantallen invertebraten zijn belangrijk als voedselbron voor nestjongen (Field \& Anderson, 2004) en daarmee voor het broedsucces.

\section{Schuilgelegenheid}

Ringmussen foerageren graag vanuit beschutte plekjes als uitvalbasis. Dit in verband met mogelijk gevaar vanwege roofvogels. Om die reden zijn schuilgelegenheden die landschapselementen (hagen, houtwallen, solitaire bomen, en hoogstamboomgaarden) bieden jaarrond van belang (Siriwardena \& Stevens, 2004).

\section{Overwintering}

Nederlandse ringmussen zijn overwegend standvogel (Bijlsma et al., 2001). De aanwezigheid van zaaddragende wintergewassen is daarom essentieel voor de overleving van de ringmus in de winter (Siriwardena \& Stevens, 2004; Field \& Anderson, 2004). Onderzoek door Kleijn et al. (2014) wees uit dat inzaai van onder andere zomertarwe, bladrammenas, zomergerst en triticale een grote bijdrage leverde aan de zaadbeschikbaarheid en dat dit resulteerde in een proportionele toename van overwinterende akkervogels, waaronder de ringmus. Ook braaklegging kan de zaadbeschikbaarheid verhogen en zo ringmuspopulaties positief beïnvloeden. 


\section{Bottleneckfactoren}

\section{Staat van instandhouding, omvang populatie}

Qua verspreidingsgebied was er de afgelopen decennia sprake van uitbreiding (nieuwe polders) en inkrimping (met name west-Nederland en in de laatste atlasperiode in Brabant en Limburg). De populatie als geheel neemt significant af (Sovon, 2019). Na een explosieve toename van veel populaties ringmussen in Nederland omstreeks de jaren 70 van de vorige eeuw, kende de soort een sterke populatieafname sinds de jaren 80 (Both et al., 2002; SOVON, 2019). De huidige staat van instandhouding is zeer ongunstig (https://www.sovon.nl/soorten). De populatie ringmussen in Nederland wordt geschat tussen de 40.000 en 60.000 broedparen (SOVON, 2019). Begin jaren 80 waren dit er 100,000-500,000 broedparen (Bijlsma et al., 2001).

\section{Algemeen}

Op zoek naar de oorzaak van de ongunstige ontwikkeling geeft de Sovon-atlas (2018) aan dat de broedprestaties niet slecht lijken. Het aandeel succesvol uitgebroede nesten (80\%) en uitvliegende jongen (4 per nest) lijken voldoende (Boele et al., 2017). Timmermans \& De Vries (2016) vonden in hun onderzoeksgebied in ZO-Friesland evenwel dat een groot deel van de eieren niet uitkwam. Een knelpunt lijkt in de vervolglegsels te liggen (Sovon, 2018). De jaarlijkse overleving van de adulten (20-40\%) en jongen (5-15\%) is erg laag (Boele et al., 2017).

Intensivering van landbouw (herbicidentoepassing, zaaizaadschoning, verdwijnen van stoppelvelden, efficiënter grondgebruik, grotere percelen, opruimen overhoekjes) en veranderingen in gewassen (omschakeling van graan naar mais) worden gezien als een belangrijke oorzaak voor de afname van de ringmuspopulatie (Summers-Smith, 1995; Bijlsma et al., 2001). Schaalvergroting en intensivering in de landbouw en verdwijning van kleine landschapselementen leidden tot vermindering van voedselbeschikbaarheid in zomer en winter (zaden en insecten), vermindering van broedgelegenheid en tot afname van de dekking. Ook het veranderde beheer van landschapselementen (enerzijds verwaarlozing/verruiging van de ondergroei, anderzijds verdwijning van de ondergroei door intensief bossenmaaien, waardoor alleen laag gras resteert) beïnvloedt de geschiktheid van het leefgebied voor de ringmus (foerageergelegenheid, dekking).

\section{Reproductie}

Aandacht voor broedgelegenheid is belangrijk. Het lijkt op dit moment landelijk gezien weliswaar niet het grootste knelpunt, maar is in toenemende mate een bron van zorg. Het opruimen van oude bomen met holtes, van kleine landschapselementen op en rond erven, het verdwijnen van oude schuren en hooibergen met hun spouwen, spleten en gaten zijn hier debet aan. Nieuwbouw is vaak strak en biedt zeer beperkt broedgelegenheid. Dat probleem geldt niet alleen voor de ringmus, maar ook voor soorten als de huismus, zwaluwsoorten en uilen. Belangrijk is dus dat er aandacht is voor het behoud van nestelgelegenheid. Dit kan zich richten op het behoud van (knot)bomen, oude schuren en gebouwen, het ophangen van nestkasten en aanbrengen van nestelgelegenheid in nieuwbouw.

\section{Foerageren}

Er zijn aanwijzingen dat het grootste knelpunt voor ringmussen zit in de voedselbeschikbaarheid. De bovengenoemde geringe overleving van zowel adulten als jongen wijzen hierop (Boele at al., 2017). Een eerste knelpunt voor het voedselaanbod vormen de ontwikkelingen in het landbouwkundig gebruik van de percelen zelf. Het gaat om de vergroting van de percelen en de vermindering van het aantal gewassen per bedrijf, waardoor het voedselaanbod eenzijdig wordt en na landbouwkundige bewerkingen voor korte of langere tijd geheel weg kan vallen. Ruimtelijke, kleinschalige diversiteit aan gewassen geeft een betere spreiding van de voedselbeschikbaarheid. Gebruik van insecticiden vermindert het insectenaanbod en gebruik van herbiciden en andere vormen van verbeterde onkruid-beheersing verminderen de kruidengroei op de percelen en daarmee het zaadaanbod. Strokenteelt zou een moderne manier kunnen zijn om tot een ruimtelijk kleinschalige vergroting van gewasdiversiteit te komen.

Een tweede knelpunt wordt gevormd door veranderde condities in de landschapselementen (houtwallen, bosjes e.d.). Door inwaai van meststoffen en influx van mest via regen- en grondwater, verruigt de ondergroei. Daardoor neemt de diversiteit aan plantensoorten af en daarmee de gevarieerdheid in zaadaanbod (Ellenberg, 1989; Maréchal, 1990). Bij uitblijven van onderhoud en 
verwaarlozing ontstaan struiken en ruigtes die op den duur ongeschikt zijn als foerageerhabitat. Anderzijds leidt verruiging er ook wel toe dat juist intensief maaibeheer wordt uitgevoerd (met bossenmaaier) om de verruiging terug te zetten. Met meerdere maaibeurten per jaar resteert een grasvegetatie met losstaande bomen die ook ongeschikt is als foerageergebied (want geen voedselaanbod). Voor ringmussen gunstig beheer van landschapselementen richt zich qua foerageermogelijkheden op bevordering van de struiklaag in houtwallen en op het vermijden van bemesting (inwaai of instroming via regenwater) van deze houtwallen.

\section{Schuilgelegenheid}

Het belang van schuilgelegenheid is nauw verweven met het foerageren. Vanuit veilige plekjes moet het voedsel kunnen worden benaderd. Het gaat om hagen, houtwallen, hoogstamboomgaarden, houtsingels en solitaire bomen en struiken die binnen 50-300 m van plekken met voedselaanbod beschikbaar moeten zijn. Een grotere afstand tussen dekkingsplekken en voedsel brengt met zich mee dat het foerageren meer tijd in beslag neemt (Barta \& Mónus, 2011) en dus minder efficiënt wordt. Vermindering van schuilgelegenheid maakt een gebied minder geschikt.

Hoewel - zoals hierboven aangegeven - predatie niet de hoofdoorzaak van de achteruitgang van de ringmuspopulatie is, helpt het zorgen voor schuilgelegenheid om de predatieverliezen te beperken. Daarom is het van belang bestaande elementen op een juiste manier te onderhouden waarbij compacte en structuurrijke vegetatie verkregen wordt en waar nodig nieuwe elementen aan te leggen. Voor ringmussen gunstig beheer van landschapselementen qua dekking richt zich op bevordering van de struiklaag in houtwallen.

\section{Overwintering}

Voorheen zorgden zomergranen voor graanstoppelvelden in najaar en winter, die een hoog voedselaanbod voor overwinterende vogels opleverden. Met het overschakelen naar wintergranen zijn deze stoppelvelden verdwenen en daarmee het bijbehorende voedselaanbod (Buij \& Kleijn, 2016). Bovendien, de kleine hoeveelheid stoppelvelden die nu nog worden aangetroffen, bevatten nauwelijks nog graanresten of onkruiden vanwege de efficiëntere teelt- en oogstmethoden (Bos, 2013; Bijlsma, 2013). Daar komt nog bij dat achtergebleven resten in veel gevallen al snel na de oogst worden omgeploegd, wat de resten voor de ringmus onbereikbaar maakt. In de winter overblijvende stoppelvelden van zomergraan en aanleg van wintervoedselveldjes dragen bij aan vermindering van de wintersterfte.

\section{Systematiek classificatie habitatkwaliteit}

\section{1) Perceelgrootte (Gebiedsniveau)}

De perceelgrootte wordt op gebiedsniveau beoordeeld en gemeten. Hierbij wordt gebruikgemaakt van een kaartbeeld ontwikkeld op basis van de gegevens zoals verzameld in het BRP-bestand (Basis Registratie Percelen) (zie Bijlage B1.5 voor toelichting op totstandkoming van dit kaartbeeld). Dit kaartbeeld geeft inzicht in de perceelgrootte op verschillende locaties in het gebied. Bij de beoordeling van de habitatkwaliteit zal gebruik worden gemaakt van de gemiddelde perceelgrootte van het gebied, volgens onderstaande klasse-indeling.

\begin{tabular}{ll} 
Klasse & Klassegrenzen (gemiddelde perceelgrootte in hectares) \\
Slecht & $>15$ \\
\hline Matig & $7-10$ \\
\hline Goed & $4-7$ \\
\hline Zeer goed & $<4$ \\
\hline
\end{tabular}

\section{2) Zaaddragende gewassen (Gebiedsniveau)}

De aanwezigheid van zaaddragende gewassen kan op gebiedsniveau worden gemeten. Hierbij kan gebruik worden gemaakt van een kaartbeeld waarin zowel de gewastypen als het agrarisch natuurbeheer zijn geïntegreerd (zie Bijlage B1.6 voor omschrijving). Tot zaaddragende gewassen worden in ieder geval tarwe, rogge, haver, bladrammenas, triticale, zonnebloem en koolzaad gerekend (lijst niet uitputtend) en vormen van agrarisch natuurbeheer, zoals kruidenrijke akkerranden en braakliggend bouwland. Bij de beoordeling van de habitatkwaliteit zal gebruik worden gemaakt van het aandeel van het gebied dat uit bovengenoemde gewastypen bestaat, volgens onderstaande klasse-indeling. 


\begin{tabular}{ll} 
Klasse & Klassegrenzen (aandeel van gebied in percentages) \\
Slecht & $<5 \%$ \\
\hline Matig & $5-10 \%$ \\
\hline Goed & $10-25 \%$ \\
\hline Zeer goed & $>25 \%$
\end{tabular}

\section{3) Gebruik herbiciden en insecticiden (Gebiedsniveau)}

Het gebruik van herbiciden en insecticiden wordt op gebiedsniveau gemeten. Het gaat hierbij zowel om het areaal waarop bestrijdingsmiddelen worden toegepast (aanwezigheid onbespoten randen) als om de intensiteit van het gebruik. Operationalisering van deze factor (selecteren van geschikt kaartmateriaal) wordt in een vervolgproject uitgewerkt.

\section{4) Insectenrijke vegetatie (Gebiedsniveau)}

De aanwezigheid van insectenrijke vegetaties kan op gebiedsniveau worden gemeten. Kruidenrijke vegetaties kunnen in tal van verschijningsvormen voorkomen. Denk hierbij aan kruidenrijke akkerranden, braakliggend bouwland, maar ook aan kruidenrijke bermen en slootkanten. Bij de beoordeling van de habitatkwaliteit zal gebruik worden gemaakt van het aandeel van het gebied dat uit kruidenrijke vegetaties bestaat, volgens onderstaande klasse-indeling.

\begin{tabular}{ll} 
Klasse & Klassegrenzen (aandeel van gebied in percentages) \\
Slecht & $<2.5 \%$ \\
\hline Matig & $2.5-5 \%$ \\
\hline Goed & $5-7.5 \%$ \\
\hline Zeer goed & $>7.5 \%$ \\
\hline
\end{tabular}

\section{5) Nestgelegenheid (Elementniveau)}

Per bedrijf wordt een schatting gemaakt van het aantal potentiële nestlocaties. Deze schatting wordt gerelateerd aan (1) het aantal nestkasten; (2) het aantal bomen met een diameter $>20 \mathrm{~cm}$ op $1,50 \mathrm{~m}$ hoogte; (3) het aantal knotwilgen; (4) aanwezigheid/areaal oude schuren en gebouwen.

Naarmate er meer oude, dikke bomen zijn (diameter op 1,50m $>20 \mathrm{~cm}$ ), is de kans op holtes en dus nestgelegenheid groter. De knotwilg ontwikkelt gemakkelijk holtes, vooral bij het traditionele knotbeheer. Nestkasten bieden eveneens broedgelegenheid, maar ook oude schuren en gebouwen met holtes verzorgen broedmogelijkheid. Om tot een totaalbeeld van de nestelgelegenheid te komen, worden de volgende vuistregels aangehouden:

- Nestkast $=1$

- Bomen diameter $>20 \mathrm{~cm}=1 / 5$ ( 5 bomen $=>1$ nestgelegenheid)

- Knotwilgen $=1 / 3$ ( 3 knotwilgen $=>1$ nestgelegenheid $)$

- Oude schuur/gebouw per 5 vierkante meter $=1$

Vervolgens wordt deze weging opgeteld en aan een van de volgende klassen toegekend:

\begin{tabular}{ll} 
Klasse & Klassegrenzen \\
Slecht & 0 \\
\hline Matig & 1 tot 5 \\
\hline Goed & 6 tot 10 \\
\hline Zeer goed & $>10$ \\
\hline
\end{tabular}

6) Landschapselementen: Aanwezigheid en gelaagdheid (Elementniveau)

De aanwezigheid van landschapselementen wordt op elementniveau (erf) gemeten. Tot landschapselementen mogen hagen, houtwallen, solitaire bomen en hoogstamboomgaarden worden gerekend. $\mathrm{Bij}$ landschapselementen gaat het niet alleen om het areaal. Zo is voor alle landschapselementen relevant of zich in de directe nabijheid een kruidlaag bevindt, zodat voedsel en schuilmogelijkheden zich op korte afstand van elkaar bevinden. Voor houtwallen speelt de gelaagdheid een rol (is sprake van een sterk ontwikkelde boom-, struik- en kruidlaag?). De zoektocht is naar een kwaliteitsparameter die deze factoren integreert. 
7) Voedselbeschikbaarheid winterseizoen (Gebiedsniveau)

Gedurende het winterseizoen zijn ringmussen sterk afhankelijk van de achtergebleven zaaddragende planten. Vaak vinden ze deze binnen braakliggend land, stoppelvelden die achter zijn gebleven na de oogst van zomergraan en randen waarin veel kruiden aanwezig zijn. De totale bedekking van deze habitattypen bepaalt de kwaliteit van het droge dooraderingsleefgebied in de volgende klassen.

\begin{tabular}{ll} 
Klasse & Klassegrenzen (aandeel van gebied in genoemde klassen ( $\%$ )) \\
Slecht & $0 \%$ \\
\hline Matig & $1-2 \%$ \\
\hline Goed & $3-5 \%$ \\
\hline Zeer goed & $>5 \%$ \\
\hline
\end{tabular}




\subsection{Veldleeuwerik - gidssoort open akkerland}

\section{Habitateisen}

\section{Algemeen}

Een aantal habitatfactoren is relevant gedurende meerdere levensstadia (reproductie, foerageren, overwintering, schuilen):

- Openheid landschap: de veldleeuwerik prefereert open landschappen. Percelen die worden omringd door opgaande structuren worden vermeden (Piha et al., 2003; Chamberlain and Gregory, 1999).

- Gewasdiversiteit: een grote gewasdiversiteit is bevorderlijk voor de veldleeuwerik (Chamberlain and Vickery 2000; Geiger et al., 2010; Henderson et al., 2012). In gebieden met een lage gewasdiversiteit vinden veranderingen in de habitat (beschutting, mogelijkheden voor foerageren) op grote schaal en grotendeels gelijktijdig plaats. Het toevoegen van gewastypen (met ieder hun eigen ontwikkelingscyclus en bijbehorende timing) vergroot de spreiding van landbouwwerkzaamheden in ruimte en tijd en vergroot daarmee de kans dat een deel van de percelen geschikt leefgebied vormt om te foerageren en/of reproduceren.

- Gebruik herbiciden en insecticiden: intensief gebruik van herbiciden en insecticiden is van negatieve invloed op de beschikbaarheid van (on)kruiden en insecten in het gewas (Wilson et al., 1999).

\section{Reproductie}

De veldleeuwerik heeft een langgerekt broedseizoen van begin april tot eind augustus, waarin meestal drie broedpogingen worden gedaan (Donald, 2004). De veldleeuwerik is een relatief kortlevende soort. Een hoog reproductiesucces is daarom essentieel voor een stabiele populatie (Hegemann, 2012). Het nest wordt gemaakt tussen relatief korte en 'open/ijle' vegetatie met een hoogte tussen de 15 en $60 \mathrm{~cm}$ en een bedekkingsgraad lager dan 60\% (Wilson et al., 1997; Toepfer and Stubbe, 2001).

Verschillende gewastypen voldoen op verschillende momenten in het seizoen aan deze eisen. Om deze reden is het gunstig als de gewasdiversiteit zo groot mogelijk is.

Een overzicht van een aantal gewastypen en de periode waarin zij geschikt zijn, is te zien in onderstaande tabel. Binnen akkergebieden worden de hoogste dichtheden aan veldleeuweriken aangetroffen in gebieden waar het mozaïek uit geschikte gewastypen bestaat (Kragten et al., 2008; Eraud \& Boutin, 2002; Chamberlain et al., 2000b; Chamberlain \& Gregory, 1999; Wilson et al., 1997).

\begin{tabular}{|c|c|c|}
\hline Gewas & Geschikte periode & Opmerking \\
\hline Wintergranen & April - half mei & Chamberlain et al., 1999; Wilson et al., 1997 \\
\hline Braakpercelen & April - juni & $\begin{array}{l}\text { Geschiktheid afhankelijk van beheer (Chamberlain et al., 1999; Wilson et al., } \\
\text { 1997). Hogere dichtheden dan op gewone akkerpercelen (Henderson et al., } \\
\text { 2000; Chamberlain et al., 1999; Poulsen et al., 1998; Wilson et al., 1997) }\end{array}$ \\
\hline Luzerne & April - juni & $\begin{array}{l}\text { Waardevol reproductiegewas. Gewashoogte en dichtheid van vegetatie maken } \\
\text { dit een geschikt reproductiegewas (Eraud \& Boutin, 2002; Kuiper, 2015) }\end{array}$ \\
\hline Extensief grasland & April - juni & $\begin{array}{l}\text { Hoge dichtheden mogelijk, soms hoger dan op braakliggend bouwland } \\
\text { (Teunissen et al., 2010). Intensief beweide graslanden zijn door nestverliezen } \\
\text { als gevolg van vertrapping ongeschikt (Donald et al., 2002b) }\end{array}$ \\
\hline Zomergraan & Half mei - half juni & Bos et al. (2010) \\
\hline Peulvruchten & Half mei - half juni & Bos et al. (2010) \\
\hline \multicolumn{3}{|l|}{ Bloembollen } \\
\hline Akkerrand & $\begin{array}{l}\text { Afhankelijk van } \\
\text { mengsel, } \\
\text { inzaaimoment e.d. }\end{array}$ & $\begin{array}{l}\text { Veldleeuwerik broedt vrijwel alleen in brede akkerranden (>12 meter) (Arisz } \\
\text { et al. (2009). Akkerranden worden vooral gebruikt om te foerageren en in veel } \\
\text { mindere mate om te broeden (Kuiper et al., 2015). }\end{array}$ \\
\hline
\end{tabular}


Naast het belang van een grote gewasdiversiteit in algemene zin is een aantal gewastypen aan te wijzen dat een belangrijke rol vervult als reproductiehabitat:

- Zomergranen: zomergranen vormen een geschikt en veilig reproductiehabitat in de periode waarin veel andere gewassen ongeschikt worden (bijvoorbeeld wintergranen) en andere gewassen nog geen veilig alternatief bieden (Kragten et al., 2008). Een relatief hoog aandeel zomergranen op gebiedsniveau is om deze reden gunstig voor de veldleeuwerik (Eaton \& Bradbury, 2003).

- Luzerne: zowel de hoogte als de dichtheid van de vegetatie is geschikt. Daarnaast worden percelen met luzerne door de relatief lage maaifrequentie lang genoeg met rust gelaten om een (vervolg)legsel succesvol groot te brengen (Ottens et al., 2013; Kuiper et al., 2013).

- Extensief grasland: kan met zeer hoge dichtheden worden bezet. Lage maaifrequentie zorgt voor veilig reproductiehabitat (Teunissen et al., 2010). Beweid extensief grasland minder geschikt door kans op vertrapping (Donald et al., 2002b).

- Braakliggend bouwland: grote aantrekkingskracht (Bos et al., 2010). Geschiktheid afhankelijk van beheer (Chamberlain et al., 1999; Wilson et al., 1997). Hogere dichtheden dan op gewone akkerpercelen (Henderson et al., 2000; Chamberlain et al., 1999; Poulsen et al., 1998; Wilson et al., 1997).

Om bovenstaande redenen is naast een grote gewasdiversiteit de aanwezigheid van zomergranen, luzerne, extensief grasland en braakliggend bouwland gunstig, omdat deze gewastypen met hoge dichtheden worden bezet of een geschikte reproductiehabitat vormen in periodes waarin andere gewassen ongeschikt zijn.

Ten slotte kan worden opgemerkt dat de aanwezigheid van intensief gebruikt grasland en/of tijdelijk grasland ongunstig is. De hoge maaifrequentie (vooral vanaf mei, iedere drie tot vier weken) maakt het voltooien van de broedcyclus (van nestbouw tot voeren van jongen op nest duurt \pm 35 dagen) niet mogelijk. Het reproductiesucces van veldleeuwerik in intensief en tijdelijk grasland is dan ook zeer laag (Willems et al., 2008). Zowel tijdelijk grasland als intensief grasland kan een grote aantrekkingskracht hebben en daardoor als ecologische val functioneren (Chamberlain et al., 1999; Wilson et al., 1997). Idealiter is het areaal aan tijdelijk en intensief gebruikt grasland op gebiedsniveau zo klein mogelijk, om zodoende de kans te verkleinen dat een veldleeuwerik terechtkomt in de hierboven beschreven ecologische val.

Foerageren voorjaar - zomer

Het dieet van de veldleeuwerik bestaat uit een grote variatie aan ongewervelden en zaden en ander plantmateriaal. Met betrekking tot de ongewervelden vormen kevers (Coleoptra) een belangrijk onderdeel van het dieet (Kuiper et al., 2013; Donald et al., 2001c). Donald et al. (2001) toonden aan dat het consumeren van keverlarven de conditie van jonge veldleeuweriken verbetert. Ook rupsen (Coleoptra) en vliesvleugeligen (Hymenoptera, waaronder mieren, hommels, bijen) vormen een belangrijk onderdeel van het dieet (Flinks \& Pfeiffer, 1998; Donald et al., 2001c). Een groot deel van de larven van bovengenoemde insecten wordt verhoudingsgewijs vooral gevoerd aan de jonge vogels in het nest, vermoedelijk omdat deze makkelijk verteerbaar zijn (Donald et al., 2001c). Al met al kan worden geconcludeerd dat de veldleeuwerik gebaat is bij een gevarieerd en uitvoerig aanbod aan ongewervelden.

Met betrekking tot het plantmateriaal wordt gedurende het broedseizoen een brede range aan plantmateriaal gegeten. Kuiper et al. (2013) vonden dat een groot aandeel van het plantmateriaal bestond uit zaden en soms ook uit ander plantmateriaal (stengels, bladeren en bloemen) van tarwe (Triticum) en Secale.

De veldleeuwerik is een zichtjager en verzamelt zijn voedsel op kale bodems of in lage vegetatie. De vegetatie dient daarom voldoende 'open' te zijn. Er moet gelegenheid zijn om op de kale bodem, door de ijle vegetatie op ongewervelden te jagen. Tot geschikte foerageerhabitat behoren onder andere: - Kruidenrijke graslandstroken langs de randen van percelen, wegen, rijpaden e.d.: de veldleeuwerik foerageert frequent in ijle, kruidenrijke graslandstroken die kunnen ontstaan langs perceelranden en wegbermen. De abundantie en diversiteit aan prooidieren kunnen hier gelijk zijn aan speciaal ingezaaide akkerranden en kunnen de veldleeuwerik daarmee van belangrijk foerageergebied voorzien (Dochy \& Hens, 2005). 
- Braakliggend bouwland: aantrekkelijk vanwege groot voedselaanbod (Vickery et al., 2002).

- Akkerranden: geschikt foerageergebied. Wordt zeer frequent gebruikt (Kuiper et al., 2015). Akkerranden bevatten een groter en gevarieerder aanbod aan insecten dan de gebruikelijke akkerpercelen, zeker in akkerranden met een structuurrijke vegetatie en grote diversiteit aan kruiden (Barker and Reynolds, 1999; Vickery et al., 2009). De gereduceerde input aan pesticiden en een reductie van de bodembewerking leiden tot een hogere abundantie van belangrijke prooidieren, zoals larven bladwespen, rupsen, krekels, sprinkhanen en wantsen (Kuiper et al., 2015).

- Luzerne: geschikt vanwege hoge abundantie aan insecten en ijle vegetatiestructuur (Kuiper et al., 2015).

- Kruidenrijk grasland (Kuiper \& Ottens, 2015).

Tijdens de broedperiode heeft de veldleeuwerik een relatief kleine actieradius. Volgens Kuiper et al. (2015) bedragen voedselvluchten gemiddeld ongeveer $100 \mathrm{~m}$ met een maximum van $250 \mathrm{~m}$. Foerageergebieden, zoals kruidenrijke akkerranden, op meer dan $100 \mathrm{~m}$ van het nest worden beduidend minder bezocht. Om deze reden is het belangrijk dat geschikt foerageergebied zich bevindt in de nabijheid van de reproductiehabitat $(<250 \mathrm{~m}$, bij voorkeur $<100 \mathrm{~m}$ ).

\section{Foerageren winter}

In akkerland overwinterende veldleeuweriken prefereren bepaalde gewashabitats boven andere (graanstoppels, braakland en bieten- en aardappelstoppels). Verklarend voor deze selectieve voorkeuren zijn voedselaanbod en dekking. Binnen de voorkeurhabitats worden graanstoppels het meest geprefereerd (Donald et al., 2001b; Gillings \& Fuller, 2001; Robinson \& Sutherland, 1999). De meest voor de hand liggende verklaring daarvoor is dat foerageren op graankorrels in energetische zin veel efficiënter is dan foerageren op bladgroen en onkruidzaden.

Maisstoppels en grasland worden niet tot nauwelijks gebruikt.

\section{Bottleneckfactoren}

\section{Staat van populatie}

De eens zo algemene veldleeuwerik is sinds de jaren 50 van de vorige eeuw sterk in aantal afgenomen. Met 35.000-45.000 broedparen resteert slechts 5\% van de broedpopulatie uit de jaren 50 (Kwak et al., 2018). Er is een aantal factoren dat van invloed is op de overleving van individuele veldleeuweriken en de soort als geheel. Deze bottleneckfactoren zijn ondergebracht naar hun belang voor een bepaalde functie binnen het leefgebied.

\section{Reproductie}

Een gebrek aan geschikte broedhabitat is de belangrijkste bottleneck (Kuiper et al., 2015). Dit gebrek is een gevolg van:

- Een afname van de gewasdiversiteit, zowel op bedrijfsniveau als op landschapsschaal (Chamberlain \& Vickery, 2000; Kragten et al., 2008). Tussen begin april en halverwege juli moeten veldleeuweriken meerdere legsels groot kunnen brengen. De vegetatie- of gewashoogte is een kritische factor voor het broedsucces. Zodra een gewas te hoog wordt, zal een broedpaar voor een vervolg-legsel uitwijken naar een ander gewas. Het telen van monoculturen over grote oppervlakten zorgt ervoor dat niet kan worden uitgeweken naar een ander gewas met de juiste hoogte. Vervolglegsels kunnen hierdoor mislukken of worden niet gestart (Kuiper \& Ottens, 2015; Kwak et al., 2018; Van Beusekom, 2006).

- Afname van het areaal zomertarwe. Zomertarwe wordt later gezaaid dan wintertarwe (in het voorjaar in plaats van het najaar). In de periode van half mei tot half juni hebben percelen met wintergraan inmiddels een te gesloten gewas, waardoor zij niet geschikt zijn als broedhabitat. Juist in deze periode bevinden percelen met zomertarwe zich in een gunstig ontwikkelingsstadium. Het gewas is dan nog niet te hoog en voldoende open van structuur.

- Intensivering van graslandgebruik: het areaal extensief grasland is sterk afgenomen. Tijdelijke en intensief gebruikte graslanden vormen geen geschikt alternatief: de hoge maaifrequentie leidt tot een laag reproductiesucces (Kuiper et al., 2015). Door opeenvolgende maaibeurten in intensief beheerd grasland is er niet voldoende tijd om vervolglegsels te starten en succesvol groot te brengen. Veldleeuweriken komen hiermee in een ecologische val terecht, omdat tussen de 
maaibeurten en andere landbouwkundige bewerkingen gemiddeld maar 27 tot 30 dagen zit (Ottens et al., 2013; Kuiper et al., 2013).

Foerageren voorjaar - zomer

De voedselbeschikbaarheid voor de veldleeuwerik is de afgelopen decennia sterk afgenomen, mede door het verdwijnen van geschikte foerageerhabitat (extensieve kruidenrijke grasland(stroken), braakliggend bouwland), maar ook door het gebruik van insecticiden en herbiciden (Wilson et al., 1999). Om succesvol nesten groot te brengen, moeten geschikte broedhabitat en geschikt foerageergebied binnen nabijheid van elkaar aanwezig zijn (Kuiper, 2015). In intensief gebruikt akkerland moeten de voedselvluchten tussen nest en foerageergebied over een grotere afstand plaatsvinden (Bos et al., 2010). Hierdoor kost een voedselvlucht per keer meer energie en duurt deze langer. Dit heeft een negatief effect op de reproductie.

\section{Foerageren winter}

Door efficiëntere oogsttechnieken (minder 'morsen' van zaden), afname van het areaal graanstoppels en afname van onkruidpopulaties in het landelijk gebied is het wintervoedselaanbod voor veldleeuweriken en andere zaadeters in de afgelopen decennia sterk afgenomen (o.a. Wilson et al., 1999). Ook de overstap van zomertarwe naar wintertarwe heeft een negatieve invloed op het voedselaanbod in de winter. De groei van wintertarwe vereist het ploegen en zaaien van het land in het najaar, waardoor het areaal stoppelvelden dat rijk is aan zaden afneemt (Donald et al., 2001a, Siriwardena et al., 2008, Geiger et al., 2013).

\section{Systematiek classificatie habitatkwaliteit}

\section{1) Openheid landschap (Gebiedsniveau)}

De gemiddelde openheid van het landschap wordt op gebiedsniveau beoordeeld en gemeten. Hierbij wordt gebruikgemaakt van een kaartbeeld ontwikkeld met het 'viewscape model' (zie Bijlage B1.1 voor toelichting op totstandkoming van dit kaartbeeld). Dit kaartbeeld geeft inzicht in de openheid van het landschap op verschillende locaties in het gebied. Bij de beoordeling van de habitatkwaliteit zal gebruik worden gemaakt van de gemiddelde openheid van het gebied, volgens onderstaande klasseindeling.

\begin{tabular}{ll} 
Klasse & Klassegrenzen (gemiddelde lengte zichtijn in meters) \\
Slecht & $<50$ \\
\hline Matig & $50-200$ \\
\hline Goed & $200-450$ \\
\hline Zeer goed & $>450$ \\
\hline
\end{tabular}

\section{2) Gewasdiversiteit (Gebiedsniveau)}

De gewasdiversiteit wordt op gebiedsniveau beoordeeld en gemeten. Hierbij wordt gebruikgemaakt van een kaartbeeld ontwikkeld op basis van de gegevens zoals verzameld in het BRP-bestand (Basis Registratie Percelen) (zie Bijlage B1.4 voor toelichting op totstandkoming van dit kaartbeeld). Dit kaartbeeld geeft inzicht in de gewasdiversiteit op verschillende locaties in het gebied. Bij de beoordeling van de habitatkwaliteit zal gebruik worden gemaakt van de gemiddelde gewasdiversiteit van het gebied, volgens onderstaande klasse-indeling.

\begin{tabular}{ll} 
Klasse & Klassegrenzen (gemiddelde gewasdiversiteit binnen radius van 300 m) \\
Slecht & $1-3$ \\
\hline Matig & $4-6$ \\
\hline Goed & $7-10$ \\
\hline Zeer goed & $>10$ \\
\hline
\end{tabular}




\section{3) Gebruik herbiciden en insecticiden (gebiedsniveau)}

Het gebruik van herbiciden en insecticiden wordt op gebiedsniveau gemeten. Het gaat hierbij zowel om het areaal waarop bestrijdingsmiddelen worden toegepast (aanwezigheid onbespoten randen) als om de intensiteit van het gebruik. Operationalisering van deze factor (selecteren van geschikt kaartmateriaal) wordt in een vervolgproject uitgewerkt.

4) Hoogwaardige reproductie- en foerageerhabitat: aandeel zomergraan, luzerne, extensief grasland en braakliggend bouwland (Gebiedsniveau) ${ }^{\underline{1}}$

Het aandeel zomergraan, luzerne, extensief grasland en braakliggend bouwland zal op gebiedsniveau worden gemeten. Hierbij zal gebruik worden gemaakt van een kaartbeeld dat is gebaseerd op een samenvoeging van een drietal bestanden. Het BRP-bestand geeft inzicht in de ligging van luzerne en zomergraan (Basis Registratie Percelen). Bestanden die betrekking hebben op de ligging van het agrarisch natuurbeheer kunnen worden gebruikt om de ligging van braakliggend bouwland en luzerne (in vogelakkers) te achterhalen. Ten slotte kan gebruik worden gemaakt van NDVI-gegevens om intensief gebruikte graslanden van extensief gebruikte graslanden te onderscheiden (zie Bijlage B1.6 voor uitgebreide toelichting).

De genoemde gewastypen verschillen waarschijnlijk onderling in relevantie, maar de optelsom in termen van het percentage van het gebied dat bestaat uit deze gewastypen geeft een aardig beeld van de beschikbaarheid van gewassen met een relatief hoge kans op een succesvol legsel. Bij de beoordeling van de habitatkwaliteit zal gebruik worden gemaakt van onderstaande klasse-indeling.

\begin{tabular}{ll} 
Klasse & $\begin{array}{l}\text { Klassegrenzen (percentage van gebied dat bestaat uit zomergraan, } \\
\text { luzerne, extensief grasland en braakliggend bouwland) }\end{array}$ \\
\hline Slecht & $<5$ \\
\hline Matig & $5-10 \%$ \\
\hline Goed & $10-15 \%$ \\
\hline Zeer goed & $>15 \%$ \\
\hline
\end{tabular}

5) Ecologische val: aandeel tijdelijk grasland en intensief gebruikt grasland (Gebiedsniveau) Tijdelijk grasland en intensief gebruikt grasland vormen een ecologische val: beide vormen hebben een (grote) aantrekkingskracht, maar de hoge maaifrequentie leidt tot een laag reproductiesucces (zie habitateisen). Idealiter bestaat een zo klein mogelijk deel van het gebied uit beide gewastypen. Voor het herkennen van tijdelijk grasland kan gebruik worden gemaakt van het BRP-bestand (Basis Registratie Percelen). Voor het onderscheid tussen extensief gebruikt en intensief gebruikt permanent grasland kan gebruik worden gemaakt van NDVI-gegevens. Bij de beoordeling van de habitatkwaliteit zal gebruik worden gemaakt van onderstaande klasse-indeling.

\begin{tabular}{ll} 
Klasse & $\begin{array}{l}\text { Klassegrenzen (percentage van gebied dat bestaat uit tijdelijk grasland } \\
\text { of intensief gebruikt permanent grasland) }\end{array}$ \\
\hline Slecht & $>50$ \\
\hline Matig & $25-50$ \\
\hline Goed & $10-25$ \\
\hline Zeer goed & $<10$ \\
\hline
\end{tabular}

\footnotetext{
1 Factoren 2 en 3 geven tezamen een beeld van de aanwezigheid van geschikte reproductiehabitat: gewassen met een open vegetatiestructuur en een hoogte tussen de 15 en $60 \mathrm{~cm}$. Een alternatieve benadering zou kunnen bestaan uit het meten van de vegetatiehoogte en dichtheid op elementniveau, bijvoorbeeld voor een tiental percelen op gebiedsniveau. Een nadeel van deze methode is dat de selectie van percelen allesbepalend is voor het eindbeeld. Daarnaast is deze aanpak tijdrovend, aangezien op verschillende momenten in het broedseizoen metingen moeten worden uitgevoerd. In het vervolgproject zal worden verkend welke aanpak de voorkeur dient te krijgen.
} 
6) Ruimtelijke samenhang reproductie- en foerageerhabitat (Elementniveau)

De veldleeuwerik heeft een relatief kleine actieradius. Idealiter bevindt de foerageerhabitat zich in nabijheid van de reproductiehabitat. Na het broedseizoen wordt op kaart voor tien territoria bepaald binnen welke afstand geschikte foerageerhabitat met een minimale omvang van 1 ha aanwezig was. Hiertoe wordt een lijn getrokken tussen de locatie van het territorium en de dichtstbijzijnde akkerrand, braakliggend bouwland, of perceel met luzerne. Bij de beoordeling van de habitatkwaliteit zal gebruik worden gemaakt van onderstaande klasse-indeling.

\begin{tabular}{ll} 
Klasse & $\begin{array}{l}\text { Klassegrenzen (gemiddelde afstand tussen locatie territorium en geschikt } \\
\text { foerageerhabitat) }\end{array}$ \\
\hline Slecht & $>250$ \\
\hline Matig & $150-250$ \\
\hline Goed & $50-150$ \\
\hline Zeer goed & $<50$ \\
\hline
\end{tabular}

\section{7) Insectenrijkdom (Elementniveau)}

De insectenrijkdom kan in het veld gemeten worden met een combinatie van methoden. Voor grondgebonden insecten kunnen bodemvallen worden ingegraven, insecten in de vegetatie kunnen met behulp van sleepnetten of klopschermen worden geïnventariseerd en vliegende insecten door het lopen van trajecten met zichtwaarnemingen of met behulp van vangbakken. Er zijn inmiddels ook geautomatiseerde cameravallen in ontwikkeling. Het aantal aangetroffen families bepaalt de insectenrijkdom. Voor opgroeiende veldleeuweriken is een gevarieerd aanbod aan insecten essentieel om de juiste bouwstoffen binnen te krijgen (Kuiper, 2015). Het aantal insecten is eveneens van belang voor opgroeiende kuikens. Onderzoek naar massaliteit en diversiteit aan insecten binnen Interreg-project PARTRIDGE geeft aanwijzingen voor een sterke relatie tussen massaliteit en diversiteit (Maas \& Van der Arend, 2018). Het inschatten van de insectenrijkdom op deze manier is arbeidsintensief en vergt een gedegen soortenkennis. Er kan ook gekozen worden voor een indirecte inschatting, waarbij het gewastype en de kruidenrijkdom als proxy worden genomen voor de insectenrijkdom.

Een minder arbeidsintensieve vorm is om aansluiting te zoeken bij een nieuw meetnet in ontwikkeling van de Vlinderstichting in samenwerking met BoerenNatuur en LTO Noord, het Boeren Insectenmeetnet Agrarische Gebieden (BIMAG). Er wordt in deze monitoring een beperkter aantal soortgroepen gemonitord, alleen dag- en nachtvlinders, die als proxy kunnen dienen voor de algehele insectenstand (De Vlinderstichting, 2019). Het aantal aangetroffen families uit de tabel met klassegrenzen kan dan worden omgezet in een aantal aangetroffen soorten dag- en nachtvlinders.

\begin{tabular}{ll} 
Klasse & $\begin{array}{l}\text { Klassegrenzen (in aantal aangetroffen families/ soorten dag- en } \\
\text { nachtvlinders) }\end{array}$ \\
\hline Slecht & $<40$ \\
\hline Matig & $40-80$ \\
\hline Goed & $80-120$ \\
\hline Zeer goed & $>120$ \\
\hline
\end{tabular}

\section{8) Aanbod winterhabitat (Gebiedsniveau/Elementniveau)}

Ten aanzien van de winterhabitat is zowel de kwantiteit als de kwaliteit van belang. Tot relevante winterhabitat behoren graanstoppels, braakland, bieten- en aardappelstoppels. Hiervan kan simpelweg het areaal worden opgeteld, maar de kwaliteit is ook van belang. De kwaliteit wordt onder andere bepaald door de timing van bespuiten en de efficiëntie van het oogsten. Deze factor dient nader te worden uitgewerkt, waarbij aandacht wordt besteed aan de integratie van beide aspecten.

\section{9) Omvang leefgebied (Gebiedsniveau)}

Bij de omvang van het leefgebied gaat het om de combinatie van de grootte van het gebied en het aandeel van het gebied dat bestaat uit geschikte habitat. Hiertoe dienen allereerst de grenzen van het gebied te worden bepaald. Voor de veldleeuwerik zal moeten worden teruggevallen op een arbitraire 
keuze voor deze grenzen (omdat veldleeuweriken geen nestvlieders zijn, vormen snelwegen of vergelijkbare structuren niet per se een onneembare barrière), afgestemd op:

- Actoren: bijvoorbeeld een werk- of telgebied van een bepaald collectief;

- Topografische eenheid: gebieden die om uiteenlopende redenen als een eenheid worden beschouwd, vanwege landschappelijke kenmerken, historie, cultuur etc.

Voor het areaal geschikte habitat kan gebruik worden gemaakt van het aandeel van voor veldleeuwerik geschikte vormen van agrarisch natuurbeheer (braakliggend bouwland, wintervoedselveldjes, akkerranden etc.) + het aandeel zomertarwe en luzerne.

Beide componenten worden hier afzonderlijk beschouwd. De laagste score op beide factoren is bepalend voor het eindoordeel.

\begin{tabular}{lll} 
Klasse & \multicolumn{2}{c}{ Klassegrenzen } \\
\cline { 2 - 3 } Slecht & $\begin{array}{c}\text { Aandeel geschikte habitat (\% van } \\
\text { gebied) }\end{array}$ & Grootte gebied (ha) \\
\hline Matig & $<2,5 \%$ & $<50$ ha \\
\hline Goed & $2,5-5 \%$ & $50-250$ ha \\
\hline Zeer goed & $5-10 \%$ & $250-600$ ha \\
\hline
\end{tabular}




\subsection{Patrijs - gidssoort droge dooradering/open akkerland}

\section{Habitateisen}

\section{Algemeen}

Een aantal habitatfactoren is relevant gedurende meerdere levensstadia (reproductie, foerageren, overwintering, schuilen):

- Landschapselementen: de aanwezigheid van landschapselementen is bevorderlijk voor de patrijs. Landschapselementen zoals hagen en struwelen worden gebruikt om in te schuilen en te broeden.

- Gewasdiversiteit: een grote gewasdiversiteit is bevorderlijk voor de patrijs (Ronnenberg et al., 2016), alhoewel de drempelwaarde nog niet bekend is (Meynier, 2004). In gebieden met een lage gewasdiversiteit vinden veranderingen in de habitat (beschutting, mogelijkheden voor foerageren) op grote schaal en grotendeels gelijktijdig plaats (Benton et al., 2003). Het toevoegen van gewastypen (met ieder hun eigen ontwikkelingscyclus en bijbehorende timing) vergroot de spreiding van landbouwwerkzaamheden in ruimte en tijd en vergroot daarmee de kans dat een deel van de percelen geschikt leefgebied vormt. Daarnaast zorgt een vergroting van de gewasdiversiteit voor een groter aanbod aan bladmateriaal en zaden.

\section{Reproductie}

De patrijs broedt op de grond. Broeden gebeurt bij voorkeur in ruige, (overjarige) grasachtige vegetatie, idealiter in de nabijheid van/in de dekking van landschapselementen. Dergelijke ruige vegetaties komen voor in de vorm van akkerranden, bermen, overhoekjes en natuurbraak en in de vegetatie langs en onder landschapselementen, zoals hagen, struwelen en houtwallen. Daarnaast worden nesten gemaakt in de randen van graan- en graslandpercelen (Dochy \& Gens, 2005).

\section{Foerageren voorjaar - zomer}

De kuikens moeten gedurende de eerste twee tot drie weken van hun leven op zicht insecten kunnen pikken van de grond of de vegetatie. De dichtheid aan geprefereerde insecten is van grote invloed op de kuikenoverleving (Potts, 1986; Potts \& Aebischer, 1991; Green, 1984). Tot deze insecten behoren wantsen, kleine dagactieve loopkevers, bladhaantjes, snuitkevers, bladwespenlarven, rupsen, sprinkhaan(larven), mieren(larcen) en bladluizen (Potts, 1986; Potts \& Aebischer, 1991).

Oude kuikens en volwassen vogels eten naast insecten ook bladmateriaal en bloemknoppen van verschillende soorten kruiden en gewassen.

De patrijs is daarmee gebaat bij een grote insecten- en kruidenrijkdom. Aan deze habitateis kan zowel worden voldaan binnen het landbouwareaal als binnen seminatuurlijke elementen, zoals kruidenrijke randen en natuurbraak. Ten aanzien van het areaal dat primair voor landbouw wordt gebruikt, is een aantal factoren van invloed op de geschiktheid als foerageergebied:

- Gebruik van bestrijdingsmiddelen: de mate waarin herbiciden en insecticiden worden gebruikt is van grote invloed op de geschiktheid van gewassen om te foerageren. Sotherton (1991, geciteerd in Wilson et al., 2009) vond dat in $6 \mathrm{~m}$ brede onbespoten graanranden tot vier keer zoveel onkruiden en drie keer zoveel insecten voorkwamen als in bespoten delen. Ook in Nederland zijn effecten van onbespoten graanranden (en overigens ook van onbespoten aardappel- en bietranden) op onkruiden insectenpopulaties onderzocht (Haarlemmermeerpolder; De Snoo, 1995). Daarbij bleek dat de onkruidbedekking in onbespoten graanranden aanzienlijk hoger was dan in bespoten graanranden ( $32 \%$ versus $2 \%$ ). Ook was in onbespoten graanranden het aantal soorten onkruiden hoger (17 versus 6) en de insectendichtheid 3 tot 4 keer zo hoog. Aebischer \& Ewald (2004) toonden aan dat de aanwezigheid van dergelijke onbespoten randen de kuikenoverleving van de patrijs ten goede komt.

- Gewasdiversiteit: een grote gewasdiversiteit is gunstig, omdat dit gepaard gaat met een betere spreiding van de landbouwwerkzaamheden in ruimte en een groter aanbod van verschillende structuren en hoogtes. Dit vergroot de kans dat ten minste een deel van de percelen op een bepaald moment in tijd geschikte foerageerhabitat vormt.

- Perceelgrootte: idealiter bestaat een gebied uit een fijn mozaïek van kleine percelen. Dit leidt tot een groter areaal aan 'overgangszones' tussen verschillende gewassen. Dergelijke overgangszones worden door de patrijs veelvuldig gebruikt als foerageergebied (Potts et al., 2012). In veel gevallen 
wordt het hogere/dichtere gewas gebruikt als uitvalsbasis, terwijl in de randzone van het aangrenzende gewas wordt gefoerageerd. Idealiter is tussen beide gewassen ruimte voor grassen en kruiden.

- Gewastype: een aantal gewassen is geschikter als foerageergebied dan andere gewassen. Idealiter bestaat een gebied uit een zo groot mogelijk aandeel gewastypen met een gunstige open vegetatiestructuur, ten gunste van de doorwaadbaarheid. Denk hierbij aan gewastypen zoals zomergranen, wintergranen met aangepaste zaaidichtheid en uien.

De aanwezigheid van voldoende seminatuurlijke, insecten- en kruidenrijke vegetaties is van groot belang voor de patrijs. Dergelijke vegetaties kunnen voorkomen in de vorm van kruidenrijke akkerranden, natuurbraak en overhoekjes (Sotherton et al., 1998), ongemaaide wegbermen en slootkanten (Dover, 2019).

Tijdens de broedtijd zijn patrijzen territoriaal en elk paartje gebruikt een gebied van 6-10 ha (Buner et al., 2005) of minder dan 2 ha in optimale habitat (Šálek et al., 2004). Het creëren van geschikte habitat in een beperkt deel van een gebied in enkele grotere blokken zal dan ten gunste komen van slechts enkele individuen. Het is daarom aan te raden om habitatverbeteringen te verspreiden over een groter deel van een gebied in meerdere kleinere blokken, zodat meer vogels ervan kunnen profiteren (Sotherton, 1998).

\section{Winterhabitat}

In de winter gebruiken patrijzen onbewerkte graanstoppels, kruidenrijke akkerranden of kruidenrijke graslanden om te foerageren (Moorcroft et al., 2002; Hancock \& Wilson, 2002, geciteerd in Wilson et al., 2009). Voor stoppelvelden geldt dat het voedselaanbod mede wordt bepaald door de efficiëntie van de oogsttechniek (bepaald hoeveel er wordt 'gemorst').

\section{Bottleneckfactoren}

\section{Staat van populatie}

In grote delen van Nederland is de patrijs verdwenen of sterk in aantal achteruitgegaan. In de voorheen geschikte landschappen zijn één of meerdere habitateisen verslechterd. Er zijn verschillende bottlenecks te onderscheiden, die zijn ondergebracht naar hun belang voor een bepaalde functie binnen het leefgebied.

\section{Algemeen}

De kleinschaligheid van het landschap is sterk afgenomen. Vanaf de jaren 50 veranderde de gemiddelde kavelgrootte van 2,4 ha in 1950 tot 5 ha in 1990 (CBS, 2017). Daarmee is veel randoppervlak (geschikt reproductie en/of foerageerhabitat) verloren gegaan. Daarnaast is de gewasdiversiteit sterk afgenomen, met een afname van het areaal geschikt foerageergebied als gevolg. Beide factoren tezamen - afname van de kleinschaligheid \& gewasdiversiteit - zorgen voor een lagere diversiteit aan vegetatiestructuren en stadia in zowel ruimte als tijd. Dit maakt het moeilijker om in de directe nabijheid geschikte habitat te vinden.

\section{Reproductie}

Het areaal geschikte reproductiehabitat (ongemaaide bermen en kruidenrijke randen langs en onder landschapselementen) is sterk afgenomen. Dit is verslechterd sinds de grootschalige ruilverkavelingen. Vanaf de jaren 50 veranderde de gemiddelde kavelgrootte van 2,4 ha in 1950 tot 5 ha in 1990 (CBS, 2017). Daarvoor werden duizenden kilometers sloten, onverharde wegen en andere afscheidingen tussen percelen, zoals heggen, houtwallen en bomenrijen opgeruimd.

Foerageren voorjaar - zomer

Een groot aantal onderzoeken wijst in de richting van een te lage kuikenoverleving als de belangrijkste oorzaak voor de sterke afname van de patrijs (o.a. Kuijper, Oosterveld, \& Wymenga, 2009; Potts \& Aebischer, 1994; Potts, 1986; Aebischer \& Ewald, 2004). Een groot aantal factoren ligt hieraan ten grondslag. Naast de reeds genoemde negatieve effecten als gevolg van de schaalvergroting en afname van de gewasdiversiteit lijken bestrijdingsmiddelen ook een belangrijke rol te spelen. De toename in het gebruik van bestrijdingsmiddelen heeft gezorgd voor een sterke afname van akkeronkruiden en 
insecten en daarmee een afname van het voedselaanbod voor patrijzenkuikens (Potts, 1986; Panek, 1992; Rands, 1985). Een groot aantal onderzoeken heeft deze sterke afname van het aantal akkeronkruiden en insecten bevestigd (Boatman et al., 2004; Benton et al., 2002; Robinson \& Sutherland, 2002; Wilson et al., 1999; Moreby et al., 1994). Aebischer en Potts (1998) stellen dat patrijzenkuikens in gebieden waar veelvuldig insecticiden worden gebruikt een 33\% lagere overlevingskans hebben.

De toepassing van herbiciden en insecticiden lijkt ook een direct schadelijk effect te hebben op patrijzen (Lopez-Anita et al., 2015; Millot et al., 2017).

\section{Foerageren winter}

Een gebrek aan wintervoedsel, met name het gebrek aan voldoende kruiden en/of zaden, is een belangrijke bottleneck ten aanzien van de winteroverleving. Monotonere teelten en de efficiëntere oogsttechnieken zorgen ervoor dat een groter areaal ineens geoogst kan worden en er weinig gewasresten (waaronder zaden) achterblijven. De kwaliteit van de stoppelvelden is hierbij ook zeer bepalend. Het is daarbij van belang dat deze stoppelvelden onbewerkt de winter ingaan, zonder late bespuitingen of laat ploegen.

\section{Predatie}

Verschillende onderzoeken onderstrepen de belangrijke rol van predatie. Enerzijds wordt de toename in predatie toegeschreven aan een afnemende vervolging van predatoren. Anderzijds aan de sterke afname van de habitatkwaliteit voor de patrijs. Waar schuilgelegenheden ontbreken of patrijzen door gebrek aan geschikte habitat grote afstanden moeten afleggen, lopen zij een groot risico om te worden gepredeerd. Predatie is daarmee zeker een factor van betekenis, maar ondergeschikt aan de algehele habitatkwaliteit (Kuijper et al., 2009; Aebischer \& Ewald, 2004).

\section{Systematiek classificatie habitatkwaliteit}

\section{1) Perceelgrootte (Gebiedsniveau)}

De perceelgrootte wordt op gebiedsniveau beoordeeld en gemeten. Hierbij wordt gebruikgemaakt van een kaartbeeld ontwikkeld op basis van de gegevens zoals verzameld in het BRP-bestand (Basis Registratie Percelen) (zie Bijlage B1.5 voor toelichting op totstandkoming van dit kaartbeeld). Dit kaartbeeld geeft inzicht in de perceelgrootte op verschillende locaties in het gebied. Bij de beoordeling van de habitatkwaliteit zal gebruik worden gemaakt van de gemiddelde perceelgrootte van het gebied, volgens onderstaande klasse-indeling.

\begin{tabular}{ll} 
Klasse & Klassegrenzen (gemiddelde perceelgrootte in hectares) \\
Slecht & $>15$ \\
\hline Matig & $7-10$ \\
\hline Goed & $4-7$ \\
\hline Zeer goed & $<4$ \\
\hline
\end{tabular}

\section{2) Gewasdiversiteit (Gebiedsniveau)}

De gewasdiversiteit wordt op gebiedsniveau beoordeeld en gemeten. Hierbij wordt gebruikgemaakt van een kaartbeeld ontwikkeld op basis van de gegevens zoals verzameld in het BRP-bestand (Basis Registratie Percelen) (zie Bijlage B1.4 voor toelichting op totstandkoming van dit kaartbeeld). Dit kaartbeeld geeft inzicht in de gewasdiversiteit op verschillende locaties in het gebied. Bij de beoordeling van de habitatkwaliteit zal gebruik worden gemaakt van de gemiddelde gewasdiversiteit van het gebied, volgens onderstaande klasse-indeling.

\begin{tabular}{ll} 
Klasse & Klassegrenzen (gemiddelde gewasdiversiteit binnen radius van 300 m) \\
Slecht & $1-3$ \\
\hline Matig & $4-6$ \\
\hline Goed & $7-10$ \\
\hline Zeer goed & $>10$ \\
\hline
\end{tabular}




\section{3) Gebruik herbiciden en insecticiden (Gebiedsniveau)}

Het gebruik van herbiciden en insecticiden wordt op gebiedsniveau gemeten. Het gaat hierbij zowel om het areaal waarop bestrijdingsmiddelen worden toegepast (aanwezigheid onbespoten randen) als om de intensiteit van het gebruik. Operationalisering van deze factor (selecteren van geschikt kaartmateriaal) wordt in een vervolgproject uitgewerkt.

\section{4) Aandeel kruidenrijke/ruige stroken}

De aanwezigheid van kruidenrijke/ruige stroken wordt op gebiedsniveau gemeten. Hierbij dient in het veld het totale oppervlak aan kruidenrijke/ruige stroken te worden gemeten in. De extensieve perceelranden die worden meegenomen in deze beoordeling hebben een minimale breedte van $6 \mathrm{~m}$ en worden gemaaid na 6 augustus. De gegevens kunnen worden verkregen via Boer \& Bunder of via SCAN-GIS. In beide gevallen worden de resultaten verkregen op perceelniveau en zal dit dienen te worden omgezet naar een percentage voor het werkgebied.

\begin{tabular}{ll} 
Klasse & Klassegrenzen (percentage van gebied) \\
Slecht & $0-1$ \\
\hline Matig & $1-2$ \\
\hline Goed & $2-2,5$ \\
\hline Zeer goed & $>2,5$ \\
\hline
\end{tabular}

\section{5) Aanwezigheid landschapselementen (Gebiedsniveau)}

De aanwezigheid van landschapselementen wordt op gebiedsniveau gemeten. Hierbij dient in het veld te totale lengte aan struweelhagen, houtwallen en hagen te worden geteld. Na optellen dient de lengte te worden teruggerekend naar lengte in kilometers per $100 \mathrm{ha}$. Bij de beoordeling wordt gebruikgemaakt van onderstaande klasse-indeling.

\begin{tabular}{ll} 
Klasse & Klassegrenzen (lengte in $\mathrm{km}$ per $100 \mathrm{ha}$ ) \\
Slecht & $0-1$ \\
\hline Matig & $1-2$ \\
\hline Goed & $2-2,5$ \\
\hline Zeer goed & $>2,5$ \\
\hline
\end{tabular}

\section{6) Aandeel gewastypen met 'open' vegetatiestructuur}

Het aandeel gewastypen met een gunstige vegetatiestructuur wordt op gebiedsniveau gemeten. Met betrekking tot de gewasdichtheid wordt het gewastype als proxy genomen voor de doorwaadbaarheid voor patrijzen. De doorwaadbaarheid wil zeggen hoe makkelijk een patrijs zich tussen het gewas door kan bewegen. De hieronder genoemde lijst met gewastypen is niet uitputtend.

\begin{tabular}{ll} 
Klasse & Gewastypen \\
Slecht & Chicorei, Bieten, Wortelgewassen, Wintergranen zonder beheer \\
\hline Matig & Aardappelen \\
\hline Goed & Zomergranen, Wintergranen met aangepaste zaaidichtheid, Uien \\
\hline Zeer goed & $\begin{array}{l}\text { Zomergranen met aangepaste zaaidichtheid, Vlinderbloemigen, Agrarisch } \\
\text { natuurbeheer }\end{array}$ \\
\hline
\end{tabular}

\section{7) Insectenrijkdom (Elementniveau)}

De insectenrijkdom kan in het veld gemeten worden met een combinatie van methoden. Voor grondgebonden insecten kunnen bodemvallen worden ingegraven, insecten in de vegetatie kunnen met behulp van sleepnetten of klopschermen worden geïnventariseerd en vliegende insecten door het lopen van trajecten met zichtwaarnemingen of met behulp van vangbakken. Er zijn inmiddels ook geautomatiseerde cameravallen in ontwikkeling. Het aantal aangetroffen families bepaalt de insectenrijkdom. Onderzoek naar massaliteit en diversiteit aan insecten binnen Interreg-project PARTRIDGE 
geeft aanwijzingen voor een sterke relatie tussen massaliteit en diversiteit (Maas \& Van der Arend, 2018). Het inschatten van de insectenrijkdom op deze manier is arbeidsintensief en vergt een gedegen soortenkennis. Er kan ook gekozen worden voor een indirecte inschatting, waarbij het gewastype en de kruidenrijkdom als proxy worden genomen voor de insectenrijkdom.

Een minder arbeidsintensieve vorm is om aansluiting te zoeken bij een nieuw meetnet in ontwikkeling van de Vlinderstichting, in samenwerking met BoerenNatuur en LTO Noord en het Boeren Insectenmeetnet Agrarische Gebieden (BIMAG). Er wordt in deze monitoring een beperkter aantal soortgroepen gemonitord, alleen dag- en nachtvlinders, die als proxy kunnen dienen voor de algehele insectenstand (De Vlinderstichting, 2019). Het aantal aangetroffen families uit de tabel met klassegrenzen kan dan worden omgezet in een aantal aangetroffen soorten dag- en nachtvlinders.

\begin{tabular}{ll} 
Klasse & $\begin{array}{l}\text { Klassegrenzen (in aantal aangetroffen families/ soorten dag- en } \\
\text { nachtvlinders) }\end{array}$ \\
\hline Slecht & $<40$ \\
\hline Matig & $40-80$ \\
\hline Goed & $80-120$ \\
\hline Zeer goed & $>120$ \\
\hline
\end{tabular}

\section{8) Winterhabitat}

Het percentage vlakdekkend winterhabitat kan worden verkregen uit gegevens via de SCAN-GISapplicatie. In deze applicatie voeren de agrarische collectieven zelf diverse gegevens in over de percelen, waarop beheerpakketten zijn afgesloten. Vlakdekkende winterhabitat betreft onbewerkt stoppelland, wintervoedselakkers of bloemenblokken. Winterhabitat dat bewerkingen heeft ondergaan voor de winter tellen niet mee in het percentage vlakdekkende winterhabitat.

\begin{tabular}{ll} 
Klasse & Klassegrenzen (percentage vlakdekkend winterhabitat) \\
Slecht & $0-1$ \\
\hline Matig & $1-2$ \\
\hline Goed & $2-2,5$ \\
\hline Zeer goed & $>2,5$ \\
\hline
\end{tabular}

\section{9) Omvang leefgebied}

Bij de omvang van het leefgebied gaat het om de combinatie van de grootte van het gebied en het aandeel van het gebied dat bestaat uit geschikte habitat. Hiertoe dienen allereerst de grenzen van het gebied te worden bepaald. Idealiter wordt hierbij gebruikgemaakt van onneembare barrières voor gezinnen als aanknopingspunten voor de begrenzing. Denk hierbij aan snelwegen, kanalen en dergelijke.

Voor het areaal geschikte habitat kan gebruik worden gemaakt van het aandeel van voor patrijs geschikte vormen van agrarisch natuurbeheer (braakliggend bouwland, wintervoedselveldjes, akkerranden etc.).

Beide componenten worden hier afzonderlijk beschouwd. De laagste score op beide factoren is bepalend voor het eindoordeel.

\begin{tabular}{lll} 
Klasse & \multicolumn{2}{c}{ Klassegrenzen } \\
\cline { 2 - 3 } & $\begin{array}{l}\text { Aandeel geschikt habitat ( } \% \text { van } \\
\text { gebied) }\end{array}$ & Grootte gebied (ha) \\
Slecht & $<2,5 \%$ & $<50$ ha \\
\hline Matig & $2,5-7,5 \%$ & $50-250$ ha \\
\hline Goed & $7,5-12,5 \%$ & $250-500$ ha \\
\hline Zeer goed & $>12,5 \%$ & $>500$ ha
\end{tabular}




\subsection{Grote modderkruiper - gidssoort natte dooradering}

\section{Habitateisen}

\section{Algemeen}

De grote modderkruiper komt voor van Centraal-Europa tot in Azië. Nederland ligt aan de westgrens van het verspreidingsgebied. De soort prefereert relatief ondiepe wateren met een dikke modderlaag en rijke water- en oevervegetatie. Oorspronkelijk lag het leefgebied in de laag dynamische overstromingsvlakten van rivieren en moerasgebieden. Doordat deze gebieden in de loop der eeuwen ingepolderd zijn, bevindt $67 \%$ van het Nederlandse leefgebied zich tegenwoordig in agrarisch gebied (De Bruin \& Kranenbarg, 2009), waardoor poldersloten dus van groot belang zijn geworden. Op basis van de hoogtekaart van Nederland blijkt dat de grote modderkruiper vooral een bewoner is van laag Nederland en het rivierengebied. Van de locaties waar grote modderkruipers aangetoond zijn tijdens onderzoek, bevindt 75\% zich tussen de -1 en +10 meter NAP (De Bruin \& Kranenbarg, 2009).

\section{Reproductie}

De voortplanting vindt plaats van april tot september in ondiepe $(<\mathbf{3 0} \mathbf{c m})$, vegetatierijke delen van het water. Daartoe behoren sterk begroeide oeverzones met helofyten (riet, lisdodde etc.) en kraggen (dichte matten van vegetatie) alsmede ondergelopen graslanden (mits in verbinding met de sloot). Deze zones warmen snel op, wat bevorderlijk is voor de ontwikkeling van de larven. Daarnaast bieden deze zones voldoende schuilmogelijkheden en voorzien zij de larven van voedsel. Eieren die op modderige slootbodems terechtkomen, komen niet uit.

\section{Foerageren}

De grote modderkuiper voedt zich 's nachts met kleine ongewervelden zoals wormen, watervlooien, muggenlarven, waterpissebedden en kreeftjes. Deze sporen ze op in de bodem met behulp van hun bekdraden. De aanwezigheid van een rijke water- en oevervegetatie heeft een gunstig effect op de rijkdom aan macrofauna en dus op het voedselaanbod voor de grote modderkruiper.

Overleving gedurende de winter en zomer

De migratieafstand tussen zomer- en winterhabitat betreft doorgaans enkele honderden meters tot enkele kilometers. In een optimaal leefgebied zijn alle deelhabitats op korte afstand van elkaar aanwezig. De aanwezigheid van diepere waterdelen is essentieel, omdat de soort hier kan overwinteren en overzomeren. De dieren overwinteren op deze locaties door zich in de bodem in te graven, meestal tot $25 \mathrm{~cm}$ diep, soms tot $50 \mathrm{~cm}$ diep (Van Emmerik \& De Nie, 2006).

\section{Schuilmogelijkheden}

De soort houdt zich overdag verscholen in kraggen of dichte water- en oevervegetatie.

\section{Bottleneckfactoren}

\section{Staat van populatie}

De staat van instandhouding (2013) van de grote modderkruiper is zeer ongunstig op alle aspecten (verspreiding, omvang populatie, leefgebied en toekomstverwachting (ANLb, 2016). De grote modderkruiper is opgenomen in Bijlage II van de Habitatrichtlijn en in de Wet natuurbescherming. Op de Nederlandse Rode Lijst heeft de soort de status 'kwetsbaar'.

\section{Algemeen}

De belangrijkste bottleneckfactoren voor de grote modderkruiper zijn intensief schonen/baggeren van sloten. Deze bottleneckfactor heeft verlies dan wel degradatie van de habitat als gevolg en heeft gevolgen voor alle levensfasen van deze soort: reproductie, foerageren, overwintering.

Het eerste belangrijke knelpunt is het te intensief schonen en baggeren van watergangen. Het effect hiervan is tweeledig:

1. Dieren belanden op de kant en sterven. De werkwijze is hierbij van invloed op het effect van deze maatregel. Als er a) snel gewerkt wordt of b) een groot deel van de vegetatie wordt verwijderd of c) de bodem te rigoureus wordt geschoond, zal een groot deel van de populatie op de kant 
terechtkomen. Het aantal vissen dat op de kant terechtkomt, ligt beduidend lager als er langzaam gewerkt wordt (zodat de vissen kunnen vluchten), als de vegetatie boven de bodem wordt afgesneden en als de vegetatie zo veel mogelijk gespaard wordt aan de oever van af waar gewerkt wordt (de meeste vissen verschuilen zich namelijk in de aanliggende oever). Als er op deze manier gewerkt wordt, kan schade op populatieniveau voorkomen worden. Door een polderbeheerplan op te stellen waarin de fasering van de werkzaamheden is beschreven, kunnen populaties over langere termijn worden veiliggesteld.

2. Vernietiging/beschadiging van de habitat: de schadelijke effecten van schonen/baggeren zijn sterk afhankelijk van het aandeel modder en waterplanten dat wordt verwijderd en de omvang van de ingreep (gefaseerd of in zijn geheel). Aanbevolen wordt om altijd gefaseerd te schonen.

\section{Reproductie}

Belangrijkste bottleneckfactor is het ontbreken van geschikte voortplantingslocaties in de vorm van ondiepe ondergelopen oevers en graslanden. Als deze habitat afwezig is in de voortplantings- en opgroeiperiode is het voortplantingssucces gering. Hierdoor is succesvolle voortplanting niet ieder jaar vanzelfsprekend en is sprake van een scheve populatieopbouw met een relatief laag aandeel van juveniele dieren, behalve in jaren waarin voortplanting succesvol plaatsvindt. Dit maakt de populaties vatbaar voor lokaal uitsterven als gevolg van een calamiteit, bijvoorbeeld droogval of dichtvriezen van een watergang. Een van de belangrijkste redenen voor het ontbreken van geschikte voortplantingslocaties is het genoemde tegennatuurlijke waterpeil, dat is ingesteld op optimaal agrarisch gebruik van de aanliggende percelen. Plasdrassituaties voor de soort kunnen gecreëerd worden door het opzetten van het waterpeil en/of het afgraven van de toplaag tot op een niveau dat er in het voorjaar laars-diep water ontstaat.

Overleving gedurende de winter en zomer

Het leefgebied is sterk versnipperd door het huidige waterbeheer. Stuwen, dijken en gemalen zorgen ervoor dat gebieden niet meer overstromen en hydrologisch gescheiden zijn van elkaar. In sommige gebieden is er onvoldoende verbinding met diepere waterdelen waar de soort kan overleven in de winter of tijdens droogval in de zomer (Van Emmerik \& De Nie, 2006).

\section{Systematiek classificatie habitatkwaliteit}

\section{1) Aanwezigheid reproductiehabitat (Elementniveau)}

De aanwezigheid van reproductiehabitat wordt op elementniveau vastgesteld (sloot). De volgende habitatelementen mogen tot reproductiehabitat worden gerekend:

- Sterk begroeide (natuurvriendelijke) oevers. Het gaat hier specifiek om de zone met een diepte van meer dan 5 en minder dan $30 \mathrm{~cm}$ water.

- Kraggen: drijvende eilanden van aquatische vegetatie.

- Ondergelopen graslanden in de vorm van plasdras situaties, mits bereikbaar via de sloot in kwestie.

Van bovenstaande habitatelementen dient het oppervlak in vierkante meters te worden geschat en opgeteld voor de sloot in kwestie. Bij de beoordeling van de habitatkwaliteit zal gebruik worden gemaakt van onderstaande klasse-indeling.

\begin{tabular}{ll} 
Klasse & Klassegrenzen $(\mathrm{m} 2)$ \\
Slecht & $0-250 \mathrm{~m} 2$ \\
\hline Matig & $250-750 \mathrm{~m} 2$ \\
\hline Goed & $750-1500 \mathrm{~m} 2$ \\
\hline Zeer goed & $>1500 \mathrm{~m} 2$ \\
\hline
\end{tabular}

\section{2) Verbinding met diepere waterdelen (Elementniveau)}

De verbinding met diepere waterdelen wordt op elementniveau vastgesteld (sloot). Voor de sloot in kwestie wordt bepaald binnen welke afstand (hierbij telt de afstand die moet worden afgelegd via water, dus niet de onderlinge afstand op een kaartbeeld) deze is verbonden met water dieper dan $1 \mathrm{~m}$. 


\begin{tabular}{ll} 
Klasse & Klassegrenzen $(\mathrm{m})$ \\
Slecht & $>1000 \mathrm{~m}$ \\
\hline Matig & $500-1000 \mathrm{~m}$ \\
\hline Goed & $150-500 \mathrm{~m}$ \\
\hline Zeer goed & $0-150 \mathrm{~m}$ \\
\hline
\end{tabular}

\section{3) Waterdiepte (Elementniveau)}

Meten gebeurt op elementniveau (sloot). Binnen iedere sloot wordt een tiental metingen uitgevoerd met behulp van een peilstok, in het midden van de sloot. Bij de beoordeling van de habitatkwaliteit zal gebruik worden gemaakt van de gemiddelde waterdiepte, volgens onderstaande klasse-indeling.

\begin{tabular}{ll} 
Klasse & Klassegrenzen (in $\mathrm{cm})$ \\
Slecht & $0-25$ \\
\hline Matig & $25-50$ \\
\hline Zeer goed & $50-100$ \\
\hline Goed & $100-150$ \\
\hline Matig & $150-200$ \\
\hline Slecht & $>200$ \\
\hline
\end{tabular}

\section{4) Dikte modderlaag (Elementniveau)}

Meten gebeurt op elementniveau (sloot). Binnen iedere sloot worden een nader te bepalen aantal metingen uitgevoerd. Bij de beoordeling van de habitatkwaliteit zal gebruik worden gemaakt van de gemiddelde dikte van de modderlaag, volgens onderstaande klasse-indeling.

\begin{tabular}{ll} 
Klasse & Klassegrenzen (in cm) \\
Slecht & $0-5$ \\
\hline Matig & $5-10 \mathrm{~cm}$ \\
\hline Goed & $10-20 \mathrm{~cm}$ \\
\hline Zeer goed & $20-40 \mathrm{~cm}$ \\
\hline Goed & $>40 \mathrm{~cm}$ \\
\hline
\end{tabular}

\section{5) Bedekking ondergedoken vegetatie (Elementniveau)}

Meten gebeurt op elementniveau (sloot). Voor de sloot dient te worden ingeschat welk aandeel van de sloot is bedekt met ondergedoken vegetatie. Bij de beoordeling van de habitatkwaliteit zal gebruik worden gemaakt van onderstaande klasse-indeling.

\begin{tabular}{ll} 
Klasse & Klassegrenzen (in \%) \\
Slecht & $0-5$ \\
\hline Matig & $10-25 \%$ \\
\hline Goed & $25-50 \%$ \\
\hline Zeer goed & $50-75 \%$ \\
\hline Goed & $75>\%$ \\
\hline
\end{tabular}

\section{6) Percentage rijke oevervegetatie (helofyten) (Elementniveau)}

Meten gebeurt op elementniveau (sloot). Voor de sloot wordt geschat langs welk aandeel van de sloot een helofytenvegetatie met een minimale breedte van $50 \mathrm{~cm}$ aanwezig is in percentages. Bij de beoordeling van de habitatkwaliteit zal gebruik worden gemaakt van onderstaande klasse-indeling. 


\begin{tabular}{ll} 
Klasse & Klassegrenzen $(\%)$ \\
Slecht & $0-5$ \\
\hline Matig & $10-25 \%$ \\
\hline Goed & $25-50 \%$ \\
\hline Zeer goed & $50-75 \%$ \\
\hline Goed & $75>\%$
\end{tabular}

7) Omvang en samenhang geschikt leefgebied (Gebiedsniveau)

Gebieden met duurzame populaties betreffen gebieden met enkele strekkende kilometers aan

geschikte watergangen. Voor een gebied kan een optelsom worden gemaakt van geschikte sloten.

Maak op kaart een overzicht van de sloten die op ten minste 5 van de bovenstaande 7 criteria goed of zeer goed scoren. Vervolgens mogen de sloten die minder dan $150 \mathrm{~m}$ van elkaar verwijderd zijn en verbonden zijn (dus niet gescheiden door hydrologische bouwwerken) bij elkaar op worden geteld. ${ }^{2} \mathrm{Bij}$ de beoordeling van de habitatkwaliteit zal gebruik worden gemaakt van onderstaande klasse-indeling.

\begin{tabular}{|c|c|}
\hline Klasse & $\begin{array}{l}\text { Klassegrenzen (optelsom van strekkende meters aan geschikte sloten die } \\
\text { met elkaar verbonden zijn) }\end{array}$ \\
\hline Slecht & $<500 \mathrm{~m}$ \\
\hline Goed & $1500-3000 \mathrm{~m}$ \\
\hline Zeer goed & $>3000 \mathrm{~m}$ \\
\hline
\end{tabular}

\footnotetext{
2 Wellicht dat binnen een app dergelijke optelsommen kunnen worden geautomatiseerd.
} 


\subsection{Bittervoorn - gidssoort natte dooradering}

\section{Habitateisen}

Algemeen

De bittervoorn leeft in relatief ondiepe sloten (meestal $45-100 \mathrm{~cm}$ diep), met plantenrijke oevers. Dergelijke oevers bieden beschutting en herbergen een hoog voedselaanbod. De bittervoorn komt wijdverspreid voor in de vaarten en bredere sloten van veel poldergebieden en in de plantenrijke uiterwaardwateren van het rivierengebied.

De bittervoorn toont een beperkte migratie (Van Emmerik \& De Nie, 2006). De soort kan zich in geschikte habitat handhaven binnen kleine oppervlakten. Het is echter gunstig als het leefgebied zich uitstrekt over meerdere kilometers geschikte watergangen, die bovendien met elkaar verbonden zijn en waarbinnen alle benodigde deelhabitats aanwezig zijn. Dit verhoogt de omvang en robuustheid van de populatie en biedt bovendien meer mogelijkheden om gefaseerd beheer uit te kunnen voeren.

\section{Reproductie}

Het is belangrijk dat grote zoetwatermosselen (schildersmossel en zwanenmossel) in het leefgebied voorkomen, omdat deze onmisbaar zijn voor de voortplanting (Smith et al., 2004; De Lange \& Van Emmerik, 2006) en daarmee het voorkomen van de soort (De Bruin, 2007). Vruchtbare vrouwtjes ontwikkelen een legbuis, die onder hun buik hangt. Hiermee worden de eitjes via de uitstroomopening van de mossel in het kieuwweefsel van de mossel gelegd. Het mannetje loost vervolgens zijn zaad bij de instroomopening van de mossel, zodat de eitjes bevrucht worden. Door deze strategie worden de eieren en larven continu voorzien van vers water en zijn uitstekend beschermd tegen rovers. Hierdoor komt een relatief groot aandeel van de eitjes uit. Als de larven ongeveer $1 \mathrm{~cm}$ groot zijn, zwemmen ze uit de mossel.

\section{Foerageren}

De bittervoorn voedt zich door bodemsubstraat op te happen en daaruit eetbare deeltjes te filteren. Het dieet bestaat uit zoöplankton, kleine macrofauna, algen en dood organisch materiaal.

\section{Overwintering}

Doorgaans zwemmen bittervoorns in kleine groepjes, maar in de winter kunnen op beschutte en diepe plaatsen (minimaal $\mathbf{1} \mathbf{~} \mathbf{m}$ ) duizenden dieren samenscholen. Dit gebeurt veelal in dezelfde watergang als waar de reproductiehabitat zich bevindt.

\section{Bottleneckfactoren}

\section{Staat van populatie}

De staat van instandhouding (2013) van de bittervoorn is matig ongunstig. Verspreiding, omvang populatie en toekomstverwachting worden als gunstig beoordeeld. Voor het leefgebied is deze beoordeling matig ongunstig (ANLb, 2016).

Met name de provincie Utrecht bevat veel geschikt leefgebied, de soort is hier aangetroffen in ruim $45 \%$ van de onderzochte kilometerhokken. Ook in Noord-Holland, Zuid-Holland en Gelderland komt bittervoorn veel voor. De langzaam stromende diepere beken en riviertjes van onder andere Overijssel, Noord-Brabant en Limburg behoren ook tot het leefgebied. In Groningen, Drenthe, Flevoland en Zeeland is de soort slechts zeer beperkt aanwezig.

\section{Habitatkwaliteit}

Belangrijkste bottleneckfactor is het verdwijnen van geschikte habitat (ondiepe sloten met sterk begroeide oevers) door:

1. Intensief schonen en baggeren van watergangen.

2. Eutrofiëring door inlaat van gebiedsvreemd, nutriëntenrijk water of door afspoeling van meststoffen. Eutrofiëring kan leiden tot dominantie door algen en het verdwijnen van de voor bittervoorn belangrijke vegetatie en zoetwatermosselen (De Bruin, 2007). 
Naast het verdwijnen van geschikte habitat spelen ook de directe effecten van slootschonen/baggeren een rol. Een direct effect van baggeren en het schonen van de sloot is dat dieren op de kant belanden en sterven, een indirect effect is dat het leefgebied vernietigd wordt. De schadelijke effecten van schonen/baggeren zijn sterk afhankelijk van de omvang en intensiteit hiervan. Aanbevolen wordt om altijd gefaseerd te schonen en zo veel mogelijk van het leefgebied intact te laten door vegetatie te sparen. Daarnaast zijn een hoge werksnelheid en het meenemen van de bodem negatief voor de habitat en overlevingskansen van de aanwezige dieren. Ook het schonen van de aanliggende oever zorgt ervoor dat dieren zich niet in veiligheid kunnen brengen. Een groot aandeel van de vissen zal daarmee op de kant terechtkomen als er snel gewerkt wordt. Het aantal vissen dat op de kant terechtkomt, ligt beduidend lager als er langzaam gewerkt wordt (zodat de vissen kunnen vluchten), als de vegetatie boven de bodem wordt afgesneden en als de vegetatie zo veel mogelijk gespaard wordt aan de oever van af waar gewerkt wordt (de meeste vissen verschuilen zich namelijk in de aanliggende oever). Als er op deze manier gewerkt wordt, kan schade op populatieniveau beperkt worden. Doordat de bittervoorn minder dan grote modderkruiper afhankelijk is van een dichte vegetatie van o.a. kraggen die zich pas na enkele jaren ontwikkelen, is de bittervoorn beter bestand tegen jaarlijks onderhoud. Door een polderbeheerplan op te stellen waarin de fasering van de werkzaamheden is beschreven, kunnen populaties over langere termijn worden veiliggesteld. Door de winterclustering van met name bittervoorn in diepere en beschutte delen, is het van belang om werkzaamheden niet uit te voeren in de winter om te voorkomen dat grote aantallen dieren op de kant belanden. Bij het ontbreken van geschikte overwinterlocaties, kunnen deze habitats plaatselijk gerealiseerd worden door diepere putten uit te graven op bijvoorbeeld kruisingen van sloten, rondom duikers of in bredere watergangen. De verbindingen dienen bovendien jaarrond intact te blijven, zodat beide soorten hun (beperkte) migratie kunnen uitvoeren.

\section{Systematiek classificatie habitatkwaliteit}

\section{1) Verbinding met diepere waterdelen (Elementniveau)}

De verbinding met diepere waterdelen wordt op elementniveau vastgesteld (sloot). Voor de sloot in kwestie wordt bepaald binnen welke afstand (hierbij telt de afstand die moet worden afgelegd via water, dus niet de onderlinge afstand op een kaartbeeld) deze is verbonden met water dieper dan $1 \mathrm{~m}$.

\begin{tabular}{ll} 
Klasse & Klassegrenzen (Dichtstbijzijnde overwinterplaats in meters) \\
Slecht & $>500 \mathrm{~m}$ \\
\hline Matig & $250-500 \mathrm{~m}$ \\
\hline Goed & $100-250 \mathrm{~m}$ \\
\hline Zeer goed & $0-100 \mathrm{~m}$ \\
\hline
\end{tabular}

\section{2) Waterdiepte (Elementniveau)}

Meten gebeurt op elementniveau (sloot). Binnen iedere sloot wordt een tiental metingen uitgevoerd met behulp van een peilstok, in het midden van de sloot. Bij de beoordeling van de habitatkwaliteit zal gebruik worden gemaakt van de gemiddelde waterdiepte, volgens onderstaande klasse-indeling.

\begin{tabular}{ll} 
Klasse & Klassegrenzen (in cm) \\
Slecht & $0-25$ \\
\hline Matig & $25-50$ \\
\hline Zeer goed & $50-100$ \\
\hline Goed & $100-150$ \\
\hline Matig & $150-200$ \\
\hline Slecht & $>200$ \\
\hline
\end{tabular}




\section{3) Dikte modderlaag (Elementniveau)}

Meten gebeurt op elementniveau (sloot). Bij de beoordeling van de habitatkwaliteit zal gebruik worden gemaakt van de gemiddelde dikte van de modderlaag, volgens onderstaande klasse-indeling.

\begin{tabular}{ll} 
Klasse & Klassegrenzen (in $\mathrm{cm})$ \\
Slecht & $0-5$ \\
\hline Matig & $5-10$ \\
\hline Goed & $10-20$ \\
\hline Zeer goed & $20-40$ \\
\hline Goed & $>40$ \\
\hline
\end{tabular}

\section{4) Aanwezigheid zoetwatermosselen}

De aanwezigheid van zoetwatermosselen kan worden vastgesteld na het slootschonen. Bij de beoordeling van de habitatkwaliteit zal gebruik worden gemaakt van onderstaande klasse-indeling.

\begin{tabular}{ll} 
Klasse & Klassegrenzen \\
Slecht & Afwezig \\
\hline Zeer goed & Aanwezig \\
\hline
\end{tabular}

\section{5) Percentage ondergedoken vegetatie (Elementniveau)}

Meten gebeurt op elementniveau (sloot). Voor de sloot dient te worden ingeschat welk aandeel van de sloot bedekt is met ondergedoken vegetatie. Bij de beoordeling van de habitatkwaliteit zal gebruik worden gemaakt van onderstaande klasse-indeling.

\begin{tabular}{ll} 
Klasse & Klassegrenzen (in \%) \\
\hline Slecht & $0-25 \%$ \\
\hline Matig & $25-50 \%$ \\
\hline Goed & $50-75 \%$ \\
\hline Zeer goed & $75>\%$
\end{tabular}

\section{6) Percentage rijke oevervegetatie (helofyten) (Elementniveau)}

Meten gebeurt op elementniveau (sloot). Voor de sloot wordt geschat langs welk aandeel van de sloot een helofytenvegetatie met een minimale breedte van $50 \mathrm{~cm}$ aanwezig is in percentages. Bij de beoordeling van de habitatkwaliteit zal gebruik worden gemaakt van onderstaande klasse-indeling.

\begin{tabular}{ll} 
Klasse & Klassegrenzen (in \%) \\
Slecht & $0-25 \%$ \\
\hline Matig & $25-50 \%$ \\
\hline Goed & $50-75 \%$ \\
\hline Zeer goed & $75>\%$ \\
\hline
\end{tabular}

\section{7) Omvang en samenhang geschikt leefgebied (Gebiedsniveau)}

Gebieden met duurzame populaties betreffen gebieden met enkele strekkende kilometers aan geschikte watergangen. Voor een gebied kan een optelsom worden gemaakt van geschikte sloten. Maak op kaart een overzicht van de sloten die op ten minste 5 van de bovenstaande 7 criteria goed of zeer goed scoren. Vervolgens mogen de sloten die minder dan $150 \mathrm{~m}$ van elkaar verwijderd zijn en verbonden zijn (dus niet gescheiden door hydrologische bouwwerken) bij elkaar op worden geteld. ${ }^{3} \mathrm{Bij}$ de beoordeling van de habitatkwaliteit zal gebruik worden gemaakt van onderstaande klasse-indeling.

3 Wellicht dat binnen een app dergelijke optelsommen kunnen worden geautomatiseerd. 


\begin{tabular}{ll} 
Klasse & $\begin{array}{l}\text { Klassegrenzen (optelsom van strekkende meters aan geschikte sloten die } \\
\text { met elkaar verbonden zijn }\end{array}$ \\
Slecht & $<500 \mathrm{~m}$ \\
\hline Matig & $500-1500 \mathrm{~m}$ \\
\hline Goed & $1500-3000 \mathrm{~m}$ \\
\hline Zeer goed & $>3000 \mathrm{~m}$ \\
\hline
\end{tabular}




\title{
3.7 Torenvalk - Gidssoort open grasland \& open akkerland
}

\begin{abstract}
Habitateisen
Algemeen

De torenvalk broedt in Nederland vooral in open cultuurlandschappen, vrij frequent in bebouwd gebied en steeds minder in bosranden, waar voorheen wel werd gebroed. De 's winters waargenomen torenvalken zijn Nederlandse broedvogels, aangevuld met wat vogels uit omringende landen en NoordEuropa. De winteraantallen hangen samen met sneeuwval en het beschikbare voedselaanbod in het binnen- en buitenland. Plotseling beschikbare voedselvoorraden worden snel gevonden en benut door torenvalken.
\end{abstract}

\section{Foerageren}

Torenvalken zijn sterk afhankelijk van veldmuizen voor overleving en reproductie in Nederland (Bijlsma, 1993) en elders in Noord-Europa (Korpimaki and Norrdahl, 1991; Viitala et al., 1995; Bijlsma, 2012). Op de Veluwe bestond de helft de voedselbiomassa geconsumeerd door torenvalken tijdens de zomer uit veldmuizen; de rest waren vogels (vooral spreeuw en huismus), rosse woelmuizen en bosmuizen (Bijlsma, 2012). In Drenthe waren veldmuizen nog belangrijker met $75 \%$ van de biomassa. In beide gebieden waren veldmuizen de hoofdprooi in de winter (ruim $80 \%$ in termen van biomassa). Ook van voor de oorlog waren dergelijke belangrijke bijdragen van veldmuizen aan het dieet van torenvalken bekend, er lijkt wat dat betreft weinig veranderd (Bijlsma, 2012).

Aangezien veldmuizen een dusdanig groot onderdeel van het dieet uitmaken, is de dichtheid aan muizen van grote invloed op de habitatgeschiktheid voor de torenvalk. Zo blijkt uit onderzoek dat:

- De dichtheid waarmee torenvalken zich in een landschap vestigen afneemt met de dichtheid aan muizen op landschapsschaal, omdat de benodigde territoriumgrootte voor de torenvalk toeneemt bij lagere dichtheden aan muizen (van $6 \mathrm{~km}^{2}$ bij lage dichtheden aan veldmuizen naar $<1 \mathrm{~km}^{2}$ bij hoge dichtheden aan velmuizen (Village, 1982));

- De jaarlijkse variatie in legsel- en broedselgrootte positief gecorreleerd is met het veldmuizenaanbod in Nederland: hoe hoger het aanbod, hoe meer eieren worden gelegd en hoe meer jongen een paar kan laten uitvliegen (Bijlsma, 2012).

De veldmuis vertoont in veel delen van Europa een drie- of vierjarige cyclus (Tkadlec en Stenseth 2001, Lambin et al., 2006), vermoedelijk in relatie met de weersomstandigheden. Dergelijke cycli bestaan uit een opbouwjaar, één of twee piekjaren en een jaar waarin de populatie instort of is ingestort. Een piek in veldmuizen betekent een bovengemiddeld hoge dichtheid van veldmuizen ten opzichte van andere jaren. Torenvalken 'volgen' - net als andere muizenetende roofvogels - deze pieken, waarbij piekjaren garant staan voor veel uitgevlogen jongen. In piekjaren vormt voedselbeschikbaarheid geen limiterende factor; de habitatgeschiktheid voor de torenvalk wordt in deze jaren slechts marginaal bepaald door de habitatgeschiktheid voor veldmuizen. In daljaren is het wel belangrijk dat een gebied geschikt is voor veldmuizen, om zodoende het voedselaanbod voor de torenvalk op peil te houden.

Aangezien de torenvalk dusdanig afhankelijk is van de dichtheid aan veldmuizen, behoren de habitateisen van de veldmuis indirect tot de habitateisen van de torenvalk. De veldmuis bereikt de hoogste dichtheden in extensief gebruikte, grasachtige vegetaties. Dergelijke vegetaties komen voor in de vorm van akkerranden, natuurbraak, extensief beheerde graslanden, dijktaluds, maar ook langs wegbermen, perceelranden en dergelijke (Delattre et al., 1999). Bouwland bevat over het algemeen lage dichtheden aan veldmuizen, met uitzondering van een aantal gras- en kruidachtige gewassen.

Bovenstaande alinea heeft betrekking op de aanwezigheid van veldmuizen en welke factoren daarvoor belangrijk zijn. Voor de torenvalk speelt echter ook de bereikbaarheid van prooidieren een belangrijke rol. De structuur en heterogeniteit van de vegetatie zijn allesbepalend voor de bereikbaarheid van prooidieren (Shrubb, 1980; Aschwanden et al., 2005; Village 2010). 
In hoge kruidenrijk en redelijk gesloten vegetaties (denk aan bepaalde vormen van natuurbraak) kunnen de dichtheden aan veldmuizen weliswaar hoog zijn (Tattersall et al., 1997; Aschwanden et al., 2005), maar de bereikbaarheid van de prooidieren is hier laag (Shrubb, 1980; Aschwanden et al., 2005). Dergelijke vegetaties vormen alleen na maaien (zeer) geschikt foerageergebied. Voor extreem schrale, extensief beheerde graslanden met zeer open structuur is maaien niet noodzakelijk voor de bereikbaarheid van de prooidieren.

Ondanks de relatief lage dichtheden van veldmuizen op reguliere graslanden foerageert de torenvalk hier wel, maar dan uitsluitend na maaien, wanneer het geringe aantal veldmuizen wordt gecompenseerd door de uitstekende bereikbaarheid (Aschwanden et al., 2005).

Uit bovenstaande kan worden opgemaakt dat geschiktheid van een gebied als foerageergebied voor de torenvalk wordt bepaald door twee aspecten: de dichtheid aan prooidieren en de bereikbaarheid/ beschikbaarheid daarvan. Om die reden is een mozaïek van verschillende typen vegetaties gewenst. Enerzijds is de aanwezigheid van extensief beheerde gras- en kruidachtige vegetaties (natuurbraak, extensief grasland, akkerrand, extensief beheerde bermen, oevers etc.) van belang vanwege de hoge dichtheden aan veldmuizen (Tattersall et al., 1997; Aschwanden et al., 2005). Dergelijke vegetaties kunnen als 'haarden' voor muizen functioneren en daarmee een uitstralend effect op de omgeving uitoefenen. In het geval de veldmuizen uitwijken naar de omgeving (bijvoorbeeld recent gemaaid gewas/grasland), zijn zij alsnog bereikbaar voor de torenvalk en dus beschikbaar als voedselbron (Aschwanden et al., 2005).

Anderzijds is de aanwezigheid van voldoende 'regulier' grasland van belang. Hier zijn de dichtheden aan muizen lager, maar door de relatief hoge maaifrequentie is de bereikbaarheid beter. Deze graslanden kunnen door de torenvalk worden benut om periodes te overbruggen waarin de gebieden met de hoogste dichtheden aan veldmuizen nog niet geschikt zijn, omdat deze nog niet gemaaid zijn. Landschappen met een hoog aandeel grasland worden in de hoogste dichtheden bezet (Butet et al., 2010).

Graanvelden zijn minder belangrijk dan grasland, en staande granen worden in de zomer zelfs volledig genegeerd, waarschijnlijk vanwege de lage bereikbaarheid van muizen (Shrubb, 1980). De combinatie van hoogte, dichtheid en gelijkmatigheid van een goed graangewas verhindert succesvol foerageren en de dichte, stijve en stekelige aard van de gewasplanten maakt het grijpen van prooien fysiek moeilijk, zo niet onmogelijk.

\section{Reproductie}

Net als veel andere valken bouwen torenvalken geen eigen nest. De nestplaatskeuze varieert van nestkasten en boomholten, tot nissen en holtes in gebouwen en rotspartijen (Zuid-Europa) en oude nesten van andere soorten, vooral kraaiachtigen. Nestkasten worden ook op grote schaal gebruikt binnen het gehele verspreidingsgebied, net als boomholtes (Del Hoyo et al., 1994). Torenvalken broeden in Nederland veruit het meest in nestkasten (Bijlsma 1993, 2012), wat duidelijk voordelen heeft: de kans op predatie of het mislukken van de broedpoging door weersomstandigheden is aanzienlijk kleiner (Fargallo et al., 2001).

Bijna alle broedgevallen in Nederland zijn tegenwoordig in nestkasten, maar dat is mogelijk een overschat aandeel omdat nesten in kraaiennesten minder snel zullen worden gevonden (Bijlsma, 1993). Met het vergroten van het aanbod aan nestkasten neemt ook de torenvalkdichtheid toe waar nestgelegenheid beperkend is. Het ophangen van nestkasten in Spaanse akkerlandgebieden bijvoorbeeld verhoogde sterk en in relatief korte tijd de dichtheid van de lokale torenvalkpopulatie, een fenomeen dat ook voor andere soorten holenbroeders is waargenomen (Newton, 1994; Fargallo et al., 2009). Torenvalken hebben de neiging nomadisch te zijn, wat betekent dat ze sneller nieuwe gebieden met nestkasten kunnen bezetten dan andere, meer sedentaire roofvogels, zoals kerkuilen (Paz et al., 2011).

Bij plaatsing van een nestkast zijn de locatie en oriëntatie van de nestkast ook van belang. Allereerst varieert de bezettingsgraad van kasten met de beschutting tegen weersinvloeden, waarbij beschutte kasten vaker bezet zijn (kasten niet met de opening richting het westen/zuidwesten 
ophangen) (Valkama en Korpimaki, 1999). Bezetting neemt verder toe met afstand van bosranden, wegen en bewoonde huizen. Drukbezochte gebieden zijn minder geschikt, omdat door verstoring het nestsucces afneemt (Van der Zande en Verstrael, 1985).

\section{Bottleneckfactoren}

\section{Staat van populatie}

$\mathrm{Na}$ een sterke achteruitgang als gevolg van landbouwgif in de jaren 60 van de vorige eeuw, nam de soort weer toe tot de jaren 90. Sinds ongeveer 1990 nemen torenvalken in Nederland alleen maar verder af in aantal, met kleine tijdelijke oplevingen in veldmuisrijke jaren (Sovon, 2020).

\section{Algemeen}

Torenvalken nemen af in aantal met een toenemende intensivering van de landbouw (Butet et al., 2010, Bijslma, 2012; Constantini et al., 2014). Torenvalken in gebieden die worden gekenmerkt door intensieve landbouwpraktijken, leggen onder andere op een later tijdstip eieren en hebben jongen in een slechtere lichaamsconditie dan torenvalken in gebieden met meer extensievere graslanden (Constantini et al., 2014). Dit heeft te maken met de afname van het aanbod aan veldmuizen als gevolg van de intensivering van de landbouw en bijbehorende veranderingen in het landgebruik: het verdwijnen van extensief beheerde graslanden en het omvormen van grasland naar bouwland. De afname van de veldmuis leidt niet alleen tot een sterk afnemende trend bij torenvalken in Nederland, maar ook elders in Europa (Butet et al., 2010). Die intensivering in de landbouw ging gepaard met een afvlakking van aantallen veldmuizen tijdens piekjaren, en minder frequente pieken in aantallen veldmuizen, een normaal verschijnsel tot de jaren 70 van de vorige eeuw, maar tegenwoordig uitzonderlijk (Bijlsma, 2012). Tellingen van muizen op de Veluwe bijvoorbeeld lieten een cyclisch patroon zien met pieken en dalen in aantallen zien in de jaren 70, die afvlakten in de jaren 80 , waarna wederom een patroon van regelmatige, kleinere pieken te zien was in de jaren 90 . Behoudens enkele uitschieters (1991, 2007, 2014, 2019) lijken de pieken in aantallen veldmuizen tot het verleden te behoren, ten nadele van torenvalken en andere muizeneters in cultuurland (Bijlsma, 2012).

\section{Predatie}

Predatie kan lokaal een belangrijk effect hebben op het reproductiesucces. De verliezen door predatie nemen toe, omdat andere predatoren, zoals haviken, te kampen hebben met voedselgebrek, onder meer door dezelfde verarming van het voedselaanbod in cultuurland (Petty et al., 2003; Rutz \& Bijlsma, 2006).

\section{Systematiek classificatie habitatkwaliteit}

\section{1) Voedselaanbod (proxy): aandeel extensieve vegetaties (proxy) (Gebiedsniveau)} Voor een voldoende groot voedselaanbod is de aanwezigheid van extensief beheerde vegetaties van groot belang. Deze stroken hebben relatief hoge dichtheden aan prooidieren en vormen na maaien uiterst geschikt foerageergebied. Daarnaast hebben dergelijke vegetaties een uitstralend effect op de omgeving. Tot dergelijke muizenrijke vegetaties mogen de volgende typen vegetaties worden gerekend: extensief beheerde graslanden, akkerranden, natuurbraak, extensief beheerde bermen, slootkanten en oevers. Het oppervlak behorend tot deze categorieën dient te worden opgeteld in hectaren, waarna het percentage kan worden uitgerekend op gebiedsniveau. Bij de beoordeling van de habitatkwaliteit wordt gebruikgemaakt van onderstaande klasse-indeling.

\begin{tabular}{ll} 
Klasse & Klassegrenzen (percentage van gebied behorend tot genoemde klassen) \\
Slecht & $<2$ \\
\hline Matig & $2-5$ \\
\hline Goed & $5-8 \%$ \\
\hline Zeer goed & $>8 \%$ \\
\hline
\end{tabular}




\section{2) Voedselaanbod (proxy): aandeel grasland (Gebiedsniveau)}

In algemene zin kan worden gesteld dat graslanden geschikt foerageergebied vormen voor de torenvalk, zeker in vergelijking tot bouwland. In gebieden met een hoger aandeel grasland worden hogere dichtheden bezet. Voor de beoordeling dient te worden uitgerekend welk aandeel van het gebied bestaat uit grasland. Bij de beoordeling van de habitatkwaliteit wordt gebruikgemaakt van onderstaande klasse-indeling.

\begin{tabular}{ll} 
Klasse & Klassegrenzen (percentage van gebied behorend tot genoemde klassen) \\
Slecht & $<50 \%$ \\
\hline Matig & $50-75 \%$ \\
\hline Goed & $75-90 \%$ \\
\hline Zeer goed & $90-100 \%$ \\
\hline
\end{tabular}

\section{3) Voedselaanbod (meetmethode 2)}

De dichtheid aan muizen kan worden vastgesteld op basis van de aanwezigheid van muizenholen (let op: wanneer voor deze meting wordt gekozen, komt de methode zoals genoemd bij ' 1 ' te vervallen). Allereerst dienen percelen/elementen (dijken) te worden gekozen alwaar de metingen zullen worden uitgevoerd. Na deze stap wordt binnen ieder element op 10 random gekozen het aantal muizenholen geteld binnen een proefvlak van 1 bij $1 \mathrm{~m}$. Na invoeren worden de aantallen doorvertaald naar dichtheden per ha. Bij de beoordeling van de habitatkwaliteit wordt gebruikgemaakt van onderstaande klasse-indeling.

\begin{tabular}{ll} 
Klasse & Klassegrenzen (muizenholen/ha) \\
Slecht & $0-250$ \\
\hline Matig & $250-1250$ \\
\hline Goed & $1250-2000$ \\
\hline Zeer goed & $>2000$ \\
\hline
\end{tabular}

\section{4) Nestkast}

De beschikbaarheid van een nestkast is van groot belang voor de torenvalk. Zoals eerder beschreven, zijn er meerdere factoren die de geschiktheid van een nestkast beïnvloeden. Optimale nestkasten voldoende aan de volgende eisen:

- De opening van de kast is niet gericht naar het westen/zuidwesten;

- De nestkast hangt hoger dan $4 \mathrm{~m}$;

- De nestkast bevindt zich niet in nabijheid $(<100 \mathrm{~m})$ van verstorende bronnen zoals drukbezochte fiets- en wandelpaden of frequent bezochte delen van een boerenerf.

Bij de beoordeling van de habitatkwaliteit wordt gebruikgemaakt van onderstaande klasse-indeling.

\begin{tabular}{ll} 
Klasse & Klassegrenzen \\
Slecht & Nestkast niet aanwezig \\
\hline Matig & Nestkast aanwezig \& aan 1 van de 3 criteria is voldaan \\
\hline Goed & Nestkast aanwezig \& aan 2 van de 3 criteria is voldaan \\
\hline Zeer goed & Nestkast aanwezig \& aan 3 van de 3 criteria is voldaan \\
\hline
\end{tabular}




\section{Discussie}

De belangrijkste doelstelling van dit project is meer greep te krijgen op de habitatkenmerken van de ANLb-doelsoorten en hoe deze met het agrarisch natuurbeheer (en in mindere mate met inrichting) kunnen worden beïnvloed. Verbetering van de habitat, zowel wat betreft de kwaliteit, de ruimtelijke omvang en ruimtelijke rangschikking vormt de harde kern (het primaire resultaat) van het agrarisch natuurbeheer, met als beoogd effect het bevorderen van de doelsoorten.

Een goed inzicht in de ontwikkeling van de habitatkwaliteit is een belangrijk element bij evaluatie van het agrarisch natuurbeheer. Immers, habitatverandering zal pas plaatsvinden wanneer de aanpassing van het beheer voldoende lang is toegepast. Vervolgens kunnen doelsoorten pas reageren nadat een verandering in de habitat in voldoende mate (kwaliteit en omvang) is gerealiseerd. Met deze twee stappen is een korte of langere periode gemoeid. Grof geschat kan het met habitatverandering om twee tot zes jaar gaan, en met een verandering van de daarmee gelieerde populatieomvang om drie tot tien jaar. Dit is een orde van grootte, per soort en per gebied kan dit sterk uiteenlopen. Dat er zoveel tijd mee gemoeid is, lijkt tot dusverre onderschat. Er zijn nooit studies gedaan op welke termijn veranderingen mochten worden verwacht en welke omvang deze zouden hebben (dat hangt onder meer ook samen met de ontwikkeling aan de deelname aan de regeling die vrijwillig is en daardoor moeilijk planbaar).

Bij het ontwikkelen van beheerpakketten is beïnvloeding van de habitatkwaliteit altijd leidraad geweest [BIJ12-site (https://www.bij12.nl/onderwerpen/natuur-en-landschap/subsidiestelsel-natuuren-landschap/agrarisch-natuurbeheer-anlb/); kenniskring weidevogels: (https://www.natuurkennis.nl/ publicaties/rapporten-kenniskring-weidevogellandschap/)]. Bij het in beeld krijgen van de geschiktste locaties voor beheer en bij de planvorming door de collectieven spelen de habitatkwaliteit en het voorkomen van doelsoorten een rol, maar daarnaast is deelnamebereidheid ook een factor die meespeelt. De match tussen habitatgeschiktheid en deelnamebereidheid is niet $100 \%$. Dat kan ertoe leiden dat ecologisch minder perspectiefvolle locaties toch in beheer worden genomen, omdat de boeren zeer gemotiveerd zijn. Bij de ecologische evaluaties is tot dusverre vooral aandacht geschonken aan aantalsontwikkeling van soorten (abundantie) en in bescheiden mate aan diversiteit (aantal soorten). Aan de voortgang in de verbetering van de habitatkwaliteit is tot nu toe nooit systematisch aandacht geschonken. Ook bij de evaluatie van de ANLb in 2020 lijkt opmerkelijk genoeg geen aandacht te worden besteed aan habitatkwaliteit.

Binnen de collectieven is wel een groeiende aandacht voor habitatkwaliteit en hoe die door beheer (en inrichting) zijn te verbeteren. Zo is tijdens een landelijke studiedag van BoerenNatuur in november 2019 door de kenniskringen van de vier leefgebiedtypen uitgebreid ingegaan op het belang van het herkennen van de potentieel geschikte plekken voor de relevante doelsoorten en daarop zo goed mogelijk in te spelen met de inrichtings- en beheeractiviteiten. Tegelijkertijd is gebleken hoe weerbarstig dit onderwerp in de praktijk is, omdat er zoveel factoren tegelijkertijd spelen en niet alle factoren gemanipuleerd kunnen worden.

Er zijn vele studies die meer of minder onderbouwen welke factoren belangrijke onderdelen zijn van de habitat van soorten. De spreiding (tussen factorwaarde en abundantie) is echter vaak groot, zodat het lastig is om tot een duidelijke grenswaarde te komen aan welke waarden minimaal moet worden voldaan. Tegelijkertijd zijn er vele factoren die de habitatkwaliteit bepalen en is het zeer complex om al deze factoren te integreren tot één kengetal die de habitatkwaliteit weergeeft. Bovendien lopen de eisen van de verschillende soorten uiteen en is er soms sprake van strijdige eisen. Toch is er in de praktijk een grote behoefte aan grenswaarden per factor en aan een integrale beoordeling van de habitatkwaliteit.

Het per relevante doelsoort benoemen van de habitatkwaliteitsfactoren en het uitwerken naar concrete kwaliteitsmaten en kwaliteitsklassen leidt tot bewuster kijken naar gebieden: kan of wordt er 
voldaan aan alle levensvoorwaarden voor reproductie en foerageren? Met de inrichtings- en beheerplannen kan hierop worden ingesprongen. Tijdens voornoemde studiedag van BoerenNatuur vormden de presentaties over de habitatkwaliteit in de verschillende leefgebiedtypen voor de coördinatoren van de collectieven aanleiding om de eigen situaties naar voren te brengen en te projecteren op het gedachtegoed over habitatkwaliteit en problemen/knelpunten met de anderen te bespreken.

Bij het uitwerken van de voorbeeldsoorten voor dit rapport is onze ervaring dat er per factor de nodige informatie is te vinden over de afzonderlijke factoren, maar dat er nauwelijks informatie is over hoe tot een integrale beoordeling van de habitatkwaliteit kan worden gekomen. Daarbij gaat het om een onderlinge weging van de factoren en om eventuele onderlinge afhankelijkheden. Voor weidevogels bijvoorbeeld, waar relatief veel over bekend is, gaat het dan om het relatieve belang van bodemvochtigheid, landschappelijke openheid, zwaarte van het gewas e.d. en over de vraag of een nietoptimale landschappelijke openheid kan worden gecompenseerd door een zeer gunstige bodemvochtigheid of door het minimaliseren van verstoring of door ontwikkeling van kruidenrijk grasland. Voor collectieven kan dit relevant zijn om - uitgaande van de gebiedssituatie - aan die factoren te gaan werken waar knelpunten in de habitatkwaliteit het doelmatigst kunnen worden opgelost. Het lerend beheer leent zich heel goed voor het oppakken van dit soort vragen. De habitatkwaliteitssystematiek met de kentallen zoals hier ontwikkeld, kan hierbij een handzaam hulpmiddel zijn om alle aspecten goed te structureren. Het niet kunnen beschikken over dergelijke kentallen kan doelgerichtheid bevorderen en voorkomen dat wordt door-geoptimaliseerd ten aanzien van nietbeperkende factoren.

Een ander punt is dat er tot dusver binnen agrarisch natuurbeheer niet systematisch is onderzocht welk beheer het snelst tot habitatverbetering leidt. Wel zijn er sinds jaar en dag noties over het verschil tussen eindbeheer en overgangsbeheer. Voor kruidenrijk grasland bijvoorbeeld is een maaidatum van 15 juni of nog later optimaal. Maar bij de omvorming van een ruwbeemd-raaigrasland naar kruidenrijk is in de overgangsperiode een vroegere maaidatum nodig, om zo snel mogelijk tot een minder voedselrijk milieu te komen. Toepassing hiervan in de praktijk is lastig: hoe maak je hierover goede afspraken en hoe werk je aan vertrouwen dat je naar hetzelfde eindresultaat werkt en dat er - binnen het voorbeeld van te ontwikkelen kruidenrijk grasland - niet wordt bij gemest zodat je 'eeuwig' in de omvormingsfase blijft hangen? Veelal wordt erop vertrouwd dat eindbeheer leidt tot goede habitat. Maar juist hier kan zeer veel tijd mee gemoeid zijn, omdat bij een late maaidatum de verschraling niet doorzet. Het gericht kijken naar de ontwikkeling van de habitatkwaliteit en niet doodstaren op beheer als doel, kan helpen deze impasse te doorbreken. De hier ontwikkelde systematiek kan daarbij behulpzaam zijn. 


\section{$5 \quad$ Conclusie en aanbevelingen}

\section{Conclusies}

- Voor alle leefgebiedtypen/habitatcomponenten is een methodiek opgesteld om tot een beoordeling van de habitatkwaliteit te komen. Nog lang niet alles is voldoende uitgewerkt en ten aanzien van de te hanteren kwaliteitsklassen moeten nog veel keuzes worden gemaakt en zal nog veel onderzoek nodig zijn. Belangrijkste winstpunt is dat deze methodiek kan stimuleren om gericht naar habitat-kwaliteit te kijken. Werken aan habitatkwaliteit is de kern van het agrarisch natuurbeheer.

- De systematiek is ontwikkeld voor de verbetering van de uitvoering van het ANLb. Ze kan helpen om: - Bottleneckfactoren te identificeren waarop met het beheer zou moeten worden gestuurd.

- Vaststellen en monitoren dat de ANLb-maatregelen daadwerkelijk ingrijpen op de bottleneckfactoren.

- Voor de doelsoorten die het moeten hebben van het volveldsbeheer (graslanden en akkers, inclusief de perceelranden) lijkt het relatief gemakkelijk tot kwaliteitsklassen te komen en om een relatie te leggen met het ANLb-beheer. Hier ligt een sterke en snel zichtbare relatie met de bedrijfsvoering. Ook lijkt het hiervoor relatief eenvoudig om tot een integrale beoordeling van de habitatkwaliteit te komen, ook al liggen er hier nog belangrijke kennisvragen.

- Voor de soorten van droge dooradering en natte dooradering is het lastiger om tot een goede beoordeling van de habitatkwaliteit te komen. Dat heeft te maken met:

- Sterker dan bij gras- en akkerland de habitateisen van de doelsoorten uiteenlopen: wat voor de ene soort goed is, is voor de andere soort juist niet goed.

- Het feit dat de relatie tussen beheer en habitatkwaliteit lastiger te leggen is. Veel van het beheer is gericht op het in stand houden van landschapselementen en niet op het creëren van habitat - denk bijvoorbeeld aan het knotten van wilgen en het behouden van nestholtes. De relatie met habitatkwaliteit manifesteert zich veelal pas na verloop van jaren.

- Het feit dat veel van deze soorten voor een deel van hun levenscyclus van de dooradering afhankelijk zijn en voor een deel van de aangrenzende akkers en graslanden: de habitat beperkt zich niet tot de dooradering. Daarmee wordt het lastig de vraag te beantwoorden welke bijdrage het ANLb-pakket voor dooradering aan het voortbestaan van soorten levert. Aandacht schenken aan habitatkwaliteit (dooradering én omgeving) is daarbij wéér belangrijk. Bij droge dooradering gaat het met name om de vraag: welke aspecten van de habitat hebben aandacht nodig (wat hebben welke doelsoorten nodig? Hoe ziet het gebied er op dit moment uit, wat zijn verbeter-punten?) en hoe gaan we daar m.b.v. inrichting en beheer voor zorgen (op een later te evalueren manier)?

\section{Aanbevelingen}

De ontwikkelde systematiek moet in de praktijk worden getoetst: niet alleen door onderzoekers, maar zeker ook door de collectieven. Het nu ontwikkelde materiaal is daarvoor inhoudelijk toereikend. Het gaat om de beantwoording van vragen zoals:

- Of de systematiek door collectieven in de praktijk kan worden toegepast

- technische hanteerbaarheid, gebruikersvriendelijkheid

- Of de resultaten to the point en herkenbaar zijn voor de collectieven en voor de onderzoekers (op te vatten als kalibratie en validatie)

- adequaatheid

- herkenbaarheid en plausibiliteit van de vastgestelde kwaliteiten

- Of de resultaten de collectieven helpen bij hun gebiedsanalyse en bij het meer gericht inzetten van het beheer

- Of de resultaten bruikbare input leveren voor lerend beheer. Helpt het de collectieven aan de hand van deze systematiek de kwaliteiten van hun gebied beter te herkennen en benoemen en vergemakkelijkt het de uitwisseling van ideeën hierover met andere collectieven en/of met experts?

Om dit soort vragen te beantwoorden, zou als eerste stap in een vervolgproject de hier ontwikkelde systematiek in concrete handreikingen moeten worden uitgewerkt om de habitatkwaliteit in eigen gebied vast te stellen. Inmiddels is duidelijk dat in 2020 een dergelijk vervolg zal worden opgepakt. 


\section{Literatuur}

Aebischer, N. J., \& Potts, G. R. (1994). Partridge Perdix perdix. Birds in Europe, their erdix perdix conservation status, Eds. GM Tucker, MF Tucker, M. F Heath)-Birdlife Conservation Series, 3, 220-221.

Aebischer, J., \& Potts, G. (1998). Spatial changes in grey partridge (Perdix perdix) distribution in relation to 25 years of changing agriculture in Sussex, U.K. Gibier Faune Sauvage, 15, 293-308.

Aebischer, N.J. \& Ewald, J.A. (2004) Managing the UK Grey Partridge Perdix recovery: population change, reproduction, habitat and shooting. Ibis, 146, 181- 191.

Anderson, T.R., 1984. A quantitative analysis of overlap in nestling diets of village populations of sparrows (Passer spp.) in Poland. Ekologia polska-polish journal of ecology, 32(4), pp.693-707.

Arnold, G.W., 1983. The influence of ditch and hedgerow structure, length of hedgerows, and area of woodland and garden on bird numbers on farmland. Journal of applied Ecology, pp.731-750.

Aschwanden, J., Birrer, S. and Jenni, L., 2005. Are ecological compensation areas attractive hunting sites for common kestrels (Falco tinnunculus) and long-eared owls (Asio otus)?. Journal of Ornithology, 146(3), pp.279-286.

Bak, R., 2015. Torenvalken Falco tinnunculus broedden succesvol op ons balkon op 7 hoog: een dagboek. De takkeling, 23(3), pp.252-268.

Barta, Z., \& Mónus, F. (2011). Degree of synchronization of tree sparrows in flocks under different predation risk. Behaviour, 148(5-6), 733-744.

Beintema AJ, Thissen JB, Tensen D and Visser GH (1991) Feeding ecology of Charadriform chicks in agricultural grassland. Ardea 79, 31-43. Birkhead et al.

Beintema, A. (2015). De grutto. Atlas contact, Arnhem.

Benton, T. G., Bryant, D. M., Cole, L., \& Crick, H. Q. (2002). Linking agricultural practice to insect and bird populations: a historical study over three decades. Journal of Applied Ecology, 39(4), 673-687.

Benton T.G., Vickery J.A., Wilson J.D. (2003) Farmland biodiversity: is habitat heterogeneity the key? Trends Ecol. Evol. 18, 182-188.

Beusekom van, R. (2006). Is er hoop voor de Veldleeuwerik in het agrarisch gebied. De Levende Natuur, 107(3), 138-140.

Bijlsma, R.G., Blomert, A.M., van Manen, W. and Quist, M., 1993. Ecologische atlas van de Nederlandse roofvogels.

Bijlsma, R.G., 2012. Voedsel van Nederlandse Torenvalken Falco tinnunculus in de afgelopen eeuw. De takkeling, 20(3), pp.255-271.

Boag PT (1987) Effects of nestling diet on growth and adult size of zebra finches (Poephila guttata). The Auk 104, 155-66. Chamberlain \& Gregory 1999

Boatman, N.D., Brickle, N.W., Hart, J.D., Milsom, T.I.M.P., Morris, A.J., Murray, A.W.A., Murray, K.A., \& Robertson, P.A., 2004. Evidence for the indirect effects of pesticides on farmland birds. Ibis 146: 131-143

Boer\&Bunder. (z.d.). Opgeroepen op november 18, 2019, van Boer\&Bunder: https://boerenbunder.nl/

BoerenNatuur. (2018). Agrarisch Natuur en Landschapsbeheer. Overzicht Beheerpakketten Agrarisch Natuur-\& Landschapsbeheer. Beheerjaar 2019. Utrecht: BoerenNatuur.

Bos, J., \& Schröder, J. (2009). Akkervogels en landbouw: ecologie, maatregelen en beleid. Wageningen: Plant Research International B.V.

Bos, J., Sierdsema, H., Schekkerman, H., \& van Scharenburg, C. (2010). Een Veldleeuwerik zingt niet voor niets! Schatting van kosten van maatregelen voor akkervogels in de context van een veranderend Gemeenschappelijk Landbouwbeleid. Wageningen: Wettelijke Onderzoekstaken Natuur \& Milieu.

Brabants Landschap. (2017, september 1). Eerste resultaten PARTRIDGE bekend! Opgeroepen op november 18, 2019, van https://www.brabantslandschap.nl/actueel/nieuws/eerste-resultatenpartridge-bekend/ 
Brewin, J., Buner, F., \& Ewald, J. (2019). Patrijzen bescherming. Een leidraad voor herstel van boerenlandnatuur. (F. van Alebeek, Vert.) Zeist: Vogelbescherming Nederland, Interreg North Sea Region PARTRIDGE.

Bruinzeel, L.W. \& A.G.M. Schotman 2011. Onderbouwing verstoringsafstanden weidevogels Fryslân. A\&W rapport.1624/Alterra 2184 Altenburg \& Wymenga ecologisch onderzoek, Feanwâlden/Alterra Wageningen.

Buner, F., Jenny, M., Zbinden, N. \& Naefdaenzer, B. (2005) Ecologically enhanced areas - a key habitat structure for re-introduced grey partridges Perdix perdix. Biological Conservation, 124, 373-381.

Buker, J.B., 1984. Aantal schommelingen bij de veldmuis Mictorus arvalis (Pallas, 1779) in de periode 1978-1981. Lutra 27: 304-311.

Butet, A., Michel, N., Rantier, Y., Comor, V., Hubert-Moy, L., Nabucet, J. and Delettre, Y., 2010. Responses of common buzzard (Buteo buteo) and Eurasian kestrel (Falco tinnunculus) to land use changes in agricultural landscapes of Western France. Agriculture, ecosystems \& environment, 138(3-4), pp.152-159.

CBS. (2017). Minder landschap, meer bebouwing, 1950-2015. Opgeroepen op november 8, 2019, van https://www.cbs.nl/nl-nl/nieuws/2017/10/minder-landschap-meer-bebouwing-1950-2015

Chamberlain, D.E., A.M. Wilson, S.J. Browne \& J.A. Vickery, 1999. Effects of habitat type and management on the abundance of skylarks in the breeding season. Journal of Applied Ecology 36: 856-870

Chamberlain, D.E. \& R.D. Gregory, 1999. Coarse and fine scale habitat associations of breeding skylarks Alauda arvensis in the UK. Bird Study 46: 34-47

Chamberlain D and Vickery JA (2000) Spatial and temporal distribution of breeding Skylarks Alauda arvensis in relation to crop type in periods of population increase and decrease. Ardea 88, 61-73

Costantini, D., Dell'Omo, G., La Fata, I. and Casagrande, S., 2014. Reproductive performance of Eurasian Kestrel Falco tinnunculus in an agricultural landscape with a mosaic of land uses. Ibis, 156(4), pp.768-776.

Cresswell W., Lind J. \& Quinn J.L. 2010. Predatorhunting success and prey vulnerability: Quantifying the spatial scale over which lethal and non-lethal effects of predation occur. Journal of Animal Ecology, 79(3), pp. 556-562. doi: 10.1111/j.1365-2656.2010.01671.x.

Deckert, G., 1962. Zur Ethologie des Feldsperlings (Passer m. montanus L.). Journal für Ornithologie, 103(4), pp.428-486.

De Bruin, A., \& J. Kranenbarg, 2009. Fossiel uit een dynamisch deltagebied. Verspreiding en achteruitgang van de grote modderkruiper in een historisch perspectief \& aanbevelingen voor het behoud van deze soort. RAVON-rapport.

Delattre, P., De Sousa, B., Fichet-Calvet, E., Quéré, J.P. and Giraudoux, P., 1999. Vole outbreaks in a landscape context: evidence from a six year study of Microtus arvalis. Landscape ecology, 14(4), pp.401-412.

Del Hoyo, J., 1994. Family Cracidae (chachalacas, guans and curassows). Handbook of the birds of the world, 2, pp.310-363.

De Snoo, G. R. (1995). Unsprayed field margins: implications for environment, biodiversity and agricultural practice. Leiden University, Leiden.

De Snoo GR (1999) Unsprayed field margins: effects on environment, biodiversity and agricultural practice. Landscape and Urban Planning 46, 151-60. Donald et al. 2002)

De Vlinderstichting. (2019). BIMAG. Boeren meten zelf vlinders. Opgeroepen op december 9, 2019, van https://www.vlinderstichting.nl/bimag

Dochy, O. (2018). Kleine terreinelementen voor akkervogels: wie het kleine niet eert, beheert het grote verkeerd. Natuur.oriolus, 84(3), 68-75.

Donald, P., Evans, A., Buckingham, D., Muirhead, L., \& Wilson, J. (2001). Factors affecting the territory distribution of Skylarks Alauda arvensis breeding on lowland farmland. Bird Study, 48(3), 271-278.

Donald PF, Muirhead LB, Buckingham DL, Evans AD, Kirby WB and Gruar DJ (2001c) Body condition, growth rates and diet of Skylark Alauda arvensis nestlings on lowland farmland. Ibis 143, 658-69.

Donald PF (2004) Eurasian Skylark. In: Handbook of the Birds of the World. Vol. 9. Cotingas to Pipits and Wagtails. Del Hoyo J, Elliott A and Christie D (ed.), pp. 598-9. Lynx Edicions, Barcelona.

Dover, J. (2019). The Ecology of Hedgerows and Field Margins. Routledge. 
Eaton, M. \& R Bradbury, 2003. Using habitat association models to predict impacts of agricultural landscape changes on farmland bird populations. In: Aebischer, N.J., R. Bradbury, M. Eaton, I.G. 202 WOt-rapport 107 Henderson, G.M. Siriwardena \& J. Vickery (Eds.), Predicting the response of farmland birds to agricultural change. Report DEFRA Project BD1618, BTO, Thetford.

Eraud, C. \& J.-M. Boutin, 2002. Density and productivity of breeding Skylarks Alauda arvensis in relation to crop type on agricultural lands in western France. Bird Study 49: 287-296

Fargallo JA, Martínez-Padilla J, Vinuela J, Blanco G, Torre I, Vergara P, et al. 2009. Kestrel-prey dynamic in a Mediterranean region: the effect of generalist predation and climatic factors. PlosOne 4(2):e4311.

Fargallo, J.A., Blanco, G.U.I.L.L.E.R.M.O., Potti, J.A.I.M.E. and Viñuela, J.A.V.I.E.R., 2001. Nestbox provisioning in a rural population of Eurasian Kestrels: breeding performance, nest predation and parasitism. Bird Study, 48(2), pp.236-244.

Field, R.H. and Anderson, G.Q., 2004. Habitat use by breeding Tree Sparrows Passer montanus. Ibis, 146, pp.60-68.

Flinks $\mathrm{H}$ and Pfeifer $\mathrm{F}$ (1988) Einfluß des Nestlingsalters auf die Nahrungszusammensetzung nestjunger Schwarzkehlchen (Saxicola torquata). Journal of Ornithology 129, 317-24. Geiger et al. 2010.

Geiger, F., Hegeman, A., Gleichman, M., Flinks, H., de Snoo, G., Prinz, S., . . Berendse, F. (2014). Habitat use and diet of Skylarks (Alauda arvensis) wintering in an intensive agricultural landscape of the Netherlands. J Ornithol, 155, 507-518.

Gibbons D.W., Amar A., Anderson G.Q.A., Bolton M., Bradbury R.B., Eaton M.A., Evans A.D., Grant M.C., Gregory R.D., Hilton G.M., Hirons G.J.M., Hughes J., Johnstone, I., Newbery P., Peach W.J., Ratcliffe N., Smith K.W., Summers R.W., Walton P. \& Wilson J.D. 2007. The predation of wild birds in the UK: a review of its conservation impact and management. RSPB Research Report No. 23 RSPB, Sandy

Gillings S, Newson SE, Noble DG and Vickery JA (2005) Winter availability of cereal stubbles attracts declining farmland birds and positively influences breeding population trends. Proceedings of the Royal Society B: Biological Sciences 272, 733-9.

Graveland J (1996) Avian eggshell formation in calcium-rich and calcium-poor habitats: importance of snail shells and anthropogenic calcium sources. Canadian Journal of Zoology 74, 1035-44. Hallmann et al. 2014).

Green, R. E. (1984). The feeding ecology and survival of partridge chicks (Alectoris rufa and Perdix perdix) on arable farmland in East Anglia. Journal of Applied Ecology, 817-830.

Green, R.E., Osborne, P.E. and Sears, E.J., 1994. The distribution of passerine birds in hedgerows during the breeding season in relation to characteristics of the hedgerow and adjacent farmland. Journal of Applied Ecology, pp.677-692.

Hancock, M. H., \& Wilson, J. D. (2002). Winter habitat associations of grey partridge Perdix perdix in Scotland, 1997-9. Aspects of Applied Biology, 67, 171-178.

Hegemann A, Matson KD, Flinks H and Tieleman I (2012) Strive to survive, the skylark's ecology and physiology in an annual-cycle perspective. Chapter 9, Offspring pay sooner, parents pay later: Experimental evidence that immune function mediates trade-offs between parental effort and survival, pp 131-151. PhD Thesis, University of Groningen, the Netherlands.

Henderson IG, Holland JM, Storkey J, Lutman P, Orson J and Simper J (2012) Effects of the proportion and spatial arrangement of un-cropped land on breeding bird abundance in arable rotations. Journal of Applied Ecology 49, 883-91.

Hegyi, Z., \& Sasvari, L. (1998). Parental condition and breeding effort in waders. Journal of Animal Ecology, 41-53.

Johnston RD (1993) Effects of diet quality on the nestling growth of a wild insectivorous passerine, the house martin Delichon urbica. Functional Ecology 7, 255-66.

Kentie, R., Hooijmeijer, J. C. E. W., Both, C., \& Piersma, T. (2011). Grutto's in ruimte en tijd 20072010, eindrapport. Directie Kennis, Ministerie van Landbouw, Natuur en Voedselkwaliteit, Den Haag.

Kentie, R., E. van der Velde, J. Hooijmeijer \& T. Piersma 2017. De Grutto Monitor 2016. Onderzoeksrapport Conservation Ecology Group, Groningen Institute for Evolutionary Life Sciences (GELIFES), Rijksuniversiteit Groningen.

Kentie, R., Senner, N. R., Hooijmeijer, J. C., Márquez-Ferrando, R., Figuerola, J., Masero, J. A., ... \& Piersma, T. (2016). Estimating the size of the Dutch breeding population of Continental Black- 
tailed Godwits from 2007-2015 using resighting data from spring staging sites. Ardea, 104(3), 213-226.

Kleijn, D., Berendse, F., Smit, R., Gilissen, N. (2001). Agri-environment schemes do not effectively protect biodiversity in Dutch agricultural landscapes. Nature, 413, 723-725.

Kleijn, D., Berendse, F., Verhulst, J., Roodbergen, M., Klok, C., van 't Veer, R. (2008). Ruimtelijke dynamiek van weidevogel-populaties in relatie tot de kwaliteit van de broedhabitat: Welke factoren beïnvloeden de vesteging van weidevogels? Ministerie van LNV, directie IFZ/Bedrijfsuitgeverij

Kleijn, D., Lamers, L. P. M., van Kats, R. J. M., Roelofs, J. G. M., \& van 't Veer, R. (2009). Ecologische randvoorwaarden voor weidevogelsoorten in het broedseizoen: resultaten van een pilotstudie in het Wormer-en Jisperveld (No. 2009/dk113). Directie Kennis, Ministerie van Landbouw, Natuur en Voedselkwaliteit.

Kleijn, D., Teunissen, W., Müskens, G., van Kats, R., Majoor, F., \& Hammers, M. (2014). Wintervoedselgewassen als sleutel tot het herstel van akkervogelpopulaties? . Wageningen: Alterra Wageningen UR, Sovon Vogelonderzoek Nederland.

Korpimaki, E. and Norrdahl, K., 1991. Numerical and functional responses of kestrels, short-eared owls, and long-eared owls to vole densities. Ecology, 72(3), pp.814-826.

Korpimäki, E. and Wiehn, J., 1998. Clutch size of kestrels: seasonal decline and experimental evidence for food limitation under fluctuating food conditions. Oikos, pp.259-272.

Kragten, S., K.B. Trimbos \& G.R. de Snoo, 2008. Breeding skylarks (Alauda arvensis) on organic and conventional arable farms in The Netherlands. Agriculture, Ecosystems and Environment 126: 163- 167

Kragten, S., Teunissen, W., \& Roodbergen, M. (2012). Onderzoek wijst uit: akkervogels gebaat bij overblijvend graan. Vogelnieuws, 20(2).

Kruk, M., Noordervliet, M.A.W., ter Keurs, W.J. (1997). Survival of black-tailed godwit chicks Limosa limosa in intensively exploited grassland areas in The Netherlands. Biological Conservation, 80, 127-133.

Kuiper MW, Ottens HJ, Cenin L, Schaffers AP, van Ruijven J, Koks BJ, Berendse F and de Snoo GR (2013) Field margins as foraging habitat for skylarks (Alauda arvensis) in the breeding season. Agriculture, Ecosystems \& Environment 170, 10-5. Ramsay and Houston 2003.

Kuiper, M. (2015). The value of field margins for farmland birds. Wageningen: Wageningen University.

Kuiper, M., \& Ottens, H. (2015, mei). Veldleeuwerik heeft meer nodig dan faunaranden. Vakblad Natuur, Bos, Landschap, 38-40.

Kwak, R., van Beusekom, R., Foppen, R., Louwe Kooijmans, J., \& de Pater, K. (2018). Bedreigde vogels in Nederland. Vogels van de Rode Lijst in hun leefgebied. Zeist: KNNV Uitgeverij.

Lambin, X., Bretagnolle, V. and Yoccoz, N.G., 2006. Vole population cycles in northern and southern Europe: is there a need for different explanations for single pattern? Journal of animal ecology, 75(2), pp.340-349.

Newton I, 1994. The role of nest sites in limiting the numbers of hole-nesting birds: a review. Biol Conserv 70:265-276.

Lopez-Anita, A., Ortiz-Santaliestra, M., Mougeot, F., \& Mateo, R. (2015). Imidacloprid-treated seed ingestion has lethal effect on adult partridges and reduces both breeding investment and offspring immunity. Environ. Res. (136), 97-107.

Maas, D., \& van der Arend, I. (2018). Tussenrapportage insectenonderzoek Interreg-project PARTRIDGE: Resultaten van het tweede jaar. Raamsdonksveer: Maasarend, Praktisch in ecologie.

Melman, T. C. P., van Doorn, A. M., Schotman, A. G. M., van der Zee, F. F., Blanken, H., Martens, S., ... \& Smidt, R. A. (2015). Nieuw stelsel agrarisch natuurbeheer: ex ante evaluatie provinciale natuurbeheerplannen (No. 2633). Alterra, Wageningen-UR.

Melman, D., Kleyheeg, E., Visser, T., Oosterveld, E., Roodbergen, M., Teunissen, W., \& Slier, T. (2020). Invloed greppel-plasdras op kuikenoverleving kievit (No. S2020/12). VBNE, Vereniging van Bos-en Natuurterreineigenaren.

Meeuwsen, H., \& Jochem, R. (2011). Openheid is een lastige maat. In N. Bakker, B. Jansen, Y. de Hilster, J. Tielens, K. Versluis, \& M. Woestenburg, Kennis in kaarten, Atlas van Wagenings onderzoek naar onze groene leefomgeving (pp. 40-41). Wageningen: Environmental Sciences Group, Wageningen UR.

Melman, Th.C.P., A.G.M. Schotman, H.A.M. Meeuwsen, R.A. Smidt, B. Vanmeulebrouk en H. Sierdsema, 2016. Ex-ante-evaluatie ANLb-2016 voor lerend beheer; Een eerste blik op de 
omvang en ruimtelijke kwaliteit van het beheer in het nieuwe stelsel. Wageningen, Wageningen Environmental Research, Rapport 2752

Melman, D., \& Sierdsema, H. (2017). Weidevogelscenario's: Mogelijkheden voor aanpak van verbetering van de weidevogelstand in Nederland (No. 2769). Wageningen Environmental Research.

Meynier F. (2004) Analyse des relations entre les densités de perdrix grises et les caractéristiques de I'habitat en plaine de grande culture à trois échelles spatiales, Mémoire de Diplôme d'Études Approfondies, Université Pierre et Marie Curie.

Moorcroft, D., Whittingham, M. J., Bradbury, R. B., \& Wilson, J. D. (2002). The selection of stubble fields by wintering granivorous birds reflects vegetation cover and food abundance. Journal of Applied Ecology, 39(3), 535-547.

Millot, F., Decors, A., Mastain, O., Quintaine, T., Berny, P., Vey, D., . . B Bro, E. (2017). Field evidence of bird poisonings by imidacloprid-treated seeds: a review of incidents reported by the French SAGIR network from 1995 to 2014. Environmental Science and Pollution Research, 24(6), 5469-5485.

Mücher, S., Kramer, H., van der Wijngaart, R., \& Huiskes, R. (2017). Ontwikkelen van een Remote Sensing monitoringssystematiek voor vegetatiestructuur. Pilotstudie: detectie verruiging Grijze Duinen (H2130) voor het Natura 2000-gebied Meijendel-Berkheide. Wageningen: Wageningen Environmental Research.

Newton, I. (2017). Farming and Birds. HarperCollins Publishers.

Ottens, H., Kuiper, M., \& Koks, B. (2013). Broedende Veldleeuweriken en natuurbeheer in agrarisch gebied. Oost Groningen in 2011 en 2012. Winschoten: Stichting Werkgroep Grauwe Kiekendief.

Panek, M. (1992). The effect of environmental factors on survival of grey partridge (Perdix perdix) chicks in Poland during 1987-89. Journal of Applied Ecology, 745-750.

Paz, A., Jareño, D., Arroyo, L., Viñuela, J., Arroyo, B., Mougeot, F., Luque-Larena, J.J. and Fargallo, J.A., 2013. Avian predators as a biological control system of common vole (Microtus arvalis) populations in north-western Spain: experimental set-up and preliminary results. Pest Management Science, 69(3), pp.444-450.

Perkins, A.J., Anderson, G. and Wilson, J.D., 2007. Seed food preferences of granivorous farmland passerines. Bird Study, 54(1), pp.46-53.

Petty, S.J., Anderson, D.I.K., Davison, M., Little, B., Sherratt, T.N., Thomas, C.J. and Lambin, X., 2003. The decline of Common Kestrels Falco tinnunculus in a forested area of northern England: the role of predation by Northern Goshawks Accipiter gentilis. Ibis, 145(3), pp.472-483.

Piha, M., Pakkala, T., \& Tiainen, J. (2003). Habitat preferences of the Skylark Alauda arvensis in southern Finland. Ornis Fennica, 80, 97-110.

Potts, G. (1986). The partridge: pesticides, predation and conservation. Collins.

Potts, G. R., \& Aebischer, N. J. (1991). Modelling the population dynamics of the grey partridge: conservation and management. Bird Population Studies. Relevance to Conservation and Management, 373-390.

Rands MRW (1985) Pesticide use on cereals and the survival of grey partridge chicks: a field experiment. Journal of Applied Ecology 22, 49-54. Sillanpää et al. 2010

Robinson, R. A., \& Sutherland, W. J. (2002). Post-war changes in arable farming and biodiversity in Great Britain. Journal of applied Ecology, 39(1), 157-176.

Ronnenberg, K., Strauß, E., \& Siebert, U. (2016). Crop diversity loss as primary cause of grey partridge and common pheasant decline in Lower Saxony, Germany. BMC ecology, 16(1), 39.

Rutz, C. and Bijlsma, R.G., 2006. Food-limitation in a generalist predator. Proceedings of the Royal Society B: Biological Sciences, 273(1597), pp.2069-2076.

Salamolard MA, Butet A, Leroux and Bretagnolle V, Responses of an avian predator to fluctuations in prey density at a temperate latitude. Ecology 81:2428-2441 (2000).

Šálek, M., Marhoul, P., Pintír, J., Kopecký, T., \& Slabý, L. (2004). Importance of unmanaged wasteland patches for the grey partridge Perdix perdix in suburban habitats. Acta Oecologica, 25(1-2), 23-33.

Schekkerman, H., Beintema, A.J. (2007). Abundance of invertebrates and foraging sucess of Blacktailed Godwit Limosa limosa chicks in relation to agricultural grassland management. Ardea, 95, 39-54.

Schekkerman, H., Teunissen, W.A., Oosterveld, E. (2008). Mortality of black-tailed godwit and nothern lapwing chicksin wet grasslands: roles of agriculture and predation. 
Schekkerman, H. (2008). Precocial problems: shorebird chick performance in relation to weather, farming and predation (S.n.).

Schekkerman, H., Teunissen, W., Oosterveld, E. (2005). Resultaatonderzoek Nederland Grutto-land: broedsucces van Grutto's in beheersmozaïeken in vergelijking met gangbaar agrarisch graslandgebruik. Wageningen, Alterra-document 1291, SOVON-onderzoeksrapport 2005/10, SOVON Vogelonderzoek Nederland.

Schekkerman H., Teunissen W. \& Oosterveld E. 2009. Mortality of black-tailed godwit Limosa limosa and northern lapwing Vanellus vanellus chicks in wet grasslands: influence of predation and agriculture. Journal of Ornithology, 150(1), pp. 133-145. Beek-Ubbergen.

Schippers, W., Bax, I., \& Gardeniers, M. (2015). Ontwikkelen van kruidenrijk grasland.

Simpson SJ, Sibly RM, Lee KP, Behmer ST and Raubenheimer D (2004) Optimal foraging when regulating intake of multiple nutrients. Animal Behaviour 68, 1299-311.

Siriwardena GM, Baillie SR, Crick HQP and Wilson JD (2000) The importance of variation in the breeding performance of seed-eating birds in determining their population trends on farmland. Journal of Applied Ecology 37, 128-48.

Siriwardena, G.M. and Stevens, D.K., 2004. Effects of habitat on the use of supplementary food by farmland birds in winter. Ibis, 146, pp.144-154.

Shrubb, M., 1980. Farming influences on the food and hunting of kestrels. Bird Study, 27(2), pp.109-115.

Sotherton, N. W. (1991). Conservation headlands: a practical combination of intensive cereal farming and conservation. The ecology of temperate cereal fields, 373-397.

Sotherton, N. W. (1998). Land use changes and the decline of farmland wildlife: an appraisal of the set-aside approach. Biological Conservation, 83(3), 259-268.

Tattersall FH, MacDonald DW, Manley WJ, Gates S, Feber R, Hart BJ (1997) Small mammals on oneyear set-aside. Acta Theriol 42:329-334

Taylor RL, Maxwell BD and Boik RJ (2006) Indirect effects of herbicides on bird food resources and beneficial arthropods. Agriculture, Ecosystems \& Environment 116, 157-64.

Tkadlec, E. and Stenseth, N.C., 2001. A new geographical gradient in vole population dynamics. Proceedings of the Royal Society of London. Series B: Biological Sciences, 268(1476), pp.1547-1552.

Teunissen W., Schekkerman H. \& Willems F. 2005. Predatie bij weidevogels. Op zoek naar de mogelijke effecten van predatie op de weidevogelstand. Sovon onderzoeksrapport 2005/11. Sovon Vogelonderzoek Nederland, Beek- Ubbergen.

Teunissen, W.A. (2007). Afname van weidevogels versnelt sinds eeuwwisseling. SOVON-Nieuws, 20, 15-17.

Teunissen, W., Klok, C., Kleijn, D., Schekkerman, H. (2008). Factoren die de overleving van weidevogelkuikens beïnvloeden. Ministerie van LNV, directie IFZ/Bedrijfsuitgeverij.

Tinberger L. (1946). De sperwer als roofvijand van zangvogels. Ardea 34: 1-213.

Tinbergen JM (1980) Foraging decisions in starlings Sturnus vulgaris L. PhD thesis, Rijksuniversiteit Groningen, the Netherlands.

Toepfer S and Stubbe M (2001) Territory density of the Skylark (Alauda arvensis) in relation to field vegetation in central germany. Journal für Ornithologie 142, 184-94.

Valkama, J.A.R.I. and Korpimäki, E.R.K.K.I., 1999. Nestbox characteristics, habitat quality and reproductive success of Eurasian Kestrels. Bird Study, 46(1), pp.81-88.

Van der Zande, A.N. and Verstrael, T.J., 1985. Impacts of outdoor recreation upon nest-site choice and breeding success of the Kestrel. Ardea, 73, pp.90-99.

Vandewaerde, H. (2018). Plan Kiekendief: nieuw momentum voor akkervogelbescherming in Vlaanderen. Themanummer akkervogels. Natuur.oriolus, 84(3), 101-106.

Van Emmerik, W.A.M., \& H.W. de Nie, 2006. De zoetwatervissen van Nederland. Ecologisch bekeken. Vereniging Sportvisserij Nederland, Bilthoven.

Verhulst, J., Melman, T.C.P., de Snoo, G.R. (2008). Voedselaanbod voor gruttokuikens in de Hollandse veenweidegebieden. Wageningen, Alterra, Alterra-rapport 1668

Vickery J, Carter N and Fuller RJ (2002) The potential value of managed cereal field margins as foraging habitats for farmland birds in the UK. Agriculture, Ecosystems \& Environment 89, 41-52.

Viitala, J., Korplmäki, E., Palokangas, P. and Koivula, M., 1995. Attraction of kestrels to vole scent marks visible in ultraviolet light. Nature, 373(6513), pp.425-427. 
Village, A., 1982. The home range and density of kestrels in relation to vole abundance. The Journal of Animal Ecology, pp.413-428.

Village, A., 2010. The kestrel. Bloomsbury Publishing.

Vliet van der, R.E., Schuller E. \& Wassen M.J. (2008). Avian predators in a meadow landscape: consequences of their occurrence for breeding open-area birds. Journal of Avian Biology 39: 523-529.

Wiersma, P., Luske, B., Bos, J., Hakkert, J., Ottens, H., Postma, M., . . . Zanen, M. (2019). Vogelakkers. Het effect op de biodiversiteit en de landbouwkundige inpasbaarheid. Werkgroep Grauwe Kiekendief, Louis Bolk Instituut, Vogelbescherming Nederland.

Wilson, J.D., J. Evans, S.J. Browne \& J.R. King, 1997. Territory distribution and breeding success of skylarks Alauda arvensis on organic and intensive farmland in southern England. Journal of Applied Ecology 34: 1462-1478

Wilson JD, Morris AJ, Arroyo BE, Clark SC and Bradbury RB (1999) A review of the abundance and diversity of invertebrate and plant foods of granivorous birds in northern Europe in relation to agricultural change. Agriculture, Ecosystems \& Environment 75, 13-30. 


\section{Bijlage 1 Totstandkoming kaartbeelden}

\section{B1.1 Openheid landschap}

Het viewscape model kan worden gebruikt om de openheid van het landschap te berekenen en op kaart weer te geven (Meeuwsen en Jochem, 2011). In dit model worden opgaande structuren zoals bomenrijen en bebouwing beschouwd als ondoorzichtbare elementen. Het model rekent voor 4,5 miljoen locaties in Nederland uit wat de zichtafstand is. Dit wordt gedaan door vanaf de locatie in kwestie zichtlijnen te trekken in alle richtingen (360 graden) (zie onderstaande figuur).

De lengte van de zichtlijn is afhankelijk van de aanwezigheid van opgaande structuren. Daar waar opgaande structuren afwezig zijn, is de zichtlijn lang (tot maximaal $1500 \mathrm{~m}$ ). Daar waar opgaande structuren aanwezig zijn, is de zichtlijn korter.

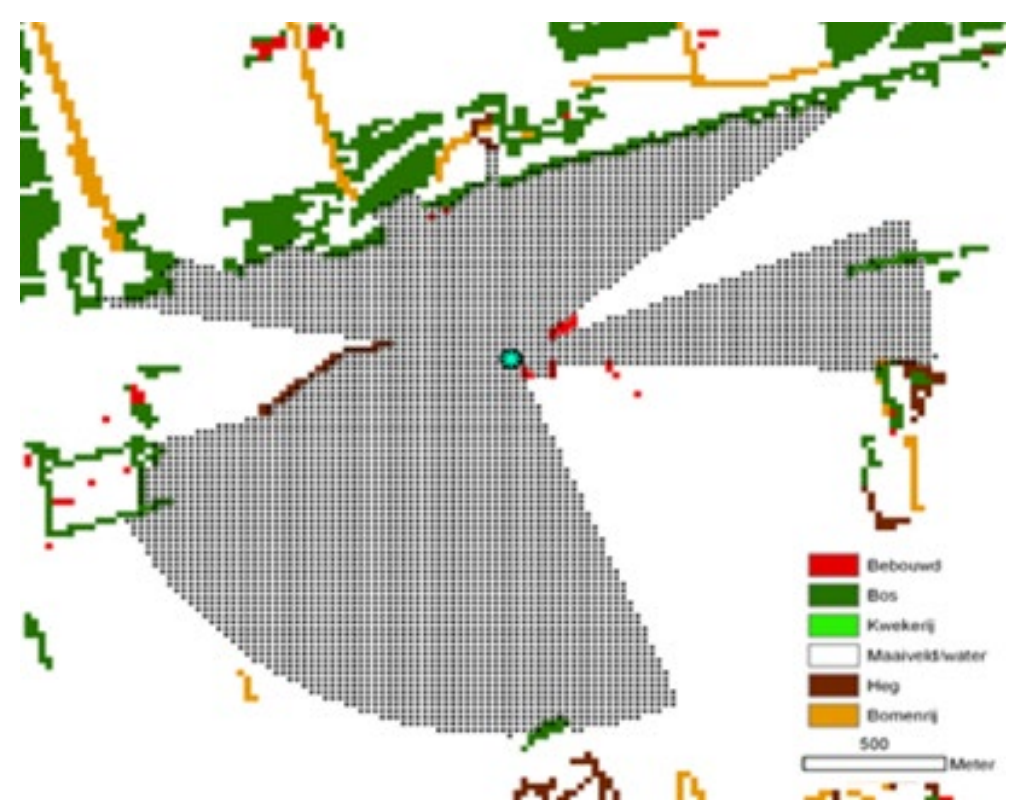

Figuur B1.1 Berekening openheid vanuit 1 vast punt. Grijze arcering toont de lengte van de zichtlijnen.

De openheid van de locatie kan uiteindelijk worden bepaald door de gemiddelde lengte van de zichtlijnen in alle richtingen te nemen. Deze aanpak resulteert in een kaartbeeld waarop voor iedere cel van 25 bij 25 m de openheid kan worden afgelezen (zie onderstaand kaartbeeld). Dit kaartbeeld kan worden gebruikt om de gemiddelde openheid van een gebied te berekenen. 


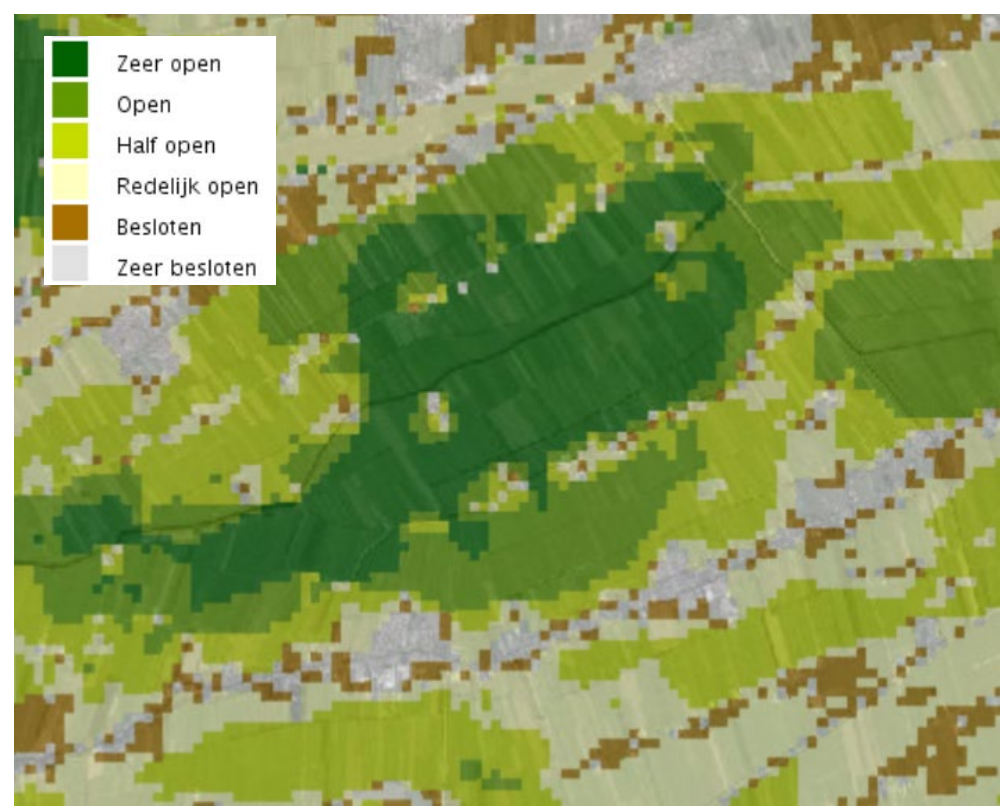

Figuur B1.2 Kaartbeeld openheid landschap. De absolute waarden in meters zijn hier doorvertaald naar klassen.

\section{B1.2 Verstorende elementen}

Bij het ontwikkelen van de verstoringskaart is rekening gehouden met de volgende aspecten:

- De mate waarin een verstorend effect optreedt, is afhankelijk van de verstoringsbron (zo heeft een bomenrij een 'groter' verstorend effect dan een fietspad, mede omdat het verstorende effect van een bomenrij constant is. Dit in tegenstelling tot bijvoorbeeld het verstorende effect van een fietspad, dat in de tijd varieert (als gevolg van de variërende drukte op het fietspad).

- Het verstorende effect neemt af naarmate de afstand ten opzichte van de verstorende bron toeneemt.

- Het verstorende effect differentieert per soort.

Het verstorende effect is ingedeeld in vijf klassen. In onderstaande tabel (Tabel B1.1) is weergegeven hoe deze klassen zijn toegekend aan de verschillende verstoringsbronnen, per afstand ten opzichte van deze verstoringsbron.

Tabel B1.1 De mate van verstoring per verstoringsbron, per afstand t.o.v. deze verstorende bron. Betekenis getallen: $0=$ niet verstoord, van 1 tot $5=$ van zeer licht verstoord tot zeer zwaar verstoord. Voor onderbouwing van de verstoringsafstanden, zie: Teunissen et al., 2012, Bruinzeel \& Schotman, 2011 en Sierdesma et al., 2013.

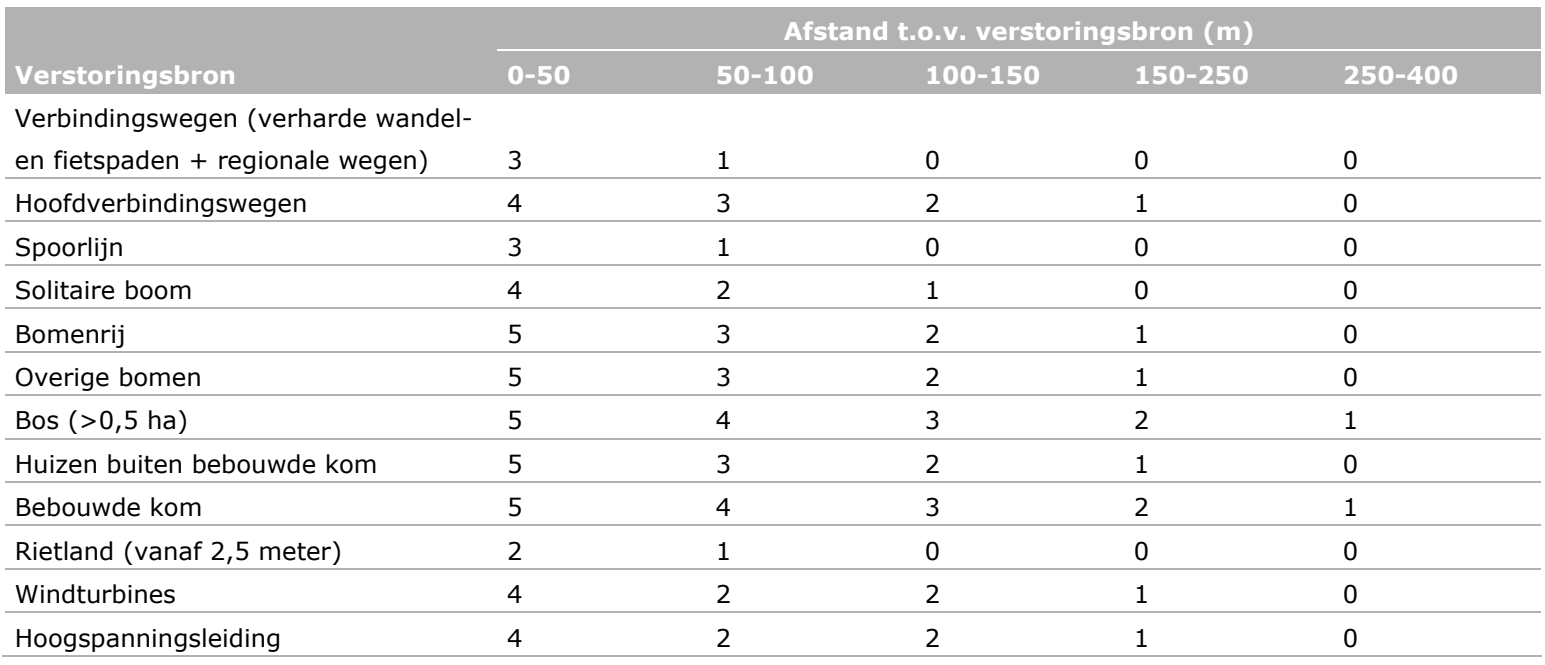




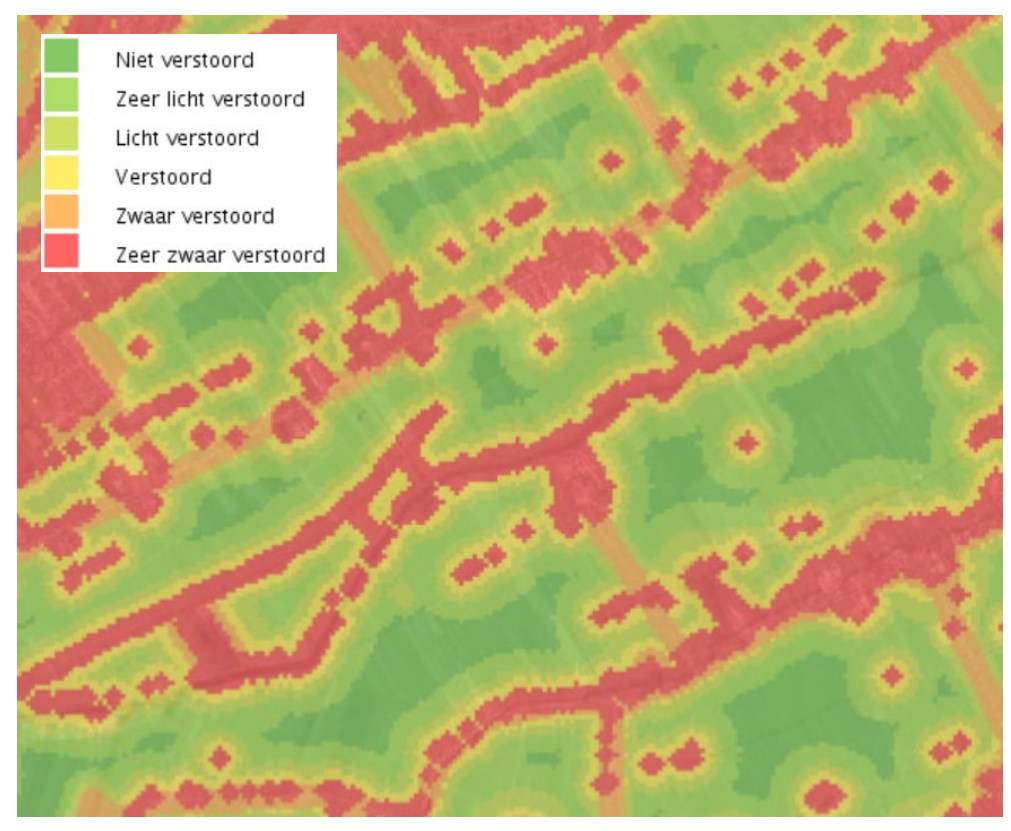

Figuur B1.3 Verstorende elementen. Dit kaartbeeld toont de mate van verstoring op basis van de bron van verstoring en de afstand ten opzichte van deze bron.

\section{B1.3 Bodemvochtigheid}

De bodemvochtigheid is in drie stappen berekend:

1. Berekenen drooglegging: de drooglegging is berekend door de maaiveldhoogte (op basis van het Algemeen Hoogtebestand Nederland) te vergelijken met het vigerende peilbesluit. Hierbij is gebruikgemaakt van het waterpeil in de winter, omdat uit onderzoek in Noord-Holland is gebleken (Schotman et al., 2008) dat de drooglegging in de winter een belangrijke relatie heeft met de trend van weidevogels en het voorkomen van natte en vochtige graslanden tijdens het broedseizoen.

2. Vertalen van de drooglegging in centimeters naar klasse-indeling bodemvochtigheid, rekening houdend met het bodemtype: het bodemtype is van grote invloed op de relatie tussen de drooglegging en de bodemvochtigheid. Zo leidt een drooglegging van $35 \mathrm{~cm}$ op veengrond tot een redelijk vochtige bodem, terwijl een drooglegging van $35 \mathrm{~cm}$ op zandgrond leidt tot een relatief droge bodem. Om deze reden is bij het vertalen van de feitelijke drooglegging (in centimeters) naar de klasse-indeling van de bodemvochtigheid (nat, vochtig, matig vochtig, droog) rekening gehouden met het bodemtype. Dit is gedaan door de klassegrenzen per bodemtype te differentiëren (zie Tabel B1.3). De klassegrenzen en differentiatie per bodemtype zijn gebaseerd op onderzoek van Teunissen et al. (2012). Uit dit onderzoek kunnen de droogleggingswaarde per bodemtype worden afgelezen waarop $75 \%$ van de populaties een negatieve/positieve ontwikkeling kent.

3. Rekening houden met kwel en wegzijging: Het optreden van kwel en wegzijging kan de bodemvochtigheid beïnvloeden. Om deze reden is op locaties waar kwel/wegzijging optreedt de drooglegging gecorrigeerd (zie onderstaande tabel). Voorbeeld: de drooglegging op locatie $X$ (veenbodem) is $40 \mathrm{~cm}$. Locatie $X$ wordt daarom ingedeeld in klasse 3: matig vochtig. Echter, doordat op deze locatie zeer sterke kwel optreedt (>0,5 mm/etm), wordt de drooglegging van locatie $X$ verkleind met $10 \mathrm{~cm}$. De drooglegging is daardoor verkleind tot $30 \mathrm{~cm}$, waardoor locatie $X$ wordt heringedeeld in klasse 2: vochtig. De grootte van de correctie is gebaseerd op de relatie tussen kweldruk en het effect op de bodemvochtigheid (Jansen e.a., 2009) (zie Tabel B1.2). 
Tabel B1.2 Correctie van drooglegging (laatste kolom) op basis van de kweldruk (eerste drie kolommen). Gebaseerd op Jansen e.a. (2009).

\begin{tabular}{lllll}
$\#$ & Categorie & Ondergrens $(\mathrm{mm} / \mathrm{dag})$ & Bovengrens $(\mathrm{mm} / \mathrm{dag})$ & Effect op drooglegging \\
\hline 1 & Zeer sterke kwel & 1 & 2 & $15(=\mathrm{vernatting})$ \\
\hline 2 & Sterke kwel & 0,5 & 1 & 8 \\
\hline 3 & Zwakke kwel & 0,25 & 0,5 & 5 \\
\hline 4 & Zeer zwakke kwel & 0,05 & 0,25 & 2 \\
\hline 5 & Neutraal & $-0,05$ & 0,05 & 0 \\
\hline 6 & Zeer Zwakke wegzijging & $-0,25$ & $-0,05$ & +1 \\
\hline 7 & Zwakke wegzijging & $-0,5$ & $-0,25$ & +3 \\
\hline 8 & Sterke wegzijging & -1 & $-0,5$ & +5 \\
\hline 9 & Zeer sterke wegzijging & -2 & -1 & $+8(=v e r d r o g i n g)$ \\
\hline
\end{tabular}

\section{Tabel B1.3 Klassegrenzen drooglegging per bodemtype}

\begin{tabular}{|c|c|c|}
\hline$\#$ & Klasse & Klassegrenzen \\
\hline 1 & Nat grasland & $\begin{array}{l}\text { Drooglegging kleiner dan } 20 \text { (veen), } 30 \text { (klei op veen), } 40 \text { (klei), } 15 \text { (zand) cm } \\
\text { onder maaiveld. }\end{array}$ \\
\hline 3 & Matig vochtig grasland & $\begin{array}{l}\text { Drooglegging tussen 35-50 (veen), 50-60 (klei op veen), 60-70 (klei), } \\
25-35 \text { (zand) cm onder maaiveld. }\end{array}$ \\
\hline 4 & Droog grasland & $\begin{array}{l}\text { Drooglegging groter dan } 50 \text { (veen), } 60 \text { (klei op veen), } 70 \text { (klei), } 35 \text { (zand) cm } \\
\text { onder maaiveld. }\end{array}$ \\
\hline
\end{tabular}

Bovenstaande aanpak leidt tot onderstaand kaartbeeld.

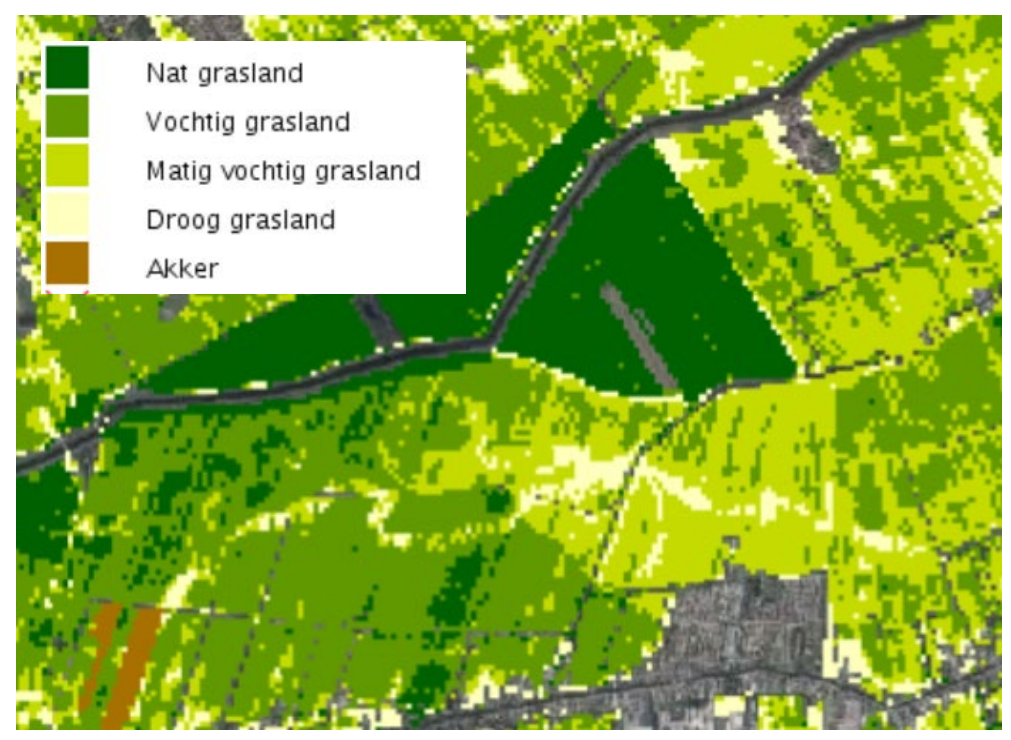

Figuur B1.4 Bodemvochtigheid

\section{B1.4 Gewasdiversiteit}

De gewasdiversiteit kan worden berekend op basis van gegevens zoals beschikbaar in het BRPbestand (basisregistratie percelen). In dit bestand wordt op perceelniveau het type gewas doorgegeven. Dit bestand kan binnen GIS omgezet worden naar een rasterbestand. Vervolgens kan voor iedere cel van 25 bij 25 m worden berekend hoeveel verschillende soorten gewassen er binnen een nader te bepalen radius aanwezig zijn. 


\section{B1.5 Perceelgrootte}

De perceelgrootte van het agrarisch landschap kan worden berekend op basis van gegevens zoals beschikbaar in het BRP-bestand (basisregistratie percelen). Hierbij wordt simpelweg gebruikgemaakt van de grootte van het perceel in hectares. Deze gegevens kunnen worden doorvertaald naar een raster met een detailniveau van 25 bij $25 \mathrm{~m}$. Dit maakt het mogelijk om de gemiddelde perceelgrootte binnen een gebied te berekenen.

\section{B1.6 Integratie: gewastypen, intensief/extensief grasland \& seminatuurlijke vegetaties (ANLb)}

Voor enkele analyses is het relevant om over een zo compleet mogelijke habitatkaart te beschikken. Het gaat daarbij primair om de gewastypen, die kunnen worden afgeleid uit het BRP-bestand (Basis Registratie Percelen). Grasland wordt in dit bestand onderverdeeld in blijvend grasland en tijdelijk grasland. Het is echter wenselijk om blijvend grasland verder op te splitsen naar de intensiteit van gebruik: van zeer intensief gebruikt grasland tot extensief gebruikte graslanden. Dit onderscheid kan worden bewerkstelligd door NDVI-beelden hierin te integreren. Vervolgens dienen vormen van agrarisch natuurbeheer te worden geïntegreerd. Denk daarbij aan braakliggend bouwland, kruidenrijke akkerranden en dergelijke. 
Wageningen Environmental Research Postbus 47

6700 AA Wageningen

T 0317480700

www.wur.nl/environmental-research

Wageningen Environmental Research Rapport 3018

ISSN 1566-7197
De missie van Wageningen University \& Research is 'To explore the potential of nature to improve the quality of life'. Binnen Wageningen University \& Research bundelen Wageningen University en gespecialiseerde onderzoeksinstituten van Stichting Wageningen Research hun krachten om bij te dragen aan de oplossing van belangrijke vragen in het domein van gezonde voeding en leefomgeving. Met ongeveer 30 vestigingen, 5.000 medewerkers en 12.000 studenten behoort Wageningen University \& Research wereldwijd tot de aansprekende kennisinstellingen binnen haar domein. De integrale benadering van de vraagstukken en de samenwerking tussen verschillende disciplines vormen het hart van de unieke Wageningen aanpak. 



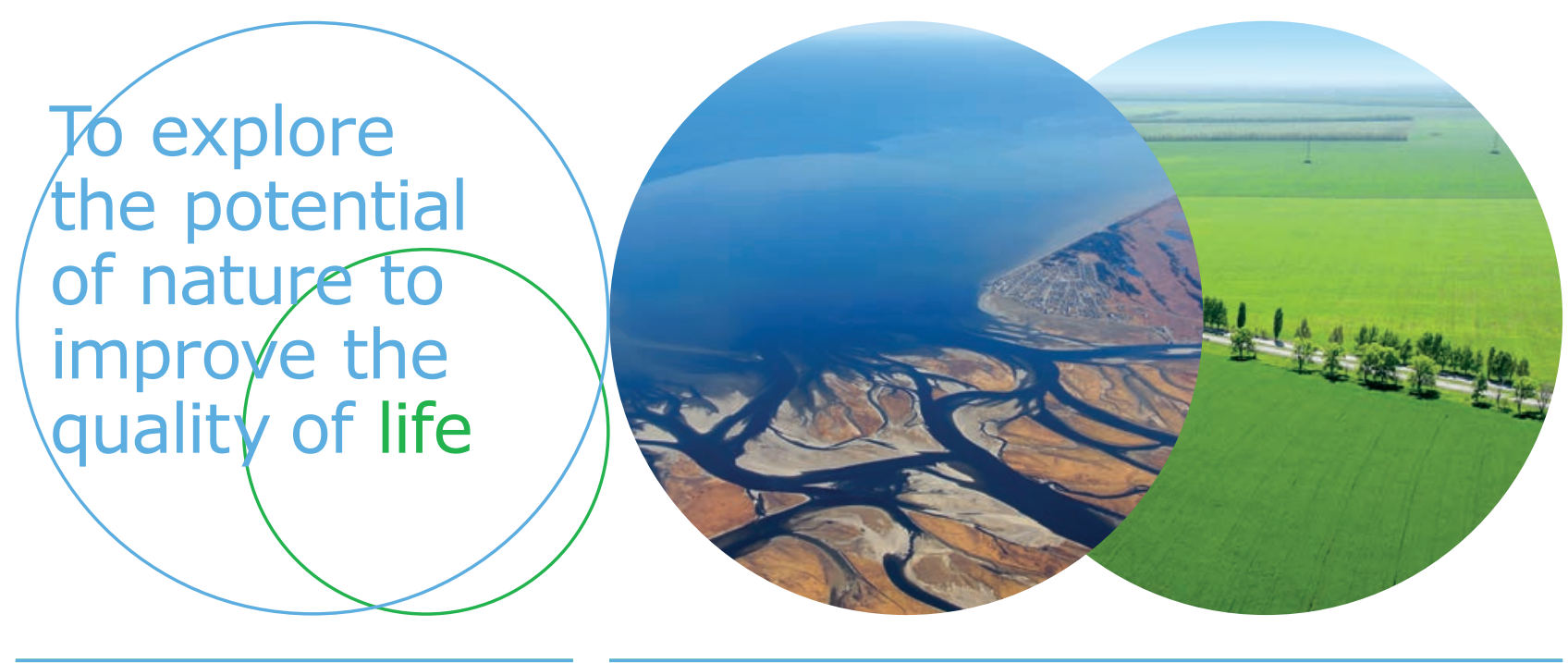

Wageningen Environmental Research Postbus 47

$6700 \mathrm{AB}$ Wageningen

T 317480700

www.wur.nl/environmental-research

Rapport 3018

ISSN 1566-7197
De missie van Wageningen University \& Research is 'To explore the potential of nature to improve the quality of life'. Binnen Wageningen University \& Research bundelen Wageningen University en gespecialiseerde onderzoeksinstituten van Stichting Wageningen Research hun krachten om bij te dragen aan de oplossing van belangrijke vragen in het domein van gezonde voeding en leefomgeving. Met ongeveer 30 vestigingen, 5.000 medewerkers en 12.000 studenten behoort Wageningen University \& Research wereldwijd tot de aansprekende kennisinstellingen binnen haar domein. De integrale benadering van de vraagstukken en de samenwerking tussen verschillende disciplines vormen het hart van de unieke Wageningen aanpak. 